\title{
MASTER
}

\section{Report on the Design and Operation of a Full-Scale Anaerobic Dairy Manure Digester}

\section{Final Report}

\author{
Elizabeth Coppinger \\ Jack Brautigam \\ John Lenart \\ David Baylon \\ Ecotope Group \\ Seattle, Washington
}

Prepared Under

Department of Energy

Subcontract No. EG-77-C-06-1016

for the
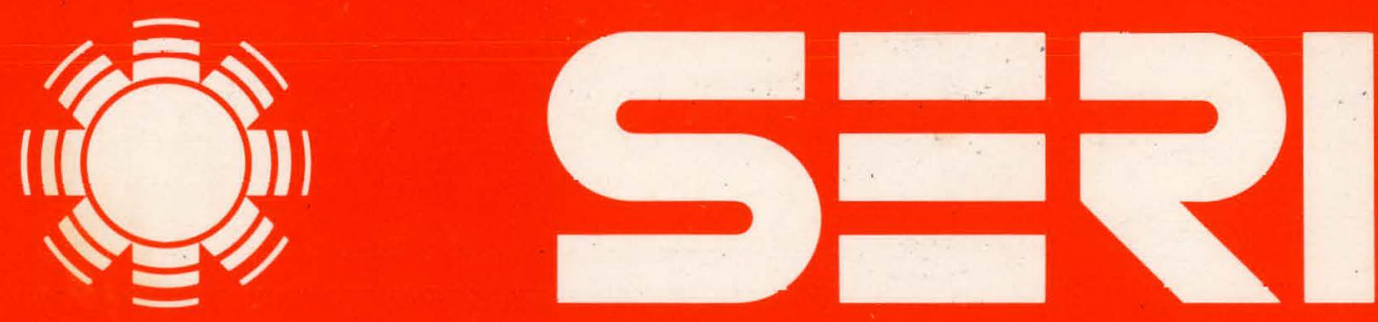

Solar Energy Research Institute

A Division of Midwest Research Institute

1536 Cole Boulevard

Golden, Colorado 80401

Operated for the

U.S. Department of Energy under Contract No. EG-77-C-01-4042

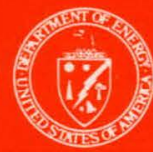




\section{DISCLAIMER}

This report was prepared as an account of work sponsored by an agency of the United States Government. Neither the United States Government nor any agency Thereof, nor any of their employees, makes any warranty, express or implied, or assumes any legal liability or responsibility for the accuracy, completeness, or usefulness of any information, apparatus, product, or process disclosed, or represents that its use would not infringe privately owned rights. Reference herein to any specific commercial product, process, or service by trade name, trademark, manufacturer, or otherwise does not necessarily constitute or imply its endorsement, recommendation, or favoring by the United States Government or any agency thereof. The views and opinions of authors expressed herein do not necessarily state or reflect those of the United States Government or any agency thereof. 


\section{DISCLAIMER}

Portions of this document may be illegible in electronic image products. Images are produced from the best available original document. 
Printed in the United States of America

Available from:

National Technical Information Service

U.S. Department of Commerce

5285 Port Royal Road

Springfleld, VA 22161

Price:

Microfiche $\$ 3.00$

Printed Copy $\$ 6,00$

\section{NOTICE}

This report was prepared as an account of work sponsored by the United States Government. Neither the United States nor the United States Department of Energy, nor any of their employees, nor any of their contractors, subcontractors, or their employees, makes any warranty, express or implied, or assumes any legal liability or responsibility for the accuracy, completeness or usefulness of any information, apparatus, product or process disclosed, or represents that its use would not infringe privately owned rights. 
SER I /TR-312-471

UC CATEGORY: UC-61

\section{MASTER}

REPORT ON THE DESIGN AND OPERATION OF A FULL-SCALE ANAEROBIC DAIRY

MANURE DIGESTER

FINAL REPORT

DECEMBER 1979

EL I ZABETH COPP INGER

JACK BRAUTIGAM

JOHN LENART

DAVID BAYLON

ECOTOPE GROUP

SEATTLE, WASHINGTON

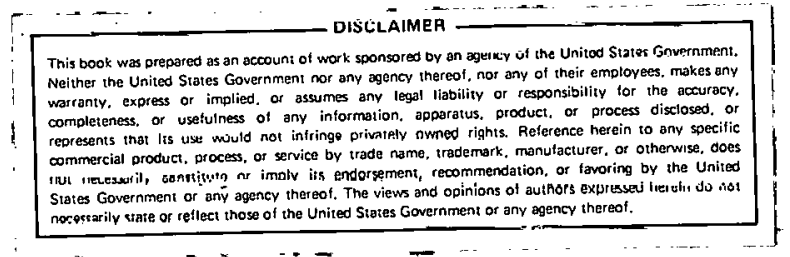

PREPARED UNDER DOE SUBCONTRACT

NO. EG-77-C-06-1016

FOR THE

\section{Solar Energy Research Institute}

1536 Cole Boulevard

Golden, Colorado 80401

A Division of Midwest Research Institute

Prepared for the

U.S. Department of Energy

Contract No. EG. $77 \cdot \mathrm{C} \cdot 01 \cdot 4042$

PROJECT MANAGER

DAN JANTZEN 


\section{THIS PAGE \\ WAS INTENTIONALLY \\ LEFT BLANK}




\section{FOREWORD}

This report details two years of operating experience with a 200-cow-unit dairy manure digester. The experience gained with this unit clearly indicates that the original digester design, based on principles developed for sewage treatment plants, was not optimal for a dairy system. A number of modifications were made as operating experience indicated the changes required to improve the system. The result is a much improved understanding of the requirements of a dairy manure digester for American farms, and the potential for producing cost-competitive energy from a former source of waste.

The contract for this work was issued in 1977 by the Department of Energy as contract EG-77-C-06-1016. In the last months of the project, the project management responsibilities were transferred from DOE to the Solar Energy Research Institute, and thus this report is issued as a SERI report.

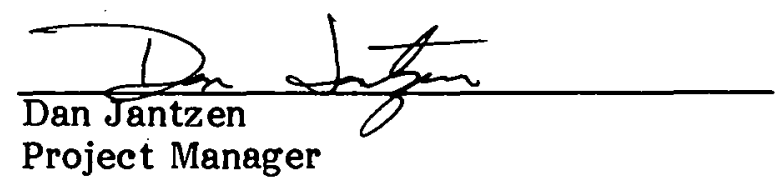


THIS PAGE

\section{WAS INTENTIONALLY LEFT BLANK}


TABLE OF CONTENTS

Chapter

Page

Abstract

vii

List of Figures

ix

List of Tables

$x i$

Summary

Conclusions

I. Introduction 5

II. System Description 7

A. Introduction 7

B. Design ' 8

C. Tanks 9

D. Manure Handling System 9

E. Digester Heating and Mixing System 10

F. Gas Handling System 12

III. Operational Experience 14

A. Tanks and Insulation 14

B. Manure Handling 18

C. Digester Heating and Mixing 24

D. Gas Handling and Utilization 39

E. Start-up and Shutdown 46

IV. Biological Performance 49

A. Laboratory Testing 49

B. System Start-up 49

C. Gas Production and Digestion Performance . 51

D. System Shutdown 54

E. Biological Stability 5

V. Net Energy 57

A. Overview $\quad 57$

B. Gas Production $\quad 57$

C. Energy Inputs $\quad 57$

D. Net Energy Evaluation 58

VI. Economics 63

$\begin{array}{ll}\text { Appendix } 1 & 72\end{array}$

$\begin{array}{lll}\text { Appendix } 2 & 71\end{array}$ 
THIS PAGE

\section{WAS INTENTIONALLY \\ LEFT BLANK}


ABSTRACT

A full-scale anaerobic digester on the Monroe State Dairy Farm was operated and monitored for 24 months with funding provided by the United States Department of Energy, Fuels from Biomass Systems Branch. During the period of operation, operating parameters were varied and the impact of those changes is described.

Operational experiences and system component performance are discussed. Internal digester mixing equipment was found to be unnecessary, and data supporting this conclusion are given. An influent/effluent heat exchanger was installed and tested, and results of the tests are included. Recommendations for digester design and operation are presented.

Biological stability was monitored, and test results are given. Gas production rates and system net energy are analyzed. The economics of anaerobic digestion are evaluated based on various financing options, design scales, and expected benefits. Under many circumstances digesters are feasible today, and a means of analysis is given. 
THIS PAGE

WAS INTENTIONALLY

LEFT BLANK 
LIST OF FIGURES

Number

$\underline{\text { Page }}$

$1 \quad$ Schematic of Monroe Digester System 7

2 Site Plan for Methane Digester

$3 \quad$ Manure Handling System 10

$4 \quad$ Digester Mixing and Heating System 11

5. Cross-Section of Digester Heating and Mixing System 11

$6 \quad$ Gas Handling System 12

$7 \quad$ Gas Handling Equipment Schematic 13

8 Diagram of Test Apparatus $\quad 22$

$9 \quad$ Relationship between Pressure Loss and \%TS 23

10 . Boiler Heating System 26

11 Waukesha Coolant used for Digester Heating 26

12 Digester Heating System 27

13 Influent/Effluent Counterflow Heat Exchanger 28

14 Temperature Probe Readings 33

$15 \quad$ Temperature Probe Readings $\quad 34$

$16 \quad$ Temperature Probe Readings $\quad 37$

17 Temperature Probe Readings $\quad 37$

18 Temperature Probe Readings 38

19 Gas Handling System Schematic 39

20 Conversion Efficiency for Electrical Generation 43

21 Start-Up 50

22 Operating Data for Methane Digester . 53

23 Digester Ferformance Durilly Syslem Shutdown 55

24 Relationship of Gas Production and Loading Rate . 60

25 Electricity Consumption $\quad 60$

$26 \quad$ Net Energy 61

27 Cost Comparison of Various Fuels 70

28 Cost of Energy irs \$/Gigajoule 71 
THIS PAGE

\section{WAS INTENTIONALLY LEFT BLANK}


$1 \quad \% T S$ of Digester Contents in Mixing Studies, 1978

$2 \quad$ Monroe Digester Performance, October 1977 to August 197952

3 Gas Production and Boiler Consumption 59

$4 \quad$ Life Cycle Așumptions

$5 \quad$ Energy Outputs, Capital, Operation, and Maintenance 66

6 Cost of Gas for Farm Scale Anaerobic Digestion 68

$7 \quad$ Cost of Electricity for Farm Scale Digestion Systems . 69

in $\$$ per Kilowatt Hour 
SUMMARY

Ecotope Group has been under contract to the United States Department of Energy to operate a full-scale anaerobic digester for dairy cow manure at the State Reformatory Honor Farm near Monroe, Washington. The system was designed by Parametrix Engineering and Ecotope Group under contract with the Washington State Department of Social and Health Services (DSHS) and the State Department of Ecology (ECOLOGY).

The Monroe digester provided a reliable source of fuel gas over the 23 months of operation. The plant evolved during the two years of work, and is much different from the original plan. It is more simple, easier to operate, and also more energy efficient. The improvements for the most part were made by eliminating equipment and operations that were found to be unnecessary. These improvements have contributed to making the technology a feasible alternative for energy production.

The most difficult problem of operating a full-scale digester is mixing and moving the manure. Three types of pumps were tried: centrifugal, diaphragm, and progressive cavity. The centrifugal pump proved to be the most reliable for our substrate that included bedding chips and an incredible assortment of debris. This pump performed well with manure below $10 \%$ TS, was marginally effective with $10-12 \%$ TS manure, and would not pump manure above $12 \%$ TS. The other pumps would have worked better at high solids levels if so much foreign material had not been in the substrate. Digester operation was simplified significantly by using gravity-flow rather than a pump to move effluent from the digester to the storage lagoon. Clogging was a consistent problem in both influent and effluent pipes, and methods to prevent clogging were developed.

The digester design included a gas recirculation mixer based on sewage treatment plant experience. This mixer, a Rootes blower, was expensive, required considerable electrical energy, and required regular maintenance. Use of the mixer was progressively reduced from continuous operation to no operation at all. Experiments showed that sufficient mixing occurs naturally in the tank, due to natural convection currents and gas bubbling. No reduction in gas production or operational problems resulted from the elimination of gas recirculation mixing. The electrical energy savings were about 60 GJ per month, which represents about $90 \%$ of the original electricity demand of the system and a significant portion of the net energy yield. Thus savings in capital cost, operating cost, and maintenance cost for dairy 
manure digesters can be achieved by simply eliminating in-tank mixing from the design.

The biological stability. of digesting dairy manure was impressive. There was no need to alter the naturally occurring biological conditions throughout the 23 months of operation. The contents of the digester were stressed by subjection to periods without substrate loading during equipment outages, and to a fourteen day period without heating or loading during shutdown. In all cases, gas production recovered quickly upon resumption of loading and heating.

The gas handling system functioned reliably after an initial period of troubleshooting. The majority of gas handling problems were due to the high moisture content of the gas, and to freezing of water condensate in gas lines during winter. The problems were overcome by installing an adequate number of drip traps and insulating outside gas lines to prevent freezing. With regular maintenance, operation of the gas handling system was trouble-free.

The potential annual total energy production of the system is about $1800 \mathrm{GJ}$. The potential annual net energy yield is about 950-1000 GJ. Further improvements in net energy would be possible by improving component efficiencies. The influent/effluent shell and tube heat exchanger failed to recover effluent heat as expected. Lack of forced convective currents in the flowing manure, and the tendency of the manure to flow in stratifications inhibited heat transfer in the flowing streams. The prospects for a successful shell and cube influent/ effluent heat exchanger design are not good, and other methods of effluent heat recovery are probably more promising.

'The economics of dairy manure digester systems similar to the Monroe facility have been analyzed based on various financing options, design scales, energy outputs, and expected benefits. These analyses show that owner-financed systems can produce energy at less than the present cost of propane or fuel oil. If farm labor costs are discounted by assuming no additional hired labor is required, energy can be produced at costs less than the cost of natural gas in many areas of the country. If electricity is the energy output, all farmer-financed systems analyzed can produce electricity for less than $\$ .055 / \mathrm{KWH}$. The analyses show that energy produced by anaerobic digestion is competitive with many present energy costs. 
Anaerobic digestion of manure has often been considered of minor importance in light of the national energy need. Widespread application, however, could make farms and feedlots significantly less dependent on fossil fuels and make them net energy producers. This step would make agriculture less vulnerable to the uncertainties of energy supply and rapidly inflating energy costs. 
CONCLUSIONS

The following is concluded after two years of digester operation:

1. A full-scale dairy manure digester is capable of providing a consistent and reliable source of fuel.

2. Dairy manure digesters develop stable microbiological populations, and no alteration of naturally occurring biological parameters is required.

3. In-tank mixing is not necessary for full-scale, rigid tank, dairy manure digesters. Natural mixing from convection currents and gas bubbling is adequate, provided the $\%$ TS in the tank remains above the point at which scum formation ceases to be a problem.

4. Influent/effluent shell and tube heat exchangers are not a good prospect for efficient effluent heat recovery with dairy manure digesters.

5. Energy produced by farmer-financed dairy manure digesters is competitive in cost with other energy sources, especially propane and fuel oil. 


\section{INTRODUCTION}

The face of agriculture in the United States has altered dramatically since the end of World War II. Technological advances, fueled by inexpensive energy, have revolutionized agriculture in this country and made it the most technologically advanced and productive in the world. Like other industries, agriculture has moved toward centralization to improve productivity and profits. In livestock operations, larger numbers of animals are being concentrated on smaller areas of land. While confined herds have improved productivity and eased management problems, they are completely dependent on mechanical systems to deliver food and remove manure.

Although these developments have increased profits during the past two decades, recent changes in water pollution legislation and the cost of energy have resulted in increasing economic pressure on farmers. With the passage of the Federal Water Pollution Control Act, and the subsequent regulations concerning non-point source pollution, farmers are being required to deal with the wastes they produce. Although regulations now seek voluntary compliance with the recommended manure management practices, agencies will be given enforcement powers in 1981 to insure that farms do have adequate manure handling systems.

The pressures concerning waste management are added to the rising costs of fuel and fertilizer. The increasing cost of inorganic fertilizer is causing many farmers to reconsider the use of animal manures to replace fertilizer now being purchased. The rise in the cost of fuel is probably the. most dramatic and unanticipated problem facing the farmer. Not only have inflation and fuel costs escàlated at a rate unforseen five years ago, but farmers are now beginning to fear fuel shortages. In some areas, the diesel shortages of the summer of 1979 are perceived as a precursor of serious future shortages. The idea of energy independence is gaining wide appeal among farmers.

As a result of these economic and legislative changes, there is a great deal of interest in anaerobic digestion. Anaerobic digestion has moved from being a generally unknown concept to one that is commonly recognized, even if not fully understood. Many farmers are interested in building systems, and many more are looking for information about them.

The economics of digestion for farm scale systems is improving, notably due to rising fuel costs. Funds are becoming available for the construction of digester.s, 
both as energy producers and as components of improved manure handling systems. Federal and State programs to encourage the use of solar energy can also provide valuable economic incentives for the use of anaerobic digestion.

All of these factors combined will very likely result in a tremendous growth in the use of anaerobic digestion on farms. It is important that reliable and efficient systems be developed now that can operate on a farm scale. The research conducted over the past two years at the anaerobic digester in Monroe has focused on examining the problems encountered in operating a full scale system and on improving the feasibility of these systems for farm use. Work has centered on increasing system'net energy, decreasing operator time, and improving system reliability. The experience at Monroe has shown digestion to be feasible and workable at farm scale. The information generated can be used to develop simple systems that can be integrated into farming operations. Operating demonstrations of reliable, economical, and commercially available systems are essential for anaerobic digestion to achieve its potential capacity to provide a significant amount of energy to the agricultural sector. 


\section{SYSTEM DESCRIPTION}

\section{A. Introduction}

A full scale anaerobic digester was built on the Washington State Dairy Farm in Monroe, Washington, in January of 1976 by Ecotope Group of Seattle (Figure 1). Funds for the digester were provided by the Washington State Department of Ecology as part of a program to upgrade the farm's manure handling system for the purpose of water pollution control. The system was run until May, 1976 and then shut down. In June of 1977 funds were granted by U.S.E.R.D.A. to restart the digester, document operation and maintenance characteristics of the system, and to prepare an operator's manual that would allow the State to resume operation of the project. The system was run continuously from August 1977 through August 1979 by Ecotope Group personnel. The operation of the digester was taken over by the prison system in September 1979 and the gas produced will be used to fuel the boiler in the farm's creamery.

Fig. 1 Schematic of Monroe Anaerobic Digestion System

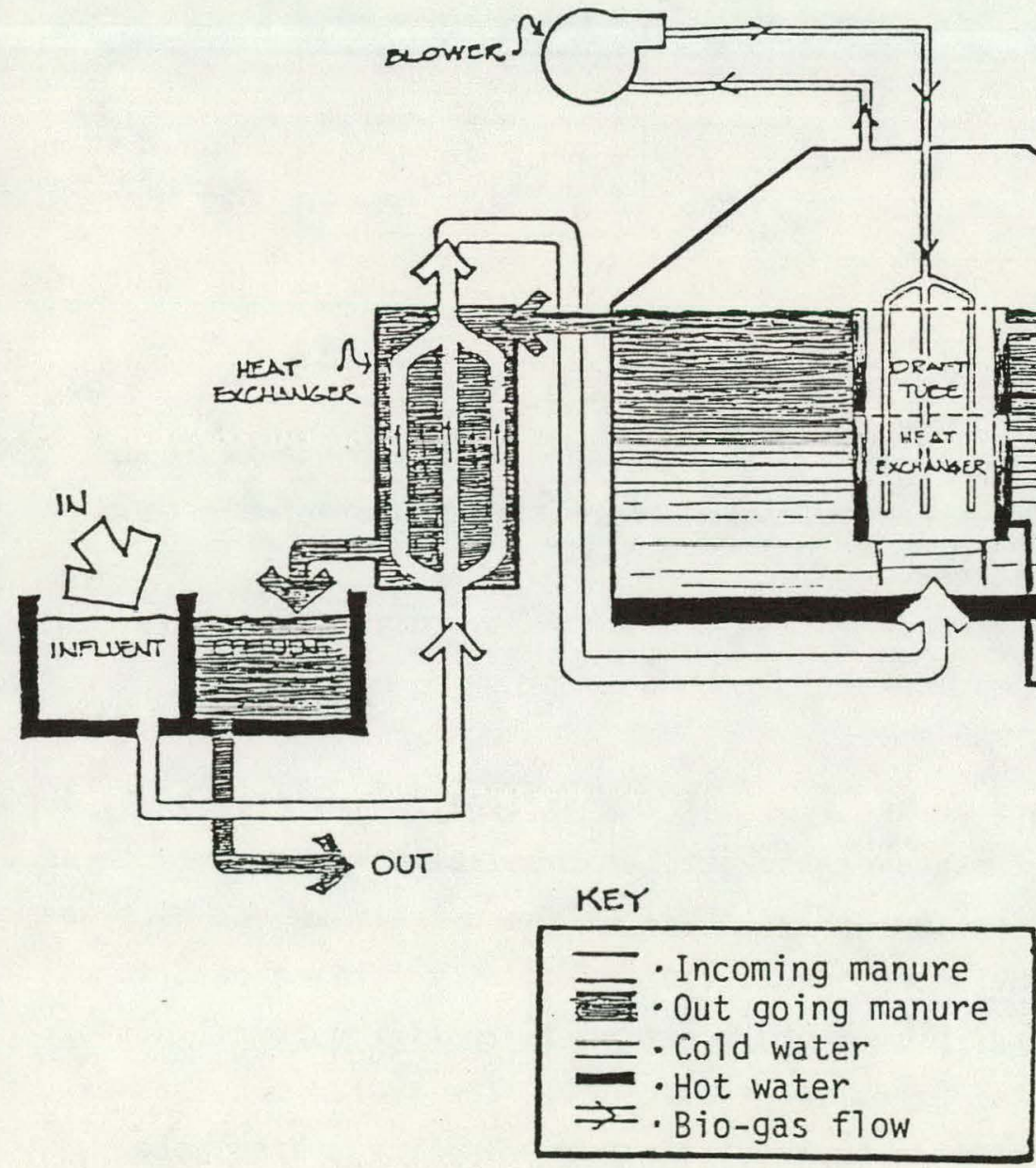


The Washington State Dairy Farm is located $56 \mathrm{~km}$ (35 miles) north of Seattle, and is operated in conjunction with the State prison system as a minimum security penal institution with 30 inmates and 10 civilian employees. The 250 -acre farm has 400 head of Holstein cattle, with a milking herd that varies from 180 to 200 cows, and a creamery to process milk, cottage cheese, and ice cream for use in government institutions (Figure 2).

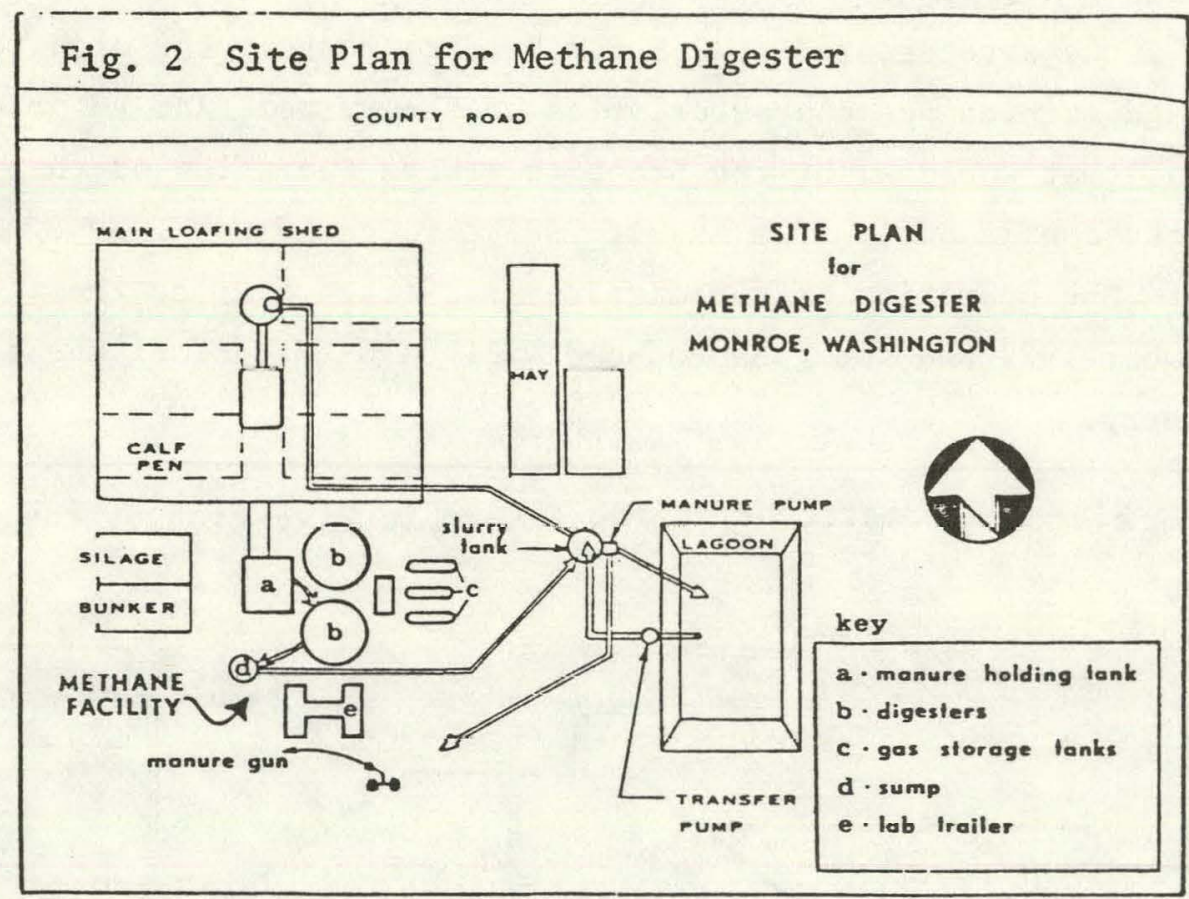

The milking animals are housed in a covered loafing shed with a concrete floor and individual sawdust-bedded stal1s. Only the manure from those animals in the loafing shed is used in the digester.

\section{B. Design}

The Monroe digester was designed on the model of a municipal sewage treatment plant digester, and was a transfer of state-of-the-art treatment plant technology to an agricultural application. During the design phase of the system, an emphasis was placed on the use of off-the-shelf components that are easily obtainable. It was felt that using equipment already proven and accepted in the agricultural sector would speed the widespread use of digestion technology. The system consists of four major subsystems: the digestion tanks, the manure handling system, the 
digester heating and mixing system, and the gas handling and utilization system. The components of each subsystem were chosen on the basis of commercial availavility, cost, proven effectiveness, and energy consumption.

\section{Tanks}

The digester tanks are an example of the integration of agricultural sector products with sewage treatment technology. The reactors are two $189 \mathrm{~m}^{3}$ A.O. Smith Slurrystore $_{t m}$ tanks fitted with Harvestore ${ }_{t m}$ silo roofs. These fixed cover tanks are 7.82 meters in diameter and 4.57 meters in height. The tanks are glass-1ined steel tanks that are built to be corrosion resistant. Certain modifications are made to the tanks for use as experimental anaerobic digesters. In addition to the Harvestore manhole covers added to the roof and sides of the tanks, two thief holes were installed on the digester roof for sampling digester contents from the tank interior. Eight side-mounted sampling ports were installed at three levels around the perimeter of the tank to provide a variety of sampling locations.

The most significant tank modification was the insulation of a11 exposed tank surfaces. The interior roof of the tank was sprayed with $8.8 \mathrm{~cm}$ of polyurethane foam $(R-12)$. Exterior walls were covered with $10 \mathrm{~cm}$ of Dow Styrofoam $\mathrm{SM}_{t m}(\mathrm{R}-22)$, and covered over with corrugated galvanized iron roofing sheets.

\section{Manure Handling System}

The digester was designed to integrate into the farm's existing manure handling practices. The concrete center aisle of the loafing shed was extended out the south side of the shed, and a concrete tank with an iron grate covering was built at the end of the aisle (Figure 3). Each morning manure is removed from the loafing shed by a tractor with a rear-mounted scraper. Since manure is scraped only once a day and includes sawdust and woodchips used for bedding, it often contains thick clods of manure and is drier than a pure, continuously scraped substrate. Water is added to the manure in the influent tank, and the contents are mixed with a $7.46 \mathrm{kw}$ centrifugal chopper pump with a $5 \mathrm{~cm}$ iron pipe by-pass on the discharge line. To provide mixing of the slurry, manure is pumped from the bottom of the influent tank and discharged through the by-pass pipe that is aimed at the surface of the manure. The pipe is moveable and can be directed to areas of the tank that require mixing. Either the chopper pump or a variable speed progressive cavity pump is used to load the slurry into the bottom of the digester. 
As manure is loaded into the bottom of the digester, the liquid level in the digester rises and manure is displaced through an overflow pipe at the top. From there it

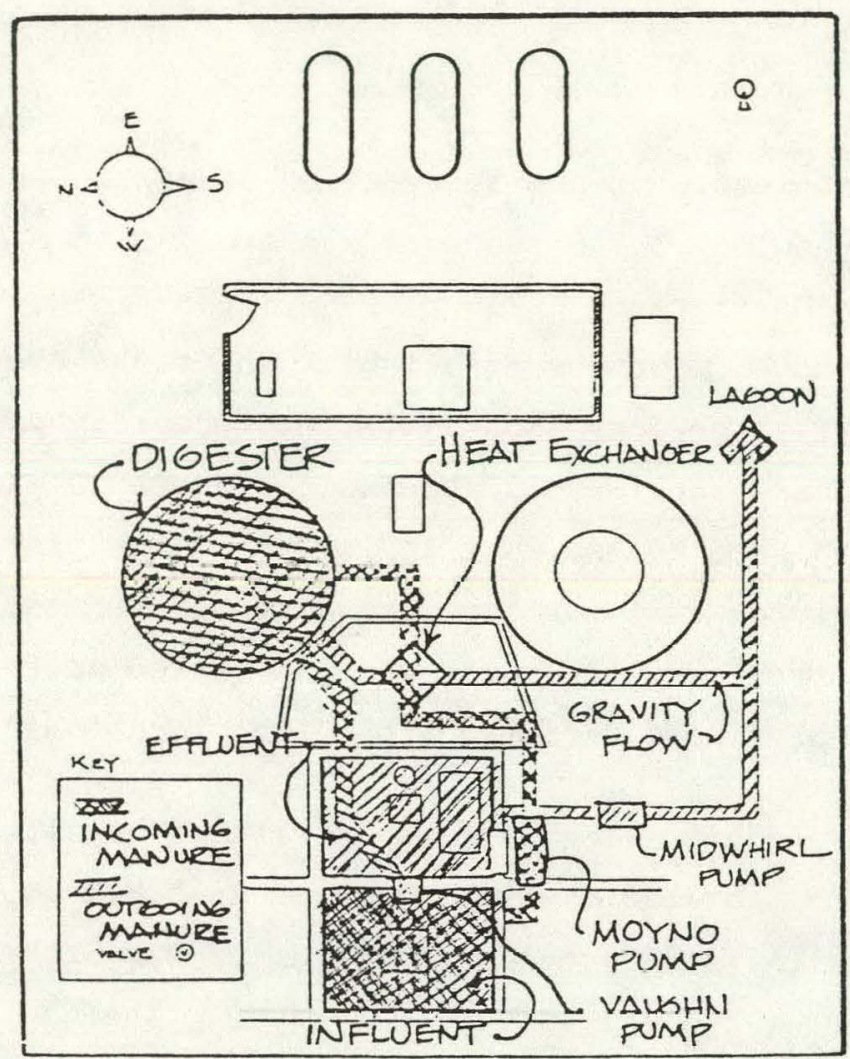

Fig. 3 Manure Handling System

flows into a storage lagoon, and is eventually applied to the field with spray guns. The manure is used to fertilize crops grown for cattle food.

\section{E. Digester Heating and Mixing Systems}

Because of the emphasis placed on the use of commercially available equipment, only two pieces of equipment were specially fabricated for the project. One was an influent/effluent heat exchanger, and the other was a draft tube heat exchanger that constitutes the core of the digester's mixing and heating system (Figure 4 ). The draft tube heat exchanger consists of two connected concentric cylinders of galvanized metal through which hot water flows. The digester operates at $35^{\circ} \mathrm{C}$. Hot water is circulated through the internal heat exchanger from either the boiler or from the coolant system of an internal combustion engine that burns biogas to produce electricity. The heat exchanger doubles as a draft tube for use in conjunction with the digester mixing system. 
Because of scum formation problems experienced in municipal sewage treatment plants, the Monroe digester was designed to be continuously mixed by gas recirculation.

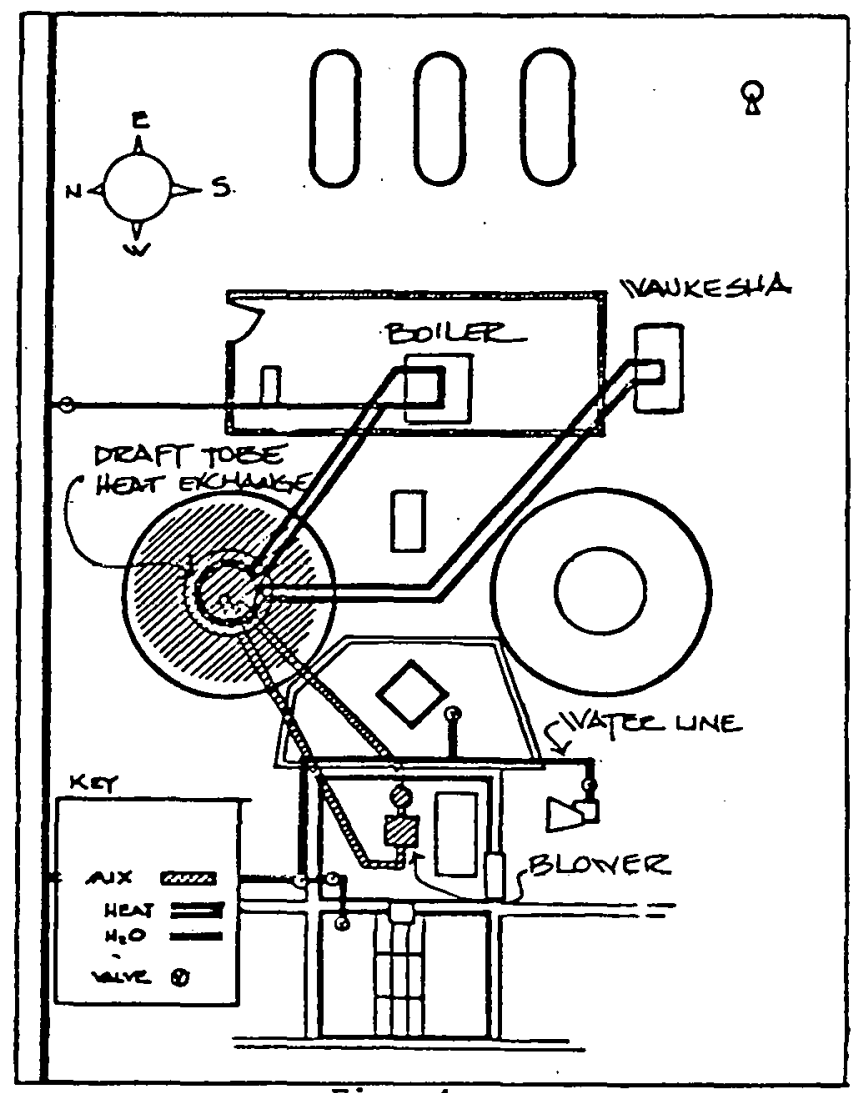

Fig. 4

Digester Mixing and Heating System

Experience with operating the digester while loading a high \%TS has demonstrated that mixing is unnecessary. In the gas recirculation mixing system as installed,

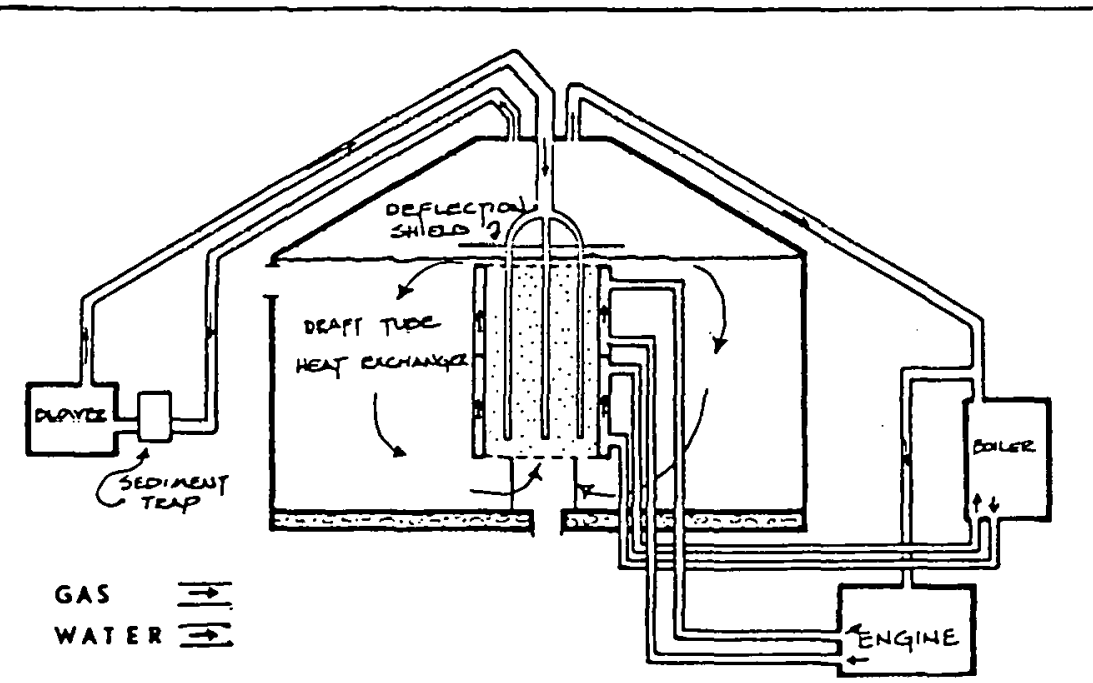

Fig. 5 Cross section of Digester Heating and Mixing System 
gas is pulled from the top of the digester and recirculated with a blower that opera+oc at $35 \mathrm{kPa}$. The gas is pumped back into the digester and down four $5 \mathrm{~cm}$ galvanized iron pipes that are supported by a deflector plate at the top of the draft tube. When gas is released, rising bubbles mix with manure and carry it to the top of the draft tube providing a circulatory action (Figure 5).

F. Gas Handling System

The gas handling components of the Monroe system were modified little from those used in standard sewage treatment gas handling. Consequently, this proved to be one of the most expensive aspects of the system (Figure 6). The gas handling system was automated using pressure switches (Figure 7). Emptying water traps at low points in the gas lines is all that is done manually.

According to the original design, gas was to be either burned directly in the boiler for heating the digester, or scrubbed and stored for later use. 'l'he'primary use for the gas was burning in order to produce process steam in the farm's creamery. It can also be used in an internal combustion engine to produce electricity in emergency situations.

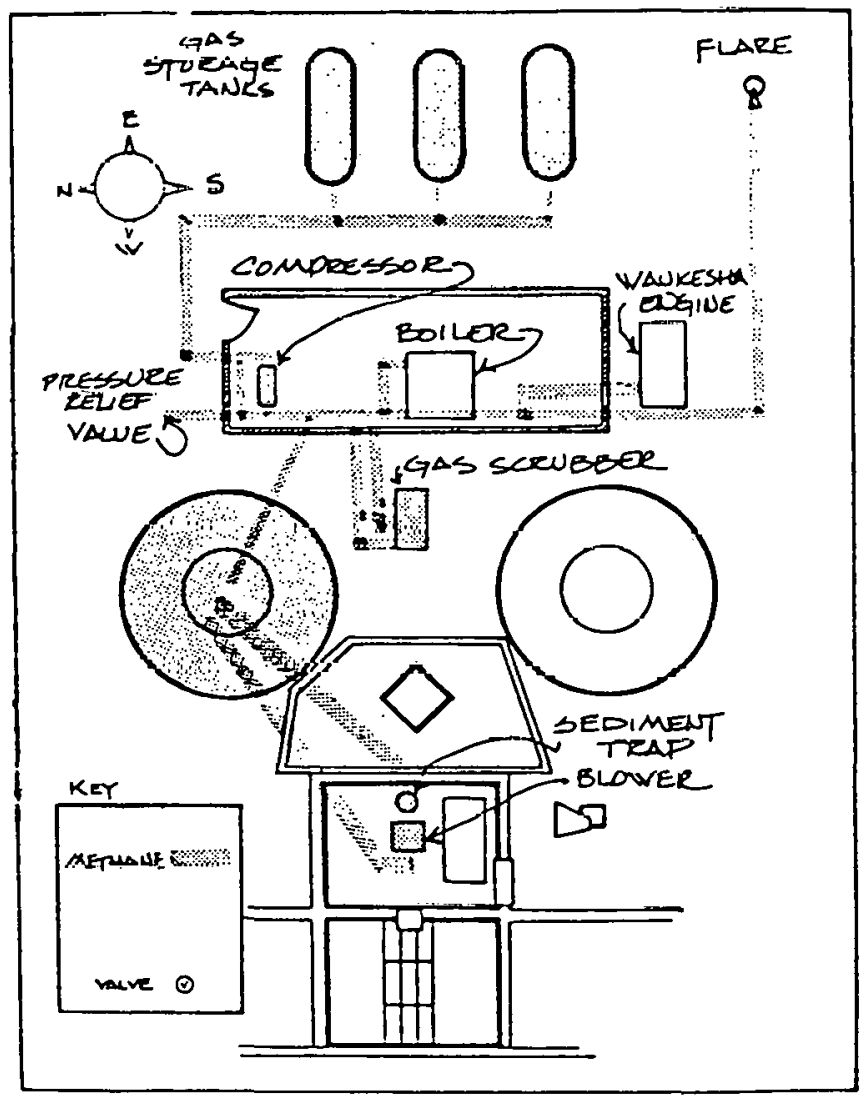

Fig. 6 Gas Handling System 
The low pressure system was designed to meet the constraints of the upper and lower pressure limits of the digester tank. The tank was pressure tested to $4.9 \mathrm{kPa}$. Pressure relief valves were set at $0.5 \mathrm{kPa}$ vacuum and at $2.7 \mathrm{kPa}$ positive pressure. As gas is produced, it will first be available to the boiler. If the digester thermostat indicates heat is needed, the boiler will turn on and burn raw biogas. Once the digester is brought up to temperature, the boiler will shut off and the gas pressure in the system will rise. When it reaches $2.4 \mathrm{kPa}$, a compressor is activated if storage tanks are below maximum pressure $1.65 \mathrm{MPa}$.

If system pressure falls below $1.7 \mathrm{kPa}$, the compressor will shut off to prevent reducing the system pressure to below satisfactory limits. When the gas storage tanks are up to pressure, the compressor will shut off and system pressure will again rise. When it reaches $2.7 \mathrm{kPa}$, a flare is activated and will run until system pressure is reduced to $2.4 \mathrm{kPa}$. If the pressure goes above $2.7 \mathrm{kPa}$, a.relief valve on top of the digester will release gas. There is also a back-up pressure relief valve set at $4.0 \mathrm{kPa}$. When both of these relief valves fail, tank contents are forced out through a $15 \mathrm{~cm}$ diameter PVC overflow pipe on the effluent line.

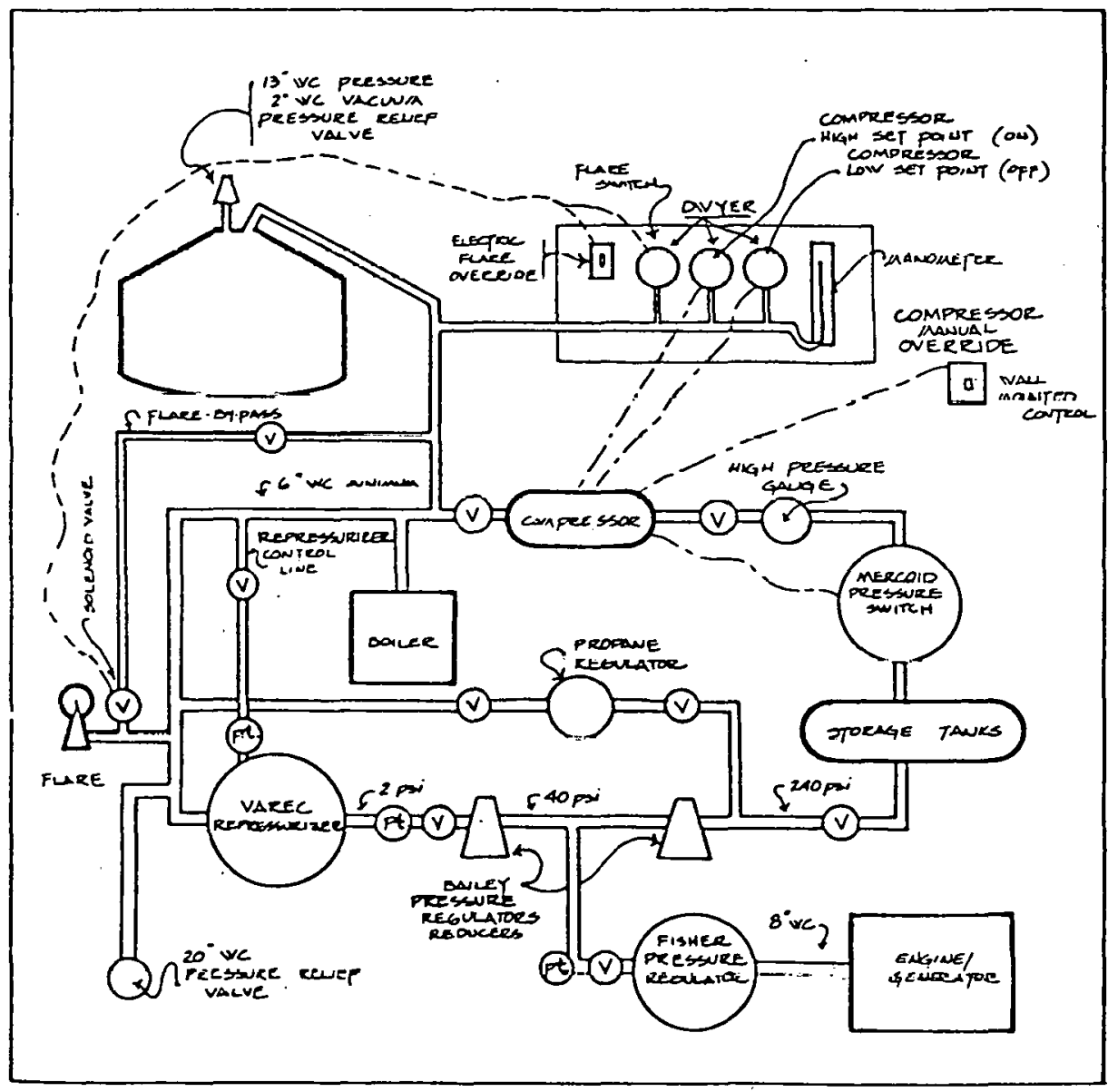

KEY

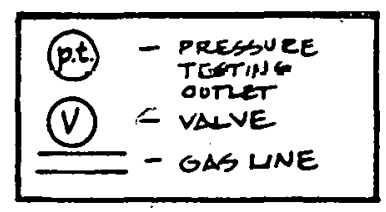

Fig. 7 Gas Handling Equipment Schematic 
Three $3.79 \mathrm{~m}^{3}$ propane tanks are used for storing biogas. These tanks have a working pressure of $1.65 \mathrm{MPa}$ and are capable of storing $62 \mathrm{~m}^{3}$ of gas each. A Corken two-stage compressor with a $1.5 \mathrm{kw}$ motor is part of the storage system. Gas that is compressed first passes through a hydrogen sulfide scrubber to extend compressor life.

An internal combustion engine with a 40 KVA..(peak) generator was installed. as a part of the original demonstration project. The purpose of this installation was to provide emergency back-up electricity for the creamery and milking operations. Because it was sized to meet peak electrical needs and not to be compatible with daily gas production rates, it required a gas storage system. The engine is a Waukesha VRG 310 natural gas engine with a dual fuel Impco Model 200 carburetor. The engine is directly coupled to a Kato generator. When the I.C. engine is operated, waste heat from the coolant system can be circulated through the upper portion of the heat exchanger.

\section{G. Monitoring Equipment}

The digester was outfitted with monitoring equipment to assess system performance and energy production. Gas meters were installed to measure gas production and consumption of the boiler, the I.C. engine, and the flare. Electric meters were installed on pumps, the mixer, and the I.C. engine. Temperature probes were installed at a variety of locations in the tank to monitor material and heat movement within the tank. A laboratory was also installed at the site to monitor the biological health of the system.

The system has been operated and maintained for two years. The biological stability and handling characteristics of dairy manure differ so significantly from municipal sewage that many of the original design assumptions were incorrect. Anaerobic digestion of dairy wastes is simpler and more reliable. Systems designed on a sewage treatment model will be oversized, inefficient and prohibitively expensive. The information gained at Monroe can be used to simplify and correctly design anaerobic digestion systems for dairy farm operations. 


\section{OPERATIONAL EXPERIENCE}

The digester at Monroe consists of four subsystems: the digestion tanks and insulation, the digester heating and mixing system, manure handling, and gas handling and utilization. Operational experience with each of these subsystems has provided information on how to reduce the capital cost of a digester by eliminating unneccessary equipment, decrease operator time and maintenance cost, and improve the net energy of the system.

\section{A. Tanks and Insulation}

In designing the digestion system at Monroe, the necessary volume was calculated by assuming a maximum loading consistency of $8 \% \mathrm{TS}$ and an optimum retention time of 20 days. Based on sewage treatment experience, it was felt that these limits were necessary for the health of the digester. The calculated digester volume needed was $441 \mathrm{~m}^{3}$, and two $4.57 \mathrm{~m} \times 7.62 \mathrm{~m}$ tanks were chosen. Once loading began, the impressive stability of the biological parameters led us to increase the loading rate, decrease retention time, and eventually to increase the \%TS of the manure loaded. As a result of these changes, we have been able to load all the manure received from two hundred cows into one digester tank. In rigid tank digester systems, the reactor tank represents a significant capital cost. Such systems should be designed to load a thick manure slurry of approximately $10 \%$ total solids with retention time of approximately 15 days in order to avoid paying for unneeded digester volume.

\section{Corrosion}

The A.O. Smith Slurrystone tanks are constructed from glass lined steel sections. One of the tanks had been in continuous operation for two years, and was recently emptied and examined for corrosion. No corrosion was evidenced on the interior walls, or on any of the plastic coated bolts used to fasten sections of the wall together. There was corrosion on one of the untreated bolts used to install sample ports. Significant corrosion was occuring on the fastening bolts on the exterior of the tank. A number of bolts on the roof were rusted. The most consistant occurrence of corroding bolts was near areas with known small gas leaks such as thief holes and the pressure relief valve. The mixture of biogas and oxygen appears to be much more corrosive than just oxygen. The limiting factor in the life of the tanks seems to be the lifetime of the nuts and bolts. During construction, nuts and bolts should be protected from corrosion by covering them with a tar-plastic compound. 


\section{Cleanout}

When designing a rigid tank system, provisions should be made for periodic removal of grit accumulation. Frequency of cleaning can be reduced by removing as much grit as possible from the manure before it is pumped into the digester. Agitation inside the tank can help keep the grit in suspension, but there is a high energy cost for such mixing. There will still be some grit accumulation, however, even with attempts to reduce it. Options that will allow grit to be removed without shutting down the digester are preferable because of the difficulty and danger associated with shutting down a digester. A sloping floor that consolidates the grit and an auger system to remove it is one possible solution for periodic cleanouts of grit.

The Monroe tank had no such provision, but was equipped with a $30 \mathrm{~cm}$ drain which allowed the digester to be emptied into the effluent tank. There is also a manhole in the side of the digester that allows access to the tank. The $30 \mathrm{~cm}$ drain allowed flushing out the solid organic material remaining in the tank after the fluid was removed. Some of the sand was also removed this way, but it repeatedly clogged the lines and was more difficult to remove from the effluent tank than from the digester.

Ultimately, the grit had to be shoveled out of the digesler through tho manhole opening. This was a very laborious and time consuming job, and is one of the least preferable options for grit removal. If a digester is designed for manual grit removal, tank openings should be located in an area that has easy access for a wheel barrow and be of sufficient size to allow for easy entry and exit of the digester.

\section{Insulation}

Three types of insulation were used on the digester : polyurethane foam, beadboard, and blue styrofoam. The polyurethane foam was applied to the interior of the tank roof to allow easy access to exterior roof bolts, in case of a gas leak. I I was the most expensive type of insulation used. Polyurethane was chosen because only a spray of insulation could be applied to the interior of the roof. After two years of contact with manure and biugas, therc was no evidence of significant degradation of the insulation.

The exterior walls of the tank were originally covered with beadboard insulation. The beadboard was then covered with tar. Although the insulation was relatively inexpensive, it was not adequate. The rainy climate of the Pacific Northwest 
resulted in the beadboard absorbing water and losing its insulation value. The beadboard was then removed and replaced with blue styrofoam. Four inches of T. \& G. blue styrofoam were applied to the tank in August of 1977. It was covered with corrugated sheet metal. This insulation was approximately $50 \%$ more expensive than the beadboard but has worked much better. No problems with water absorption have been found. 


\section{B. Manure Handling}

\section{Introduction}

Probably the most difficult aspect of operating the digester at the Monroe facility is manure handling. Traditionally, this has been one of the greatest problems facing dairy farmers. Common manure handling problems, such as pump performance and maintenance, and clogging of pipelines, are compounded in a digester system owing to the thicker manure slurries handled. Thicker slurries are desireable because they result in reduced digester heating demand. Obviously, there is a trade-off in gas heat energy, and pumping and mixing operating and maintenance costs.

Manure handing is a critical component governing the success of an anaerobic digester. The amount of work required to $\operatorname{mix}$ and load manure to a digester need not. be greater than that required for typical handling practices, in fact, it could be less. For optimum gas production, a continuous scrape system, with no foreign matter, water, or bedding added, is ideal, although this system would be most costly to install and operate. In practice at Monroe, daily scraping with some bedding, a minimum of water and, unfortunately, a great variety of foreign matter, is a more typical system. Several examples will serve to show how these principles affect digester operations.

A dirt feedlot scraped out only occasionally demonstrates two points. First, the manure will have undergone partial degradation and will not produce as much gas as fresh manure. Second, the dirt and other debris scraped with the manure, if not removed, will gradually fill in the digester, reducing its effective volume and possibly causing clogs.

A manure washdown system illustrates a third point. This manure is usually too watery for efficient digestion. Water with the manure must be heated to the digester temperature, thus consuming gas, but not lending to increased gas productlon. A more dilute digester slurry also requires a larger digester volume adding extra capital cost to the system.

Finally, bedding, such as woodchips or straw, can both clog in certain pumps and pipes and contribute to a rapid scum layer build-up if it floats. To minimize this build-up, which can retard gas production and cause effluent clogs, mechanical or hydraulic mixing can be used, but at added capital and energy expense. Another possibility is to maintain a thicker digester slurry so that material that normally floats in a thinner liquid will remain in suspension. 


\section{Pipe Clogs}

Pipe clogs have demanded an excessive amount of attention at the Monroe facility. To minimize clogs, it is best to understand the different ways that they occur, so that potential clogging conditions are eliminated by design. The most obvious clogs are those caused by a large particle or object either partially or completely blocking flow. Smaller particles will catch and build on the immovable ones, worsening an already restricted flow situation or halting flow completely. This type of clog is most common on raw manure influent lines containing foreign materials. Rocks, knots of wood, cow tags, bailing wire and aluminum cans have been found to block a $5 \mathrm{~cm}$ diameter line used for influent mixing. The problem is much more acute at the point where material enters this pipe from a $10 \mathrm{~cm}$ diameter 1 ine and at a $5 \mathrm{~cm}$ diameter elbow. In an otherwise "clean" raw manure stream, bedding, feed pellets, and dried clumps of manure have also clogged $5 \mathrm{~cm}$ diameter pipe.

Small pipe diameters and large reductions in pipe diameter on hydraulic mixing and loading lines should be avoided. Up to $\frac{1}{2}$ hour or more may be spent freeing just one clog, if manual removal and freeing of pipes is required. This sometimes involves climbing down into the influent mixing tank. Ordinarily, flushing with a stream of high pressure water. will dislodge a clogged line, although if backflushed, there is no assurance that the line will not become clogged with the same material again.

Raw manure, and less frequently, digested manure, when left remaining in pipes long enough, begin to thicken and "cake". If lines are not used daily, they may require flushing out with water to prevent this type of clog. This effect was much more evident in flexible hose and occurred even in $10 \mathrm{~cm}$ diameter sections. 'The evaporation or leaking of water from the slurry contributes to this effect, leaving a drier material behind to cake. This type of clogging is usually dispersed by an increase in gravity or pump head. A water flush can also sometimes be useful.

Heavier solids such as sand or gravel settle out of watery manure slurries. The digester has illustrated this process; after two years of operation, almost $30 \mathrm{~cm}$ of sediment was found on the digester floor. Practicaliy all pipe clogs of this nature were in the effluent lines, since digestion reduces solids levels approximately $30 \%$. The percent total solids level of raw manure loaded is normally $10 \%$ TS; that in the digester and effluent is about 7.5-8\% TS. Most settling clogs in effluent lines have been noted at solids levels below $7.5^{\circ} \mathrm{TS}$, the lower level due to boiler or fresh water leakage, or dilute slurry loading to the digester. 
Settling clogs only form in horizontal pipes and at low velocities. In an effluent section where the pipe diameter reduces to $7.5 \mathrm{~cm}$ from $10 \mathrm{~cm}$, sand deposited in and blocked only the $10 \mathrm{~cm}$ section. In the $7.5 \mathrm{~cm}$ line there was sufficient velocity to keep the sand moving in suspension. Large pipe diameters and pipe reductions on horizontal effluent lines, therefore, should be avoided. Settling clogs are best removed by high pressure water or air.

3. Pumps

Successful pump selection is a major component of the efficient manure handling system. A pump should not only be properly sized but suited to handle the nature of the substrate at hand. Along with a manure slurry, there may be bedding, gravel, or other foreign matter that must be accounted for.

Before selecting the best pump for a job, the decision should be made whether a pump is needed at all. In the case of transporting digested effluent, at the Monroe digester, this stream is now moved over 50 meters from the digester to the holding lagoon by gravity. About $4.5 \mathrm{~cm}$ of static head is available for this purpose using $10 \mathrm{~cm}$ diameter vertical PVC pipe and $7.5 \mathrm{~cm}$ diameter horizontal PVC pipe. Digested manure is a far more homogenous fluid than raw manure, and for this reason, causes far fewer clogging problems in smaller diameter pipe.

Loading raw influent to a digester by gravity is not a simple matter. Raw manure does not flow well if very thick or not well mixed. This is an area that needs further investigation. At the Monroe facility, three pumps have been tesced for loading in various ways. Of these, one pump also mixes the influent. An independent mechanical mixer has also been tested as a possible improvement.

A centrifugal chopper pump (Vaughan Co., Inc.) was intended to mix the influent by chopping and recirculation, but it is also able to load. Manure is mixed by two separate means operating simultaneously. The centrifugal impeller chops up any manure clumps that it draws in from the tank bottom. Also, a movable recycle pipe on the discharge line of the pump is aimed at the slurry surface, and a high pressure slurry stream provides overall circulation of the tank contents. Since the tank is square, large clumps may sometimes get stuck in the corners which requires manual directing by an operator with a pole. Most large clumps float, due to encapsulated air and are broken up by the surface recycle stream.

Centrifugal pumps are designed for high volume, low pressure service. Smaller sized pumps may possibly develop too little pressure for handling thick slurry. A large pump may load manure too rapidly. At Monroe, a rapid loading rate caused 
gas to be forced out through the pressure relief valve. Valving down flow is limited because reducing the diameter of the valve caused clogging. The centrifugal pump at Monroe is driven by a $7.5 \mathrm{kw}$ motor. The mixing tank is approximately 3.7 meters square and 2.4 meters deep. At these specifications, and with the existing mixing capability, $10 \%$ TS has been the practical limit for easy mixing and pumping. At $12 \%$ TS, mixing becomes labor intensive and pumping is severely limited.

A diaphragm pump (ITT Marlow) works by positive displacement, and was originally intended for loading at low volume to take advantage of an influent/effluent heat exchanger. The pump is designed to handle thick slurries at low volume and high pressure, and employs suction and discharge ball check valves to maintain an airtight volume. However, the diaphragm pump has never been able to load the substrate due to bedding and other foreign material that clog the check valves, and prevent adequate seating, causing a loss of prime.

A progressive cavity pump (Moyno Pump Div., Robbins and Myers, Inc.) was obtained to replace the diaphragm pump. It also works on the positive displacement principle, but does not use check valves. Instead, a single helix rotor revolves within a double helix stator forming cavities that progress toward the discharge end carrying the substrate with them. The pump cavities were sized to handle particles up to $2.8 \mathrm{~cm}$, and a variable speed drive with an $11.3 \mathrm{kw}$ motor was selected for delivery of from $2-5 \mathrm{~m}^{3} /$ hour at up to $700 \mathrm{kPa}$. High pressure capability was desirable to insure loading thick slurries through an influent/effluent heat exchanger of unknown pressure loss. Variable speed was desirable to optimize heat exchanger performance.

The ane significant operational problem related to this pump was finding an effective means of removing large foreign objects from entering the pump. A clog at the volume reduction from suction housing to cavity may cause the pump to run dry, which leads to burnout of the stator if not quickly detected. A most crude filter on the suction pipe (5 cin square openings on a $15 \mathrm{~cm}$ diameter $1 \mathrm{ine}$ ), and an automatic shutoff switch sensing low flow conditions, were installed to safeguard the pump. The in-line filter invariably clogs due to thick slurry or foreign matter, and requires cleaning. The shut off switch has several times proved unreliable. This pump was able to load a thick slurry, but the performance of this pump exceeded mixing limitations. Up to $13 \%$ TS were pumped, but at this solids level, mixing was practically impossible with the existing chopper punp and recycle stream. This pump has not been run since the removal of the influent/effluent 
heat exchanger and return to $10 \%$ TS loading, which the centrifugal pump handles at a much faster rate.

A mechanical mixer was designed to stir the contents of the influent tank that incorporated mixing blade, shaft, support structure, and $5.6 \mathrm{kw}$ motor. This device has definite potential if properly sized. There are no clogging problems to speak of. The unit that was tested appears slightly undersized for thick slurries of over $10 \%$ TS. Mixing of the raw influent would also be easier in a circular, rather than square, mixing tank.

There are trade-offs between the energy gains that resull from increasing the percent solids loaded, and the electrical and labor demands of an influent handling system. The characteristics of manure slurry differ so significantly as the percent solids are raised, that an influent handling system should be designed for the specific requirements of that solids level that provides the most cost effective and energy efficient system possible.

\section{Pressure loss in pipes}

It has been concluded that larger pipe diameters on influent lines, rather than on effluent lines, is advantageous to minimize the kinds of clogs particular to each stream. To be able to size pipes accurately requires further knowledge of approximate pressure loss $(\Delta \mathrm{P})$. Since not much data has been reported on $\Delta \mathrm{P}^{\prime} \mathrm{s}$ for the transportation of thick manure slurries, it was decided to document typical $\Delta P^{\prime}$ 's at the Monroe facllity. Fresuuros were measured with a manometer connected to the $10 \mathrm{~cm}$ line with large $2.5 \mathrm{~cm}$ taps. (Fig. 8) Flow rates were determined by measuring and timing the drop in slurry level in the mixing tank. A sample of the slurry was collected and analyzed for : $:$ TS.

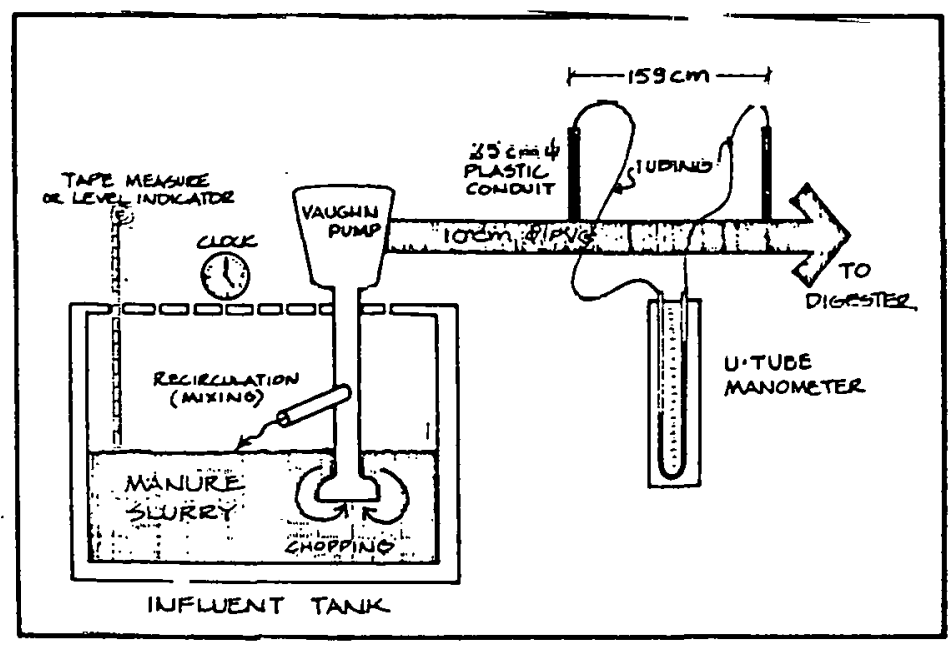

Figure 8 Diagram of Test Apparatus

NOTES: 1) $2.5 \mathrm{~cm}$ dlameles conduit is used to prevent clogging of the manometer tubing (which occurred repeatedly ith 1 . jben olampral iunduit or no rnndilit at al1).

2) Care anst be taken to mix the slurry well to insure a constant level of STS during test rums.

3) Improvements: It is suggested that a longer straight section of pipe be used in furure tests and test times be standardized. 
The results of the tests, conducted during June 1979, were $\Delta \mathrm{P}^{\prime} \mathrm{s}$ ranging from 0.048 to $0.176 \mathrm{kPa} / \mathrm{m}$ over velocities between 0.085 and $0.76 \mathrm{~m} / \mathrm{s}$ and $\mathrm{TS}$ between 9.2 and $12.5 \%$. The $\Delta \mathrm{P}^{\prime}$ 's determined are comparable to those calculated using formulas devised by Hashimoto and Chen (published by ASAE, 1976), from 0.055 to $0.143 \mathrm{kPa} / \mathrm{m}$ for TS between 8.6 and $11.4 \%$. The results indicate there is no correlation between $\Delta \mathrm{P}$ and velocity over the range tested. There is a gradual but significant increase in $\triangle \mathrm{P}$ with $\% \mathrm{TS}$. This relationship is shown in figure 9.

When designing manure handling systems for slurries of $12 \% \mathrm{TS}$, for example, $\Delta \mathrm{P}^{\prime} \mathrm{s}$ may increase $1 \frac{1}{2}-3$ times over $10 \%$ TS or 3-6 times over $8 \%$ TS. This effect is more pronounced with long pumping distances and increased numbers of bends and valves. With thicker slurries, shorter pipes and fewer fittings should be used to limit the size of pump necessary.

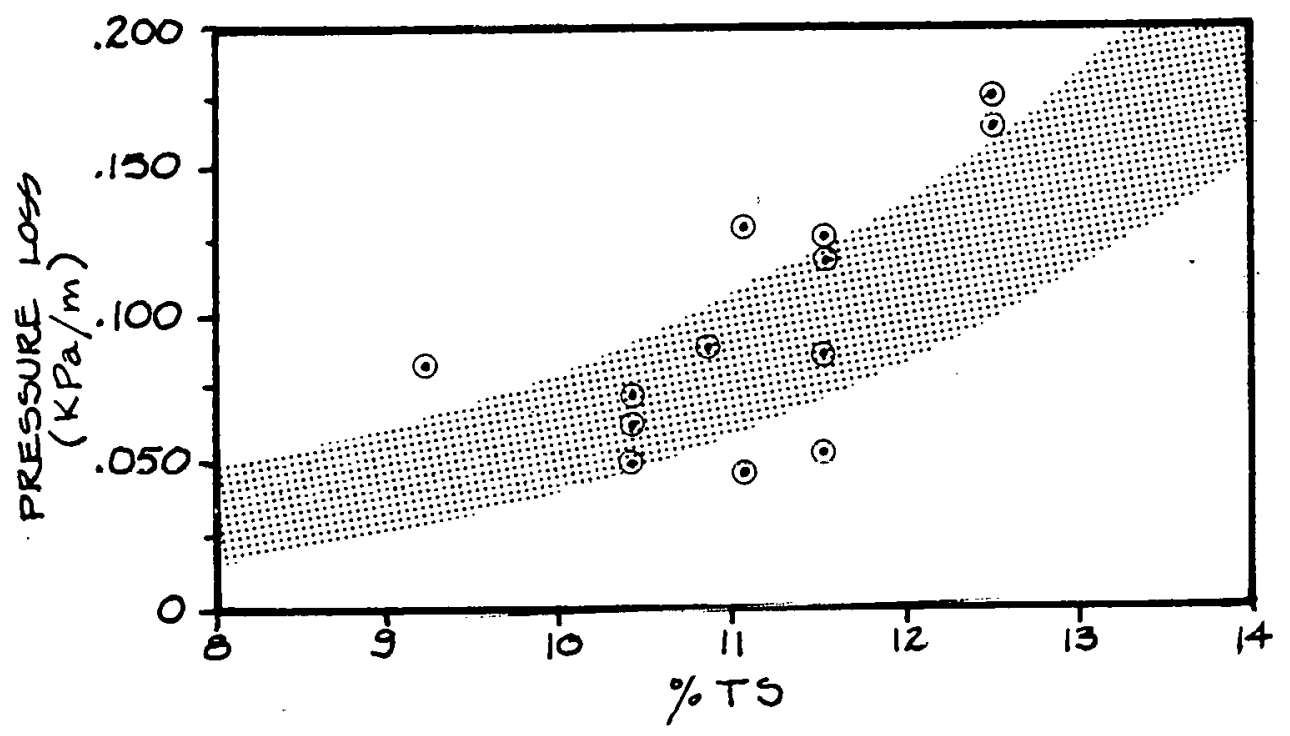

Figure 9 - Relationship between pressure loss and $g$ is 
C. Digester Heating and Mixing

1. Heating

The contents of the digester must be maintained at about $35^{\circ} \mathrm{C}$ to produce gas at the optimum rate. This requires a daily heat input to counter digester heat losses from two sources: 1) conduction skin losses and, 2) displacement of warm digested manure by cold influent. A significant portion of the daily gross gas production is needed to maintain digester temperature. Heat transfer in the tank is accomplished by the draft tube heat exchanger.

Heat loss through the skin is determined by the lieat transfur cocfficient of the digester surface, the surface area available for heat transfer, and the temperature difference between the digester contents and the outside air. All exposed surfaces of the Monroe digester were insulated. Ten centimeters of Dow Styrofoam $\mathrm{SM}_{\mathrm{tm}}$ were installed on the exterior walls, and about $8 \mathrm{~cm}$ of polyurethane foam was sprayed on the inside of the roof. The observed heat loss rate from the insulated tank was about $348 \mathrm{~kJ} / \mathrm{hr}^{\circ} \mathrm{C}$ at an ambient temperature of $0.7^{\circ} \mathrm{C}$.

Influent heating is by far the dominant factor in digester heat demand and accounts for $75-90 \%$ of the total heat demand depending on the season. The amount of heat necessary to raise the influent to $35^{\circ} \mathrm{C}$ depends on the volume loaded, the percent solids (\%TS), and the influent temperature. The influent heat demand can be significantily reduced by increasing the percest solids of the slurry lnaded. This reduces the amount of water added to the manure that must be heated to $35^{\circ} \mathrm{C}$ in the digester. Over the two years of plant operation, the percent solids of the influent has been increased from $4 \%$ to $10 \%$. The reduction in the amount of water also improves gas production because it effectively increases the retention time of the organic material in the tank.

\section{Boiler}

The heating system boiler is a National 209 Series boiler with a rated output of $396 \mathrm{MJ} / \mathrm{hr}$ : Unscrubbed biogas is burned directly to produce $49^{\circ} \mathrm{C}$ water that is pumped into the bottom section of the draft tube heat exchanger. Operation of the boiler is controlled by thermostats. A schematic of the boiler heating system is given in figure 10.

The efficiency of heat delivery from the boiler determines the gas consumption of the system. Calculations indicate that our boiler heat delivery efficiency is in the 
50-60\% range. During freezing temperatures in the second winter of operation, the boiler consumed $25.7 \mathrm{~m}^{3} /$ day of gas just to stay up to temperature. This was not a time of normal boiler operation because no hot water was circulated to the digester during this time. The magnitude of this number, roughly $10 \%$ of our normal daily gross gas production, however, suggests reducing boiler heat losses would noticeably improve the efficiency of the system.

An alternative to using a boiler is installation of a large commercial hot water heater. Although a hot water heater would be no more inherently efficient than a boiler, it would probably cost about half as much. In either case, insulation of the equipment and a thermostatically controlled stack damper valve deserve consideration in attempting to maximize heat delivery efficiency.

The original temperature measuring and controlling devices for the heat delivery system were all of mechanical design with capillary tubes from the sensor to the switch. One probe was connected to a microswitch that controlled the digester temperature by turning the boiler water pump on and off. The other was connected to a meter calibrated in $1.1^{\circ} \mathrm{C}$ increments. The sensors were mounted in two separate wells in the side of the digester.

The temperature control had a $1.1^{\circ} \mathrm{C}$ bandwidth for turning the pump on and off. The gas consumption of the boiler was very erratic on a day-to-day basis, and the hot water pump often stayed on for many hours longer than necessary. The reading of the temperature indicator also varied several degrees on sunny days. From this information it was decided that a more sensitive and accurate temperature control would be needed. A combination temperature control and measuring unit was designed and installed. Its on/off bandwidth could be varied from 0.1 to $1.5^{\circ} \mathrm{C}$; it was set to $0.1^{\circ} \mathrm{C}$. This stabilized the temperature of the digester and resulted in the ability to predict gas consumption on a daily basis given loading volume and temperature.

3. Internal combustion engine

The internal combustinn engine providcs an alteriale method of supplying heat to the digester. Engine cooling water can be circulated through the top section of the draft tube heat exchanger to use waste heat from the engine. A schematic of the system is given in Figure 11. Engine coolant provides enough heat to maintain digester temperature even under severe weather conditions as was confirmed during an operational period in December 1977 and January 1978. The engine was operated about 7.5 hours per day. Heating with engine coolant improves 


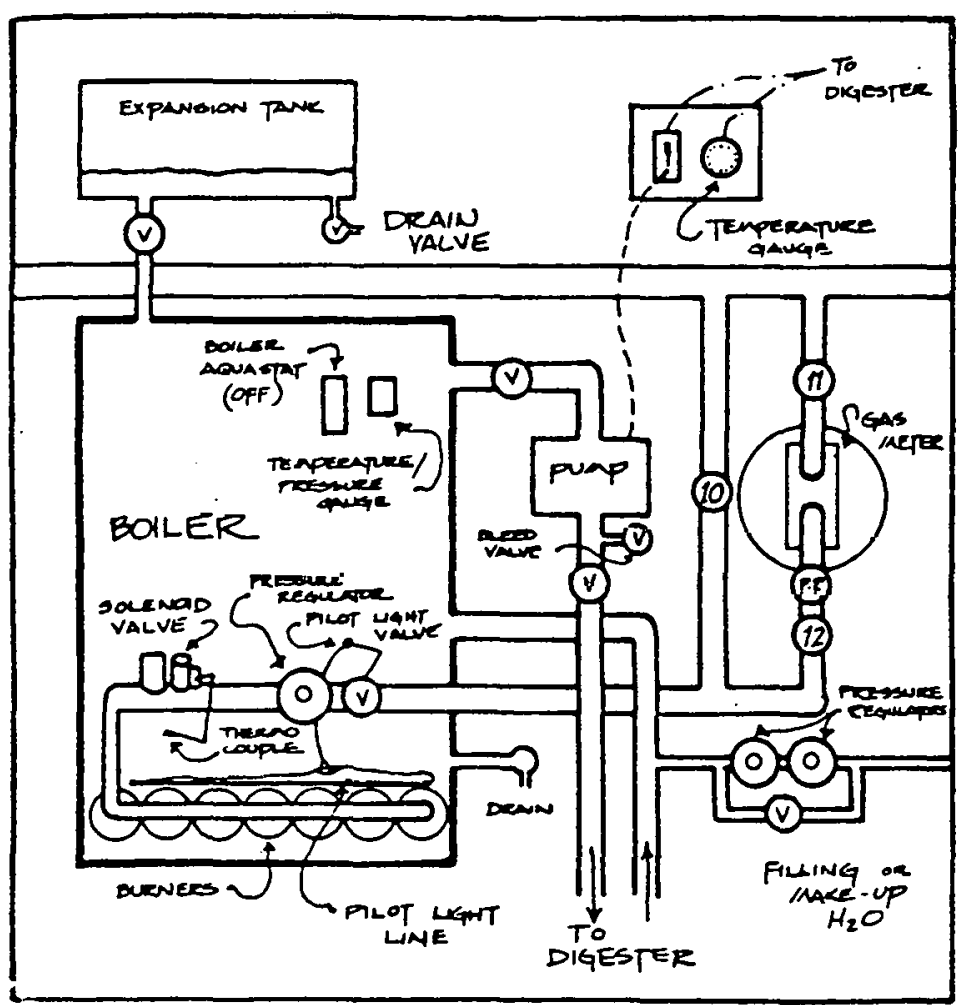

Figure 10 - Bojler Heating System

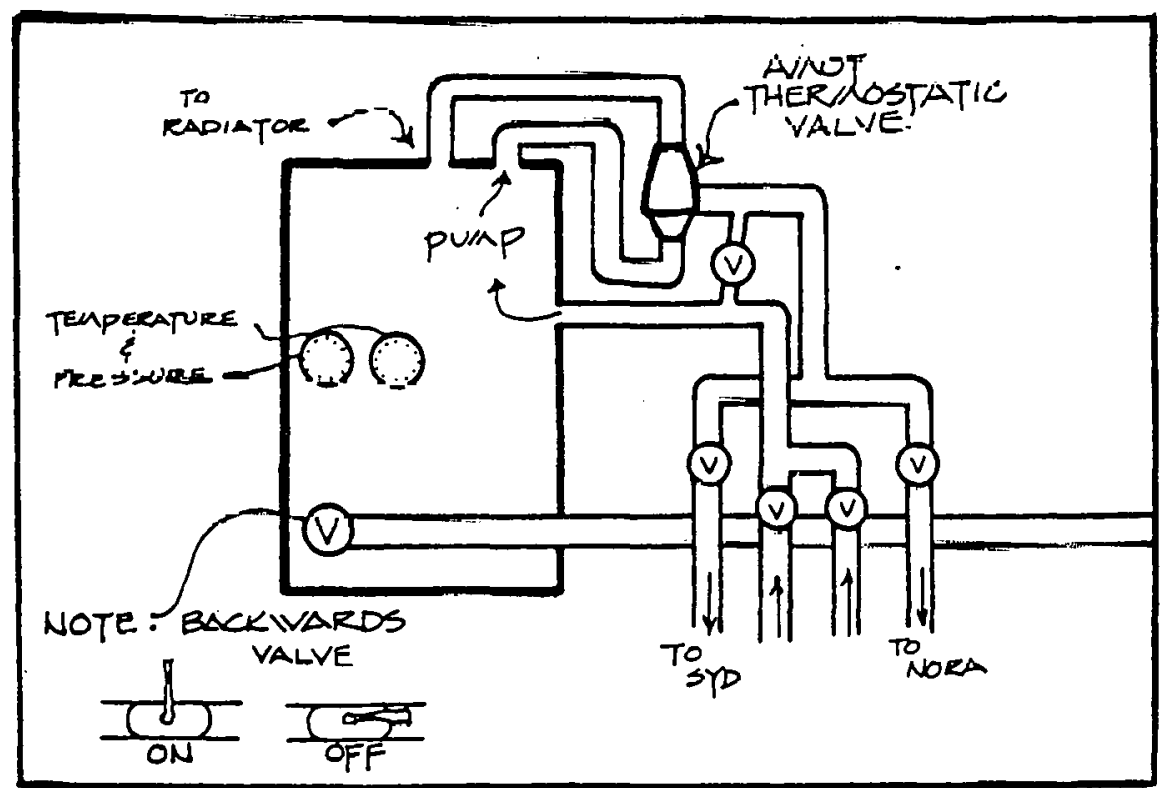

Figure 11 - Waukesha Coolant used for Digester Heating 
efficiency for electricity generation, since it replaces the need for boiler heating. Efficiency would not be as good if the engine were run for 24 hours because not all the waste heat would be needed for digester heating.

The problem with heating a digester with engine coolant is the prospect of overheating the contents with adverse effects on the microbial population. If this method of heating is used, a reliable thermostatic control of the flow of cooling water to the digester is essential.

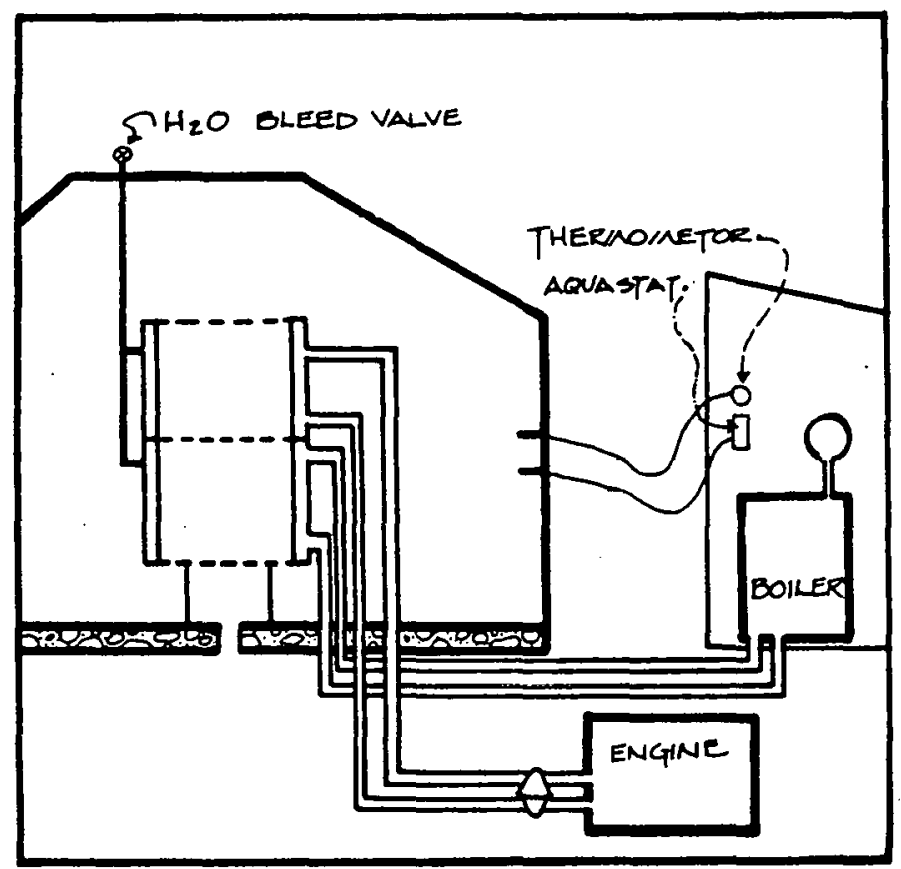

Figure 12 - Digester Heating System

4. Draft tube heat exchanger

The central component of the digester heating system is the draft tube heat exchanger. The heat exchanger consists of a concentric arrangement of an $86 \mathrm{~cm}$ OD 12-gauge galvanized pipe and $76 \mathrm{~cm}$ OD 12 -gauge galvanized pipe with end plates sealing the ends providing an annular region for the flow of hot water. The draft tube is oriented vertically in the center of the digester and divided into equal top and bottom sections that are sealed from each other by a divider in the annulus. The bottom section of the heat exchanger circulates hot water from the boiler; the top section of the heat exchanger circulates coolant water from the internal combustion engine (Figure 12). 
An overall heat transfer coefficient was calculated for the heat exchanger using appropriate empirical data and the equation,

$$
\begin{aligned}
\mathrm{U}=\mathrm{Q} / \mathrm{A} \Delta \mathrm{T} \quad \text { where: } \mathrm{U} & =\text { heat transfer coefficient }\left(\mathrm{J} / \mathrm{hr}-\mathrm{m}^{2}-{ }^{\circ} \mathrm{C}\right) \\
\mathrm{A} & =\text { heat transfer area }\left(\mathrm{m}^{2}\right) \\
\Delta \mathrm{T} & =\text { overall temperature }\left({ }^{\circ} \mathrm{C}\right) \text { driving force } \\
\mathrm{Q} & =\text { rate of heat transfer }(\mathrm{J} / \mathrm{hr})
\end{aligned}
$$

The value of the coefficient as determined was:

$$
\mathrm{U}=2.33 \mathrm{MJ} / \mathrm{hr}-\mathrm{m}^{2}-\mathrm{C}
$$

It is of interest to determine the film coefficient on the slurry side of the heat exchanger. To accomplish this, the water side coefficient was first estimated using a well known Nusse 1t-type equation. The equation for the overall heat transfer coefficient could then be solved for the slurry side film coefficient yeilding a value of $3.78 \mathrm{MJ} / \mathrm{hr}-\mathrm{m}^{2}-{ }^{\circ} \mathrm{C}$. A comparison of the water side and slurry side film coefficient shows that about $2 / 3$ of the resistance to heat transfer is on the slurry side (See appendix \#1).

The galvanized draft tube heat exchanger corroded in areas in contact with hot water trom the boller or l.L. englne. I'he zinc coating was black, brittle, and flaking in the worst areas. Areas not contacted by the hot water, such as supports were not affected. It is clear that corrosion of galvanized metals immersed in digesting manure is accelerated at temperatures above $35^{\circ} \mathrm{C}$.

Figure 13 Influent/Effluent Counterflow Heat Exchanger

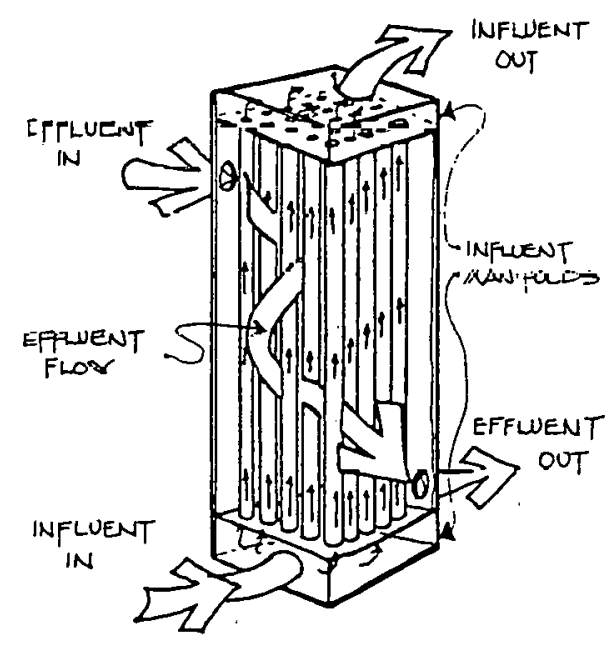




\section{Influent/effluent heat exchange}

Influent heating represents $75-90 \%$ of the insulated digester's heat demand. To recover heat from the effluent stream and use it to preheat the infiuent, an influent/effluent vertical shell and tube counterflow heat exchanger was designed and installed at Monroe (Fig. 13). The original design consisted of 25 segmented $7.5 \mathrm{~cm}$ diameter aluminum tubes joined by rubber connectors inside a metal she11.

The unit was operated in February 1976, using a $3 \%$ TS slurry, but severe clogging of the tubes occurred. Failure of a number of the tube connectors resulted in short circuiting between influent and effluent. The segmented aluminum tubes were replaced by single length thin wall PVC pipe in 0ct. 1977. This reduced the expected overall heat transfer from 58 to $50 \%$ (with $35^{\circ} \mathrm{C}$ effluent and $10^{\circ} \mathrm{C}$ influent) at $1.0 \mathrm{~m}^{3} / \mathrm{hr}$ flow rates, but eliminated the connectors. At $8 \%$ TS, the diaphragm loading pump continuously lost prime due to improper check valve seating, and was not able to move slurry through the heat exchanger. The centrifugal chopper pump was sometimes able to do so but with inconsistent flow rates, therefore heat exchanger performance testing under these conditions was unsatisfactory.

Beginning in March 1979, a progressive cavity pump was available that could dependably load high solids through the heat exchanger at low flow rates. Experiments indicated that practically no heat was exchanged in the heat exchanger. Flow was varied between 4 and $6 \mathrm{~m}^{3} / \mathrm{hr}$. Influent TS ranged from $10 \frac{1}{2}-13 \%$, and effluent from $7 \frac{1}{2}-8 \frac{1}{2} \%$. Two basic problems were isolated that account for the failure of the heat exchanger.

The first problem was stratified flow. Even after several hours of effluent flow in the shel1, about $50 \%$ of the heat exchanger shell surface area remained cold. Assuming that thermal stratification is a sign of flow stratification, it is obvious that only a limited surface area was available for heat exchange.

Due to the rheological characteristics of manure slurries, friction is greater at lower flow rates than higher. This suggests how velocity distribution within the exchanger may have been affected by pressure loss gradients and geometric asymmetry. The result is that slurry will flow along a small path of least resistance rather than moving uniformly past the entire cross-sectional area. 
A second problem is the almost complete lack of convective mixing. Because of minimal convective heat transfer, only influent slurry in contact with tube surfaces became warmed. Improved agitation to increase the amount of heat exchanged could be provided by passive means such as baffles along the heat exchanger surfaces. This was verified by tests conducted with small heat exchanger sections constructed for bench-scale experiments. When convective mixing was enhanced by baffles placed in the flow region, heat transer was improved. Stratified flow was not a problem in the test set-up due to the small cross-sectional area of the flow regions.

Influent/effluent heat exchange in a heat exchanger is hampered by the flow characteristics of the material. Since effluent is more homogeneous and freeflowing than influent and virtually devoid of foreign debris, the best prospect for heat recovery appears to be running effluent against water in a single path counter-flow design. 


\section{Digester mixing}

Based on municipal sewage treatment problems with scum formation, the Monroe digester was designed to be continuously mixed. A Rootes-type recirculation blower was used in conjunction with an internal draft tube that doubled as the system's heat exchanger. During the first five months of operation in 1977, the blower ran continuously. The electrical demand of the blower was $180 \mathrm{kWh}$ per day, representing $90 \%$ of the total electric demand of the system. The blower also required costly repairs during the time of its operation, as well as routine oil changes each week.

Table 1. \%TS of Digester Contents in Mixing Studies, 1978.

\begin{tabular}{|c|c|c|c|c|c|c|c|}
\hline sample date: & $\begin{array}{l}\text { Constant } \\
\text { Jan } 21\end{array}$ & $\begin{array}{c}\text { Mixing } \\
\text { Feb } 18 \\
\end{array}$ & $\begin{array}{ll}50 \% & M \\
M a r & 4 \\
\end{array}$ & Apr 4 & $\begin{array}{ll}33 \% & \text { Mixing } \\
\text { Apr } 29\end{array}$ & $\begin{array}{l}17 \% \text { Mixing } \\
\text { June } 1\end{array}$ & July 10 \\
\hline \multicolumn{8}{|l|}{ PER IMETER } \\
\hline \multirow[t]{2}{*}{ top } & 7.4 & 8.2 & 8.2 & 8.0 & 8.1 & 7.3 & 7.9 \\
\hline & 7.5 & 8.4 & 8.2 & 8.0 & 8.2 & 7.6 & 7.8 \\
\hline \multirow[t]{3}{*}{ middle } & 7.2 & 8.4 & 7.8 & 7.9 & 7.9 & 7.5 & 7.9 \\
\hline & 7.2 & 8.3 & 8.2 & 8.1 & 8.1 & 7.3 & 8.1 \\
\hline & 7.1 & 8.3 & --- & 7.9 & 8.2 & 7.3 & 8.2 \\
\hline \multirow[t]{2}{*}{ bottom } & 7.4 & 8.3 & 8.2 & 8.2 & 8.7 & 7.5 & 7.9 \\
\hline & 7.5 & 8.3 & 8.5 & 7.9 & 8.0 & 7.5 & 7.9 \\
\hline
\end{tabular}

Intermittent mixing was investigated in order to reduce electrical consumption and equipment wear. Baseline mixing studies were performed to determine if solids stratification occurred in the tanks. No samples differed more than $0.7 \%$ TS (Table 1). Mixing was decreased to 15 minutes on and 15 minutes off. No increase in solids separation resulted. Mixing was decreased to 10 minutes on and 20 minutes off, then to 10 minutes on and 50 minutes off, with no significant stratification and no negative impact on gas production. Stratification tests and operational experience have shown that solids separation is dependent primarily on the $\%$ TS of the slurry. If the $\%$ TS in the tank dropped below 7.5 $\%$ TS, scum formation became a problem in the effluent holding tank. 
Temperature probes were then installed in a variety of locations throughout the tank to provide a more instantaneous monitor of the movement of manure in the tank. Blower use was again reduced to loading periods only. Under these conditions, a uniform temperature drop was seen throughout the tank, indicating that the blower effectively disperses the influent during loading. Use of the blower only during loading was continued from May 1978 through early March 1979, with no negative impact on gas production or operational problems.

Mixing was discontinued on March 6, 1979. Temperature probes in the digester showed that mixing still occured in the tank without mechanical agitation due to convection currents and gas movement. A number of heating and loading configurations were investigated to examine the illpacl uf these changes on digcstcr mixing. Cold manure can be loaded to either the top or the bottom of the digester. Heating can be provided from the boiler, the internal combustion engine, or both. Hot water from the boiler circulates through the bottom of the heat exchanger; hot engine cooling water circulates through the top. If both the boiler and I.C. engine are used, heat exchange area is doubled and the hot water flow rate is substantially increased.

The natural mixing that occurs is due to gas movement and thermal convection currents from the heating system. Figure 14 shows movement from convection currents established when the boiler is running. At 2 a.m., the temperature throughout the digester was uniform. It had stabilized after the previous day's loading, and the boiler had remained off for most of the night. When the boiler turned on, agitation could be seen at the three probe points. The spikes on the chart represent manure that heated above the temperature of the rest of the tank moving past the stationary probes. The decrease in the number of the spikes from the middle to the upper probe indicates that the manure is losing heat as it rises. The small temperature difference noted by the lower probe may indicate that the manure passing it is replacing the manure that has been warmed by the internal heat exchanger. This movement continued while the boiler was on and decreased after the boiler shut off. Because we have not yet been able to perfect a flow probe that can be inserted into our sampling ports, we are unable to detect any mixing that occurs isothermally.

The impact of natural mixing with the boiler on during loading can be seen in Fig. 15. The temperature of the digester contents was relatively uniform before cold manure was loaded on the bottom. The drop in temperature at the bottom probe shows the buildup of cold manure. Sharp spikes of low temperature at the 


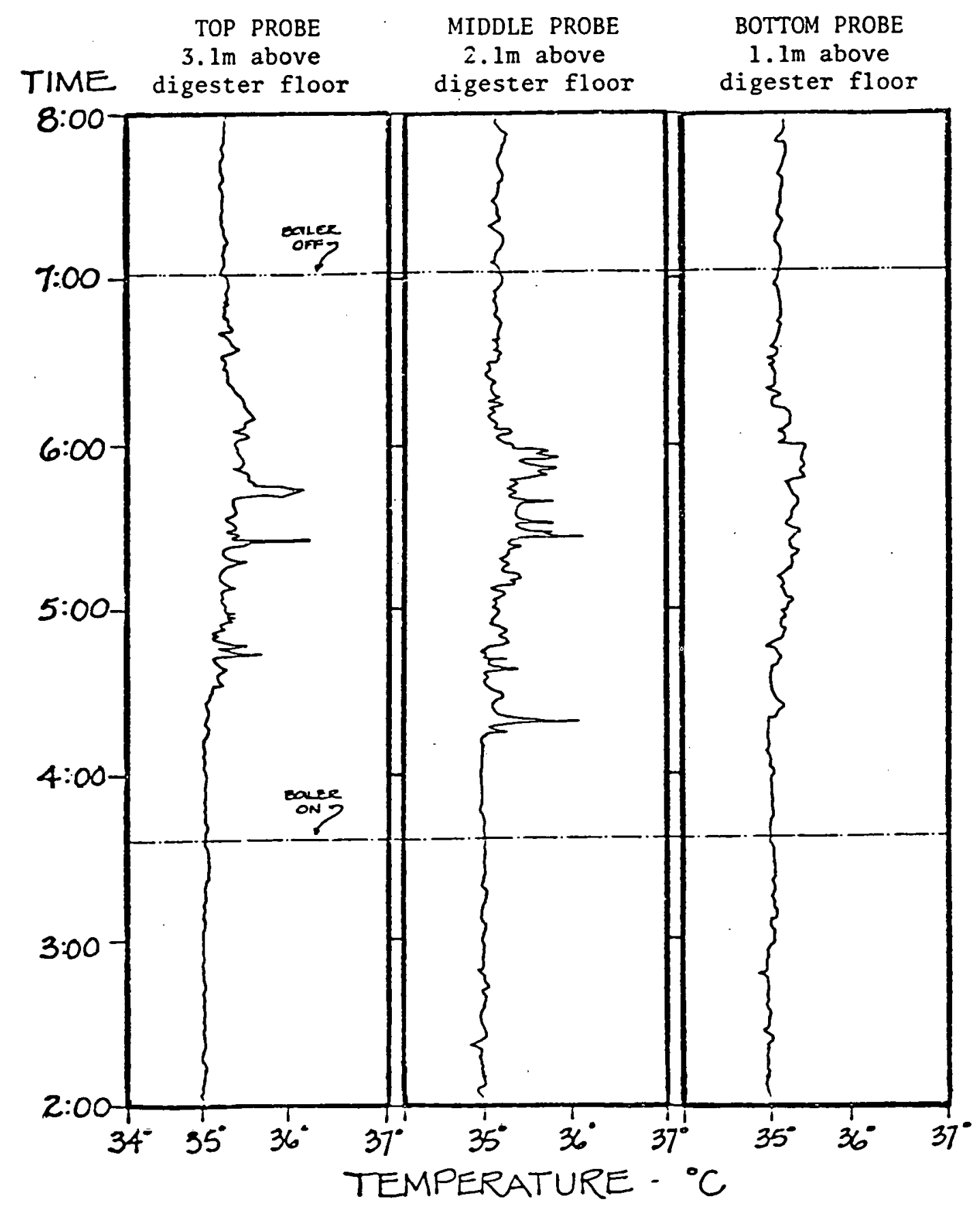

Figure 14

Temperature Probe Readings 


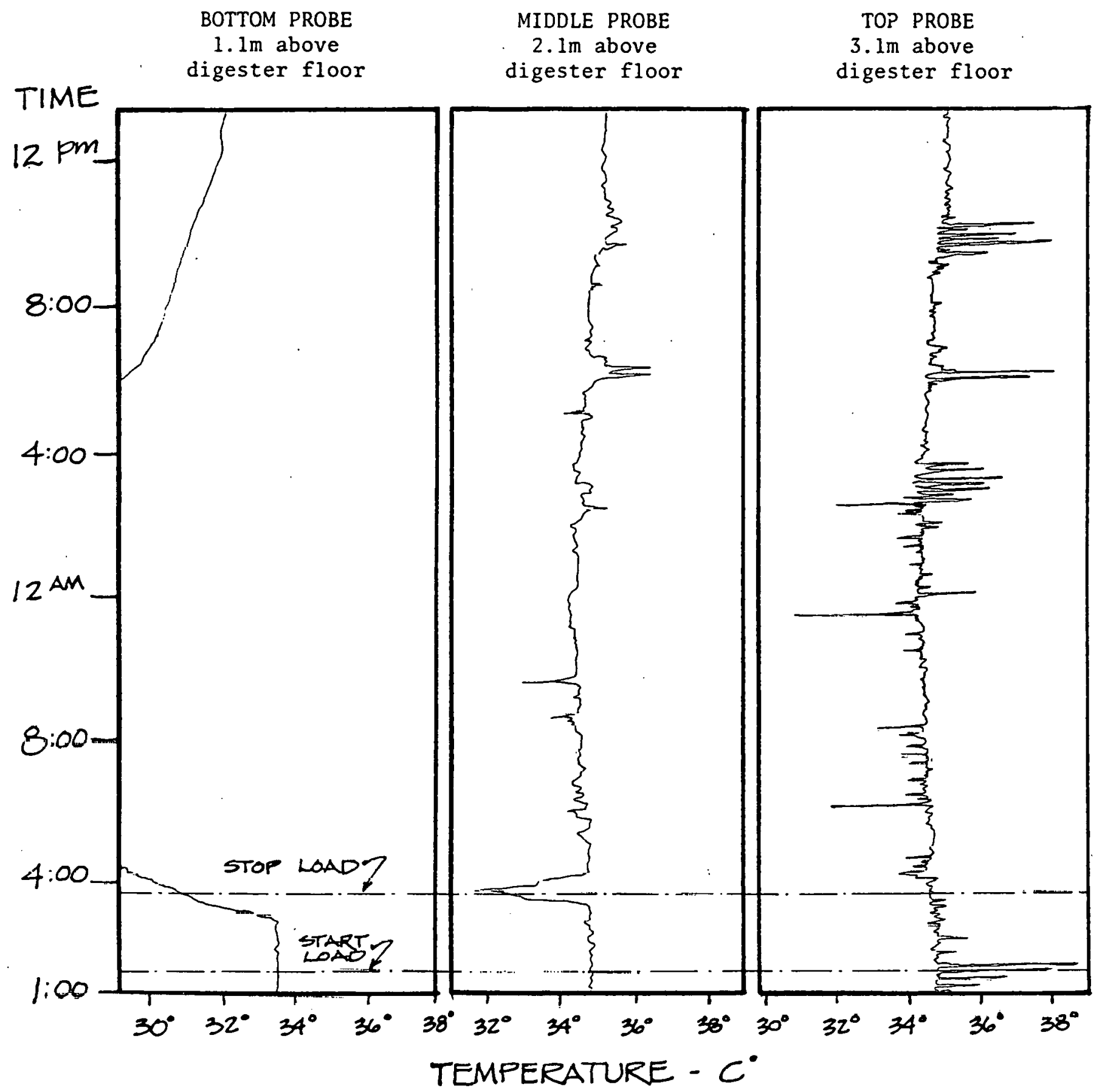

Figure 15

Temperature Probe Readings 
upper probes indicate cold manure was passing by. These probes are located at $2.1 \mathrm{~m}$ and $3.1 \mathrm{~m}$ above the bottom of the tank. Mixing could be seen for about 10 hours after loading. Warm spikes predominate after the cold manure was heated and intermixed.

Figure 16 shows the impact of doubling the heat exchanger area. In this case, heat was provided from both the boiler and the I.C. engine. The effect of this heating configuration is an increase in the speed of mixing. Even though the size of the load is slightly larger than the previous example, the accumulation at the bottom probe is less and the raw manure is mixed in rapidly. Hot spikes predominate throughout, indicating that raw manure was warmed as it was mixed.

Mixing of freshly loaded manure, when the effects of convection currents and gas bubbling are minimized, can be seen in Fig. 17. Convective mixing was minimized by not heating with the boiler or I.C. engine, and by loading the cold manure influent into the bottom of the digester tank. The mixing effect of gas bubbling was most likely minimized, since it is expected that most of the gas bubbling occurred above the accumulation of manure on the tank bottom. The cold manure was distributed slowly throughout the tank, drawing the overall temperature down as it mixed.

In contrast to Figure 17, the effect of loading the digester to the top is shown in Figure 18. In this case, mixing that resulted from convenction currents and gas bubbling was optimized. The cold manure was mixed by convection as it tended to settle toward the tank bottom, and was also mixed by gas bubbling during its downward motion. Once again, the boiler remained off, however, the cold manure almost completcly mixed intu the warm manure in only about six hours.

The indications from the studies and gas production data are that in-tank mixing equipment can be eliminated from dairy manure digestcr designs. Natural mixing from convection currents and gas bubbling can sufficiently mix the digester contents. More rapid and thorough mixing can be achieved if manure is loaded to the top of the digester, because the effects of convective mixing and gas bubbling are optimized. Problems of scum formation can be eliminated simply by keeping the $\%$ TS of the digester contents above the point at which scum layer formation ceases to be a problem. 


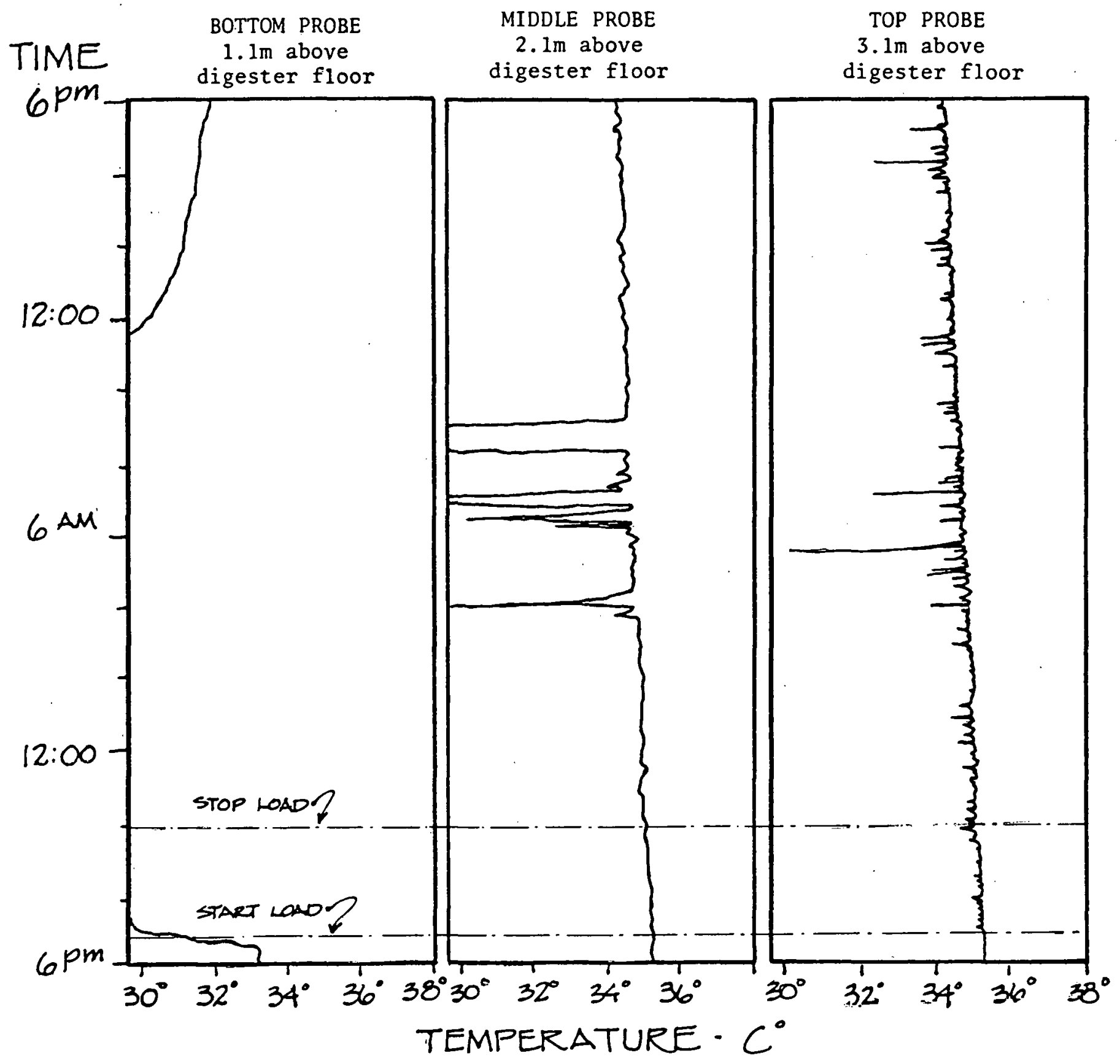

Figure 17

Temperature Probe Readings 
The elimination of in-tank mixing systems has a great impact on the economic feasibility of digestion. It reduces capital, energy, and maintenance costs. It also reduces the vulnerability inherent in having equipment inside the digester tank.

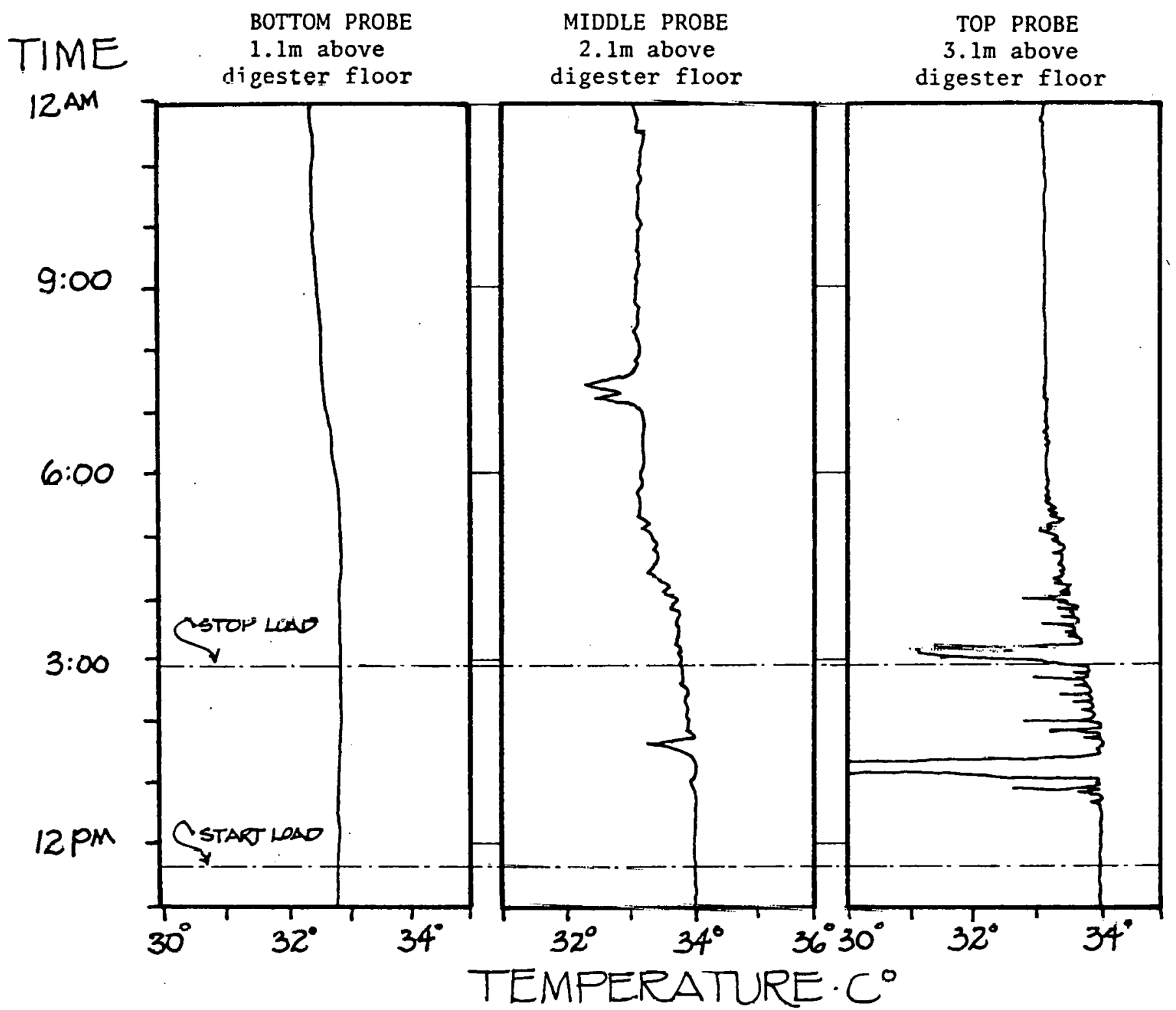

Figure 18

Temperature Probe Readings 
D. Gas Handling and Utilization

\section{Introduction}

Biogas has approximately $60 \%$ of the heating value of natural gas. It has various potential household and farm uses such as cooking, water heating, space heating, refrigeration, grain drying, irrigation pumping, food processing, and electricity generation. Its use as a vehicle fuel is limited by the difficulties of gas storage. Storage as a liquid requires expensive equipment, and storage as a gas requires large volume even at high pressure $(1.65 \mathrm{MPa})$. At present, farm-generated biogas utilization experience is meager, although biogas utilization at sewage treatment plants is relatively common.

\section{Gas handling performance}

The gas handling system at the Monroe digester differs little from the gas handling systems of municipal sewage treatment plants. The system is automated with pressure switches that control the flow of gas to the boiler, compressor, or flare as required. Gas is allowed to flow to the internal combustion engine as necessary by means of manual valves (Figure 19).

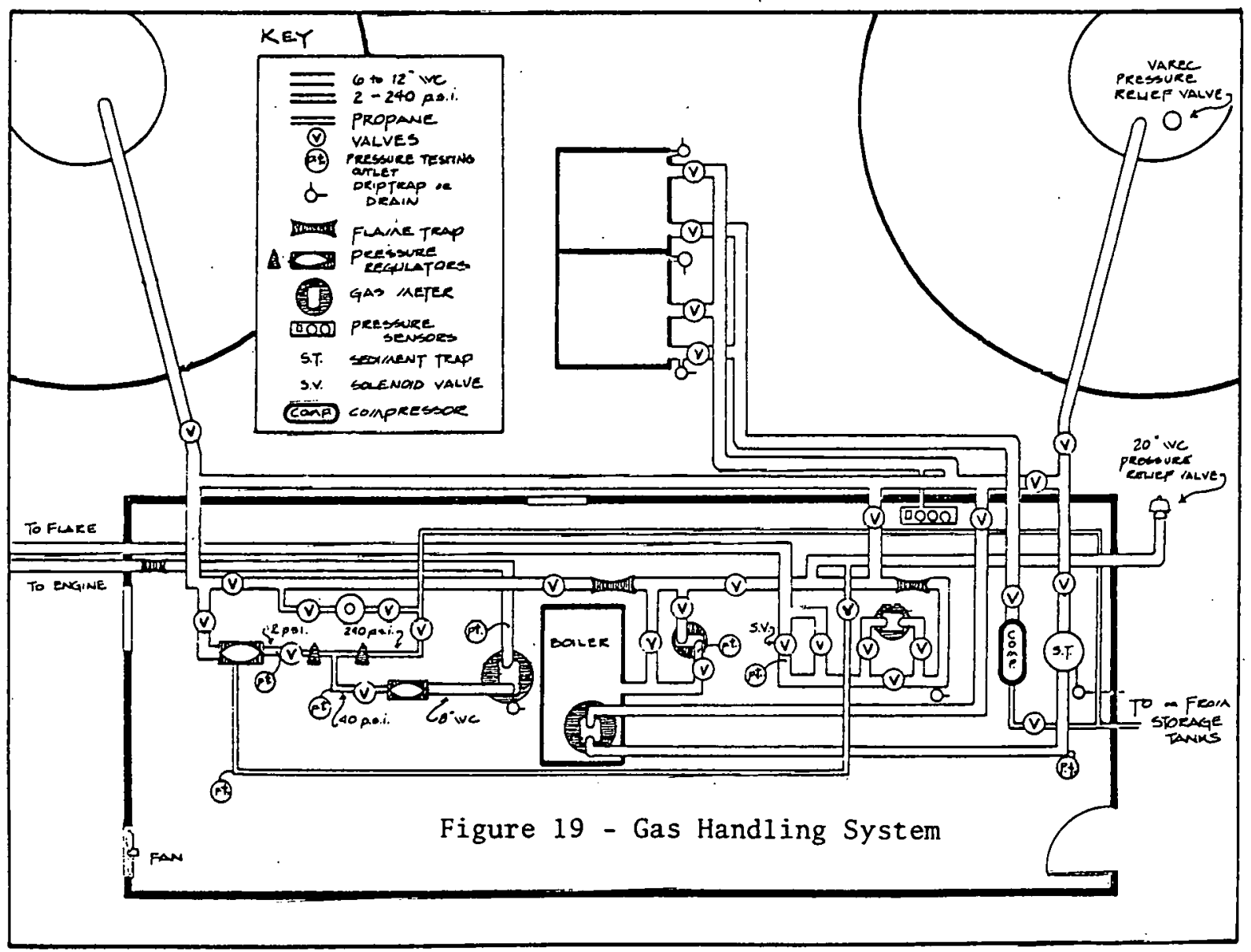


A number of unanticipated problems were encountered with the gas handling system during the start-up phase. The majority were due to the high moisture content of the gas. Upon correction of the problems, the gas handiing system functioned reliably and, with proper maintenance, presented no problems.

\section{Low p̈ressure systems}

The low pressure system includes all gas handling equipment except the compressor, storage tanks, high pressure piping, and pressure regulators. A low pressure handling system will be required on all digestion systems. The problems encountered in this system should be taken into consideration when designing a gas handling system.

Water condensate accumulation in the gas lines and meters caused numerous gas flow stoppages during the start-up phase of operation. The problem was solved by installing manually operated drip traps at low points in the lines and at the bottoms of meters. The drip traps are emptied daily, draining about 2 liters of water from the system each day. Installation of an adequate number and regular use of drip traps is essential to eliminate condensate blockages in a low pressure system.

During the first winter of operatiul, watcr condenstie froze in the gas lines and meters, stopping gas flow. Freezing was a particular problem at the first vilve downstream of the digester in the low pressure piping. This ball valve is a. line restriction and causes the gas to drop in temparature and pressure as it flows through. The gas at this point has its highest water vapor concentration, and the drop in temperature and pressure causes rapid condensation and enhances freezing in cold weather. Freezing problems were solved by moving the gas meters into the warm boiler room and insulating the gas lines outside. Particularly heavy insulation was placed around the ball valve that was usually open and did not need to be operated under nomil conditions. These measures were sufficient to prevent further freezing problems. It should be noted that freezing of gas handling equipment can be a very serious problem. Twice during the first winter, both the gas lines and the pressure relief valve at the digester top froze, causing pressure to build up in the tank. The overflow design of the effluent system provided back-up pressure relief since manure, and finally gas, was forced out the overflow as pressure in the tank increased. Had this back-up pressure relief not been available, rupture of the tank might have occurred. Back-up pressure relief is an important advantage of an overflow system. 
Three automatic pressure switches had to be replaced during two years of operation. The moisture content of the gas may have contributed to this relatively high failure rate. Another factor that may have contributed to rapid failure was that the pressure switches sensed the pressure by means of a narrow tube directly connected to the gas lines. When a switch opened, pressure in the lines would drop momentarily due to gas surging, and the pressure in the narrow tube would drop low enough to close the switch. The pressure in the tube would then build up quickly, and the switch would again open only to be closed again quickly as pressure dropped due to surging. This phenomena caused rapid opening and closing of the switch several times before the switch finally stayed open. The result was increased wear on the switch.

4. High pressure system

A high pressure system is: not a necessary component of a farm digester system, however, a high pressure storage system does present several advantages. Our system was designed to automatically repressurize the low pressure system to $1.2 \mathrm{kPa}$ should pressure fall below that point. This protects the digester tank from infiltration of air in case of a gas leak by maintaining positive gas pressure until the storage is depleted. It also protects the tank from implosion should the tank develop a leak below the slurry level and lose fluid. Gas storage capacity also proved to be an advantage during the digester shutdown. Biogas in storage allowed us to restart the digester with biogas to fuel the boiler. The trouble of converting the boiler to propane and then back to biogas, iwhen biogas production became adequate to fuel the system, liwas thus: avoided.

Problems were encountered in the high pressure (1650 $\mathrm{kPa}$ ) system due to grit, water, and oil in the gas lines. No drip traps were originally installed on the high pressure lines, and water and grit accumulated for over a year eventually causing the pressure reducers to malfunction. This problem was solved by taking apart and cleaning the pressure reducers, and regular draining: of: the water. by inserting a pressure gauge needle adaptor into a Pete's Plug. This removed water without depressurizing the lines. An oil leak in the compressor caused oil to be sprayed into the high pressure lines where it formed an emulsion with water in the orifices and diaphragms of the pressure reducers. The reducers malfunctioned causing the downstream low-pressure line to increase in pressure from $14 \mathrm{kPa}$ to $172 \mathrm{kPa}$, and gas was vented through a pressure relief valve. This resulted in a significant gas loss for about a week. Cleaning the emulsion from the lines and reducers returned the system to normal functioning. 
These experiences indicate the need for regular water removal from gas lines and a bi-yearly cleaning of the high pressure lines to remove grit and oil-water emulsion. The bi-yearly cleaning takes approximately four hours in a regular maintenance schedule. Our experience with moisture condensation in the gas lines led us to believe that a large amount of water had probably condensed in the storage tanks, however, only $0.6 \mathrm{~cm}$ of water was found at the low points of the tanks.

\section{Utilization}

Biogas was used at the Monroe digester to provide fuel for the heating system boiler, lab-trailer, and internal combustion engine. The original plan was to size the gas to fuel a boiler in the farm creamery, however, funds for pipeline construction were not available untıl the tall of 1979. Gas productilu in extess of needs at the digester site was flared. 'The digester boiler burned unscrubbed biogas. The only noticeable difference from burning natural gas was the need to clean sulfur deposits from the burner jets every six months.

The internal combustion engine and generator were installed as part of the original demonstration project. The purpose of the installation was to provide emergency back-up electricity for the creamery and milking operations. The engine is a Waukesha VRG 310 natural gas engine with a dual fuel Impco Mode1 200 carburetor. The engine is directly coupled to a Kato $40 \mathrm{kVA}$ (peak) generator. Engine cooling water can be circulated to the internal draft tube heat exchanger to provide digester heating. A Westinghouse D4S-7 kilowatt-hour meter was used to monitor the power generated.

The engine/generator was tested by wiring the generator to a $40 \mathrm{~kW}, 3$-phase $(3-13,3 \mathrm{~kW})$ resistive load. Resistive loading allowed the data to be read directly without correction for power factor; data taken with inductive loads must be corrected for power factors less than unity. The loading was variable from 6.37 to $41.7 \mathrm{~kW}$ in two steps. The engine/generator is rated at $40 \mathrm{~kW}$ and $23 \%$ efficiency based on its performance at full load running on propane; output is less for lower Btu fuels. As a consequence, the engine/generator produced only a little more than $25 \mathrm{~kW}$ before loading down below 60 cycles per second. This represents a capacity loss of about $37 \%$. Figure 20 shows the electrical conversion efficiency under various load conditions. The efficiency varied linearly over the $6 \mathrm{~kW}$ to $25 \mathrm{~kW}$ range tested. 


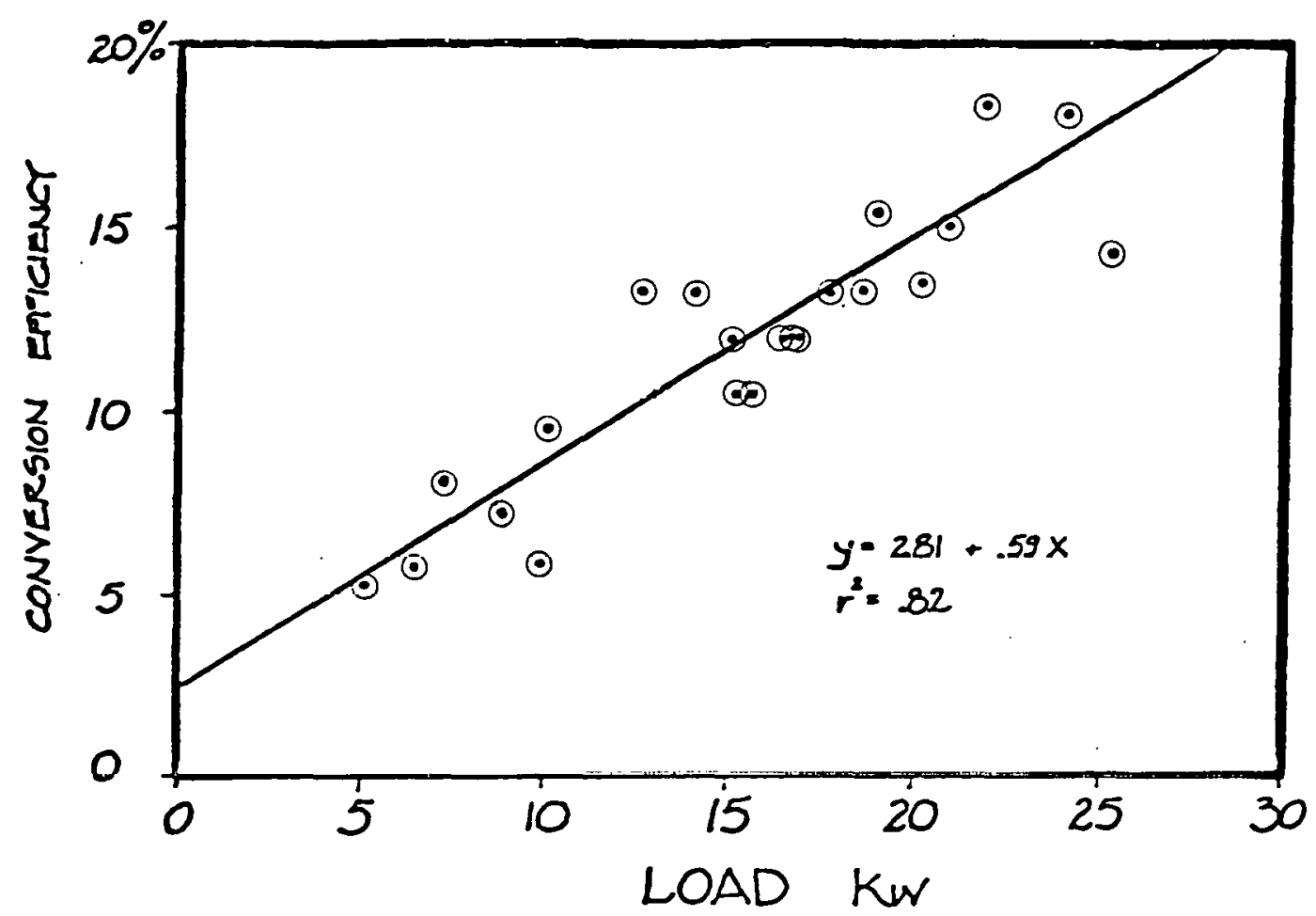

Figure 20 - Conversion Efficiency for Electrical Generation

Little information is available on piping farm generated biogas to a utilization site some distance from the digester as intended in the original plan. Experience at Monroe has shown that a pipeline should have drip traps to remove water condensate from the line to prevent blockages and freezing, shut-off valves to allow convenient maintenance and removal of equipment, as necessary, and a flame trap to protect the digester and gas storage for back-flow of flame through the line. The pipeline should be freeze protected either by burial or thermal insulation on above-ground sections. Burial of pipeline sections may make drip trap installation at all low points impossible, and sufficent pressure to move water through the line must be maintained in that case. Pressure taps should also be provided to allow troubleshooting of problems that might occur. Black iron pipe has traditionally been used for gas handling at sewage treatment plants. Internal corrosion is not generally a problem, however, black iron piping must be protected form external corrosion. Painting with rust-inhibiting paint suffices for above-ground piping. Buried sections of pipelines should be: 
1) coated with an appropriate bituminous coating or tape,

2) given cathodic protection, and

3) electrically insulated from above-ground sections.

Bituminous coatings are available from pipe vendors and protect the pipe from contact with corrosive chemicals. Cathodic protection can be provided by the sacrificial-anode method. The more cathodic of two metals contacting an electrolyte causes electrochemical attack of the more anodic metal. Magnesium anodes in contact with a buried pipeline will be selectively corroded, thus protecting the pipe. Usually, a small number of anodes, perhaps 1-3, are required, and the exact number depends on soil resistivity. The anodes should be inspected periodically, as they will completely corrode, leaving the pipeline unprotected after a period of years. Buried sections of black iron lines should also be electrically insulated from above-ground sections. Inadvertent grounding of the above-ground section might otherwise override the cathodic protection and accelerate corrosion of the buricd scction.

Galvanized pipe is not recommended for gas service because the galvanizing can flake off inside the pipe and plug the small orifices of crucial gas handling equipment, such as pressure regulators.

High density polyethylene pipe is often used for underground pipelines by gas utilities. This pipe has some excellent characteristics, including low frictional reisstance to flow and good resistance to chemica1s. It is usually cheaper both in mater:al and installation costs. but is somewhat more susceptible to damage by careless digging. The pipe is available in a range of pressure ratings up to 1.1 $\mathrm{MPa}$, and is a good substitute for black iron pipe.

The gas recirculation mixer at Monroe was plumbed with CPVC pipe which exhibits favorable high temperature-pressure characteristics. The pipe remains in exce1lent condition after two years of gas exposure. We experienced two gas leaks at welded fittings in these lines within 9-12 months after installation. This indicates the need for careful welding technique, if CPVC pipe is used for gas service.

A gas pipeline will be constructed at Monroe in the fall of 1979 to pipe gas approximately 1200 feet to the farm creamery where it will fuel a gas-fired boiler. 
The pipeline will consist of nominal $3.18 \mathrm{~cm}$ black iron pipe buried approximately $75 \mathrm{~cm}$ below ground. Corrosion protection will be provided by bituminous paint, magnesium anodes, and electrical insulation of above- and below-ground sections. The pipeline will be equipped with the necessary accessories, and working pressure will be aporoximatelv $345 \mathrm{kPa}$. Operation of this pipeline will provide useful experience in piping farm-generated biogas.

\section{Safety}

Biogas is no more dangerous than natural gas or propane; however, as with these other fuels, it should be used with the care due a material that can attain explosive concentrations in air. The two most important safety precautions are the avoidance of explosive mixtures of biogas with air and the prevention of sparks. Since biogas can only explode at concentrations from $9-23 \%$ by volume in air, enclosed areas where gas can accumulate are the most dangerous. Small leaks are almost impossible to prevent, therefore, good ventilation of enclosed areas is important. The pungent odor of biogas due to trace amounts of hydrogen sulfide is an advantage since it makes the nose a good leak detector. The Monroe digester is equipped with standard sewage treatment safety equipment, including flame traps, pressure relief valves, and an electronic gas detector. The safety equipment has functioned reliably for two years. The only problem has been occasional freezing of the pressure relief valve in winter, as mentioned earlier.

Inclusion of numerous shut-off valves in the gas handling system provided a convenient way to isolate meters, the boiler, and other equipment for removal and maintenance when required. Isolating with nearby valves allowed removal of equipment without introducing dangerous quantities of air into the gas lines.

In general, the human nose adequately detected a number of small gas leaks that occurred in the boiler house over the two-year operation of the plant. Soapy water, which bubbles when applied to a leaky fitting, provided a way to find the exact location of leaks. Hissing from large leaks could be heard immediately when the gas was turned on, if fittings did not seal properly during installations. 


\section{E. Start-up and Shutdown}

1. Overview

Start-up and shutdown of anaerobic digesters can be difficult, time consuming, costly, and dangerous. Certain wastes do not digest without great care. Severe weather conditions intensify labor requirements, and production outages can require expensive energy substitutes. Start-ups can be stalled by drugs or other chemicals in the substrate that may inhibit bacterial growth. Shutdowns are potentially dangerous if care is not taken to prevent explosive mixtures of methane and oxygen.

Desnite these complications, start-up of most dairy manure digesters is relatively easy due to the benign nature and outstanding acclimation characteristics of the substrate. The usual start-up procedure is to fill the digester almost completely with water, heat it to required temperature, and then begin loading, but at a lower rate than normal. After the period of approximately one retention time,2-4 weeks, the digester should be biologically stable, normal sized loadings can begin, and the start-up is over. Filling the tank with water initially eliminates the possibility of an explosive mixture of methane and oxygen that may result from possible biogas production contacting air not yet displaced in the tank. Reduced loading rates are preferred to minimize the risk of acids build-up in the tank that may inhibit methane formation.

Biological stability is reached when gas production begins to rise, and the digester acids level begins to fall. Either gas flow is monitored or the pH or Total Volatile Acids (TVA), are measured. If gas production does not rise after a typical start-up period, the acids level should be monitored daily. The pH should be rising, the TVA, after peaking, should be falling. If this is not happening, the digester has gone "acid" or "sour", meaning the digester must be shutdown and start-up procedures followed again, but more carefully.

Start-up failures are rare among dairy manure digesters. Normally, either too rapid loading and acids formation, or harmful chemicals are the cause. Failures of digesters in general may be due to a lack of seed material or buffering capability. Seed material containing a rich bacteria culture is used to initiate digestion in otherwise difficult to digest wastes. Buffering of a digester is used to minimize the harmful effect of acid formation before methane bacteria are able to reproduce and consume the acids.

Shutdown is typically required to remove sediment or scum layers that reduce 
digester efficiency, or to repair the heat exchanger or other tank interiors. Digester designs should leave provisions for easy entering of an emptied tank, especially for the removal of large quantities of sediment. Ample access to digester openings must be maintained.

To shutdown a digester, an inert gas such as nitrogen $\left(\mathrm{N}_{2}\right)$ or carbon dioxide $\left(\mathrm{CO}_{2}\right)$, is required to maintain positive pressure and prevent oxygen $\left(\mathrm{O}_{2}\right)$ from entering the tank while its contents are emptied by gravity or pump. A possible source of $\mathrm{CO}_{2}$ rich gas is internal combustion engine exhaust. Positive pressure prevents the tank from possibly imploding by pressure drop as the liquid is removed. Purging with an inert gas prevents $\mathrm{O}_{2}$ from entering the digester and forming an explosive mixture with methane.

\section{The Monroe Digester}

The Monroe digester was started up in September of 1977 . One of the two $189 \mathrm{~m}^{3}$ digester tanks were filled with $4 \%$ TS slurry over a five day period and then heated to $35^{\circ} \mathrm{C}$. Stabilization took 25 days, although digester heating began only halfway through this period. If the digester was at normal operating temperature from the start, this period would probably have been much shorter. The tank was not filled with water initially, since it was filled with slurry in just five days, and any methane production was considered insignificant. For dairy manure, both seeding and buffering are unnecessary, based on Monroe digester start-up experience.

The Monroe digester was shutdown in August 1979. The shutdown procedure was unique, in that a second unused digester tank was available to receive the digesting contents of the tank in use. This procedure eliminated the need for another start-up, since the exceptional biological stability of the substrate allows effective acclimation to either high or low loading conditions. Ordinarily, with a single digester, the contents would be removed to fields or a holding lagoon.

The contents were transferred, not because the digester exhibited a loss in performance or signs of needing repair, but for other reasons. Since the facility is used to conduct research, the second digester tank was provided with improved sampling capability. Carefully placed temperature probes were installed to more accurately determine boiler heating efficiency. Transfer also made it possible to simplify the loading and effluent piping arrangements for minimal pressure losses and clogging. Finally, it was also desireable to inspect the digester after two years of service for wear and to possibly upgrade its heating system design. 
The Monroe shutdown was actually more complicated, due to the transfer circumstances. The empty digester was initially purged with $\mathrm{N}_{2}$ to remove the $\mathrm{O}_{2}$. If enough $\mathrm{N}_{2}$ was available, the tank being emptied could be purged, while gas from the tank being filled would be vented. To conserve $\mathrm{N}_{2}$, however, the gas lines of the digesters were connected, and a slightly higher pressure was maintained in the digester being filled to prevent backflow of methane into it. Pressure in both tanks was monitored by manometer connections to independent gas lines. The content levels in the tanks were first allowed to equalize by gravity after opening a valve on a pipe that connected them. At this point, the contents of the first digester were drained to the effluent holding tank and then pumped into the second. 
IV. BIOLOGICAL PERFORMANCE

\section{A. Laboratory Testing}

A laboratory was established at the Monroe facility to monitor the health of the digester, and to note the impact of various loading and mixing regimes on biological activity. The substrate has proven to be remarkably stable. There have been no serious signs of stress, even with decreased mixing, temperature fluctuations, high loading rates, periods of no loading, and during a planned shutdown.

At the beginning of the project, digester contents were tested daily for pH, acidity, alkalinity, total volatile acids (TVA), percent total solids (\%TS), and percent volatile solids (\%VS). Once the system stabilized, the results of these tests became quite constant, and testing frequency was reduced to twice a week. Later in the project, acidity tests were discontinued and alkalinity and TVA were performed only once a week as $\mathrm{pH}$ remained relatively unchanged at 7.4. Raw manure influent from the start of the project has been tested daily for \%TS and \%VS for mass balance considerations. Recently, both raw and digested manure have been tested for chemical oxygen demand (COD) on a bi-weekly basis to establish typical reduction ratios. All tests were run according to the procedures of standard methods, with a slight modification in testing for total volatile acids.

\section{B. System Start-up}

Loading of a single digester at Monroe began on August 30, 1977. The digester was completely loaded over a 5-day period. Manure was scraped into the influent tank, diluted to $4 \%$ TS, and pumped into the digester. The boiler was not in service until September 15, and the contents remained at ambient temperature until that time. On September 19 , the digester reached $35^{\circ} \mathrm{C}$.

Biological monitoring was begun on September 9, 1977 (Figure 21). Total volatile acids (TVA) was $2000 \mathrm{mg} / \mathrm{L}$, alkalinity was $3300 \mathrm{mg} / \mathrm{L}$, and $\mathrm{pH}$ was 6.5 . The TVA peaked at $4000 \mathrm{mg} / \mathrm{L}$ on September 26 (alkalinity at $3000 \mathrm{mg} / \mathrm{L}$, and pH still at 6.5). Since the TVA dropped the next day, daily loading of the digester hegan on September 28. The TVA continued to drop to below $1000 \mathrm{mg} / \mathrm{L}$ by October 2 . 
START UP

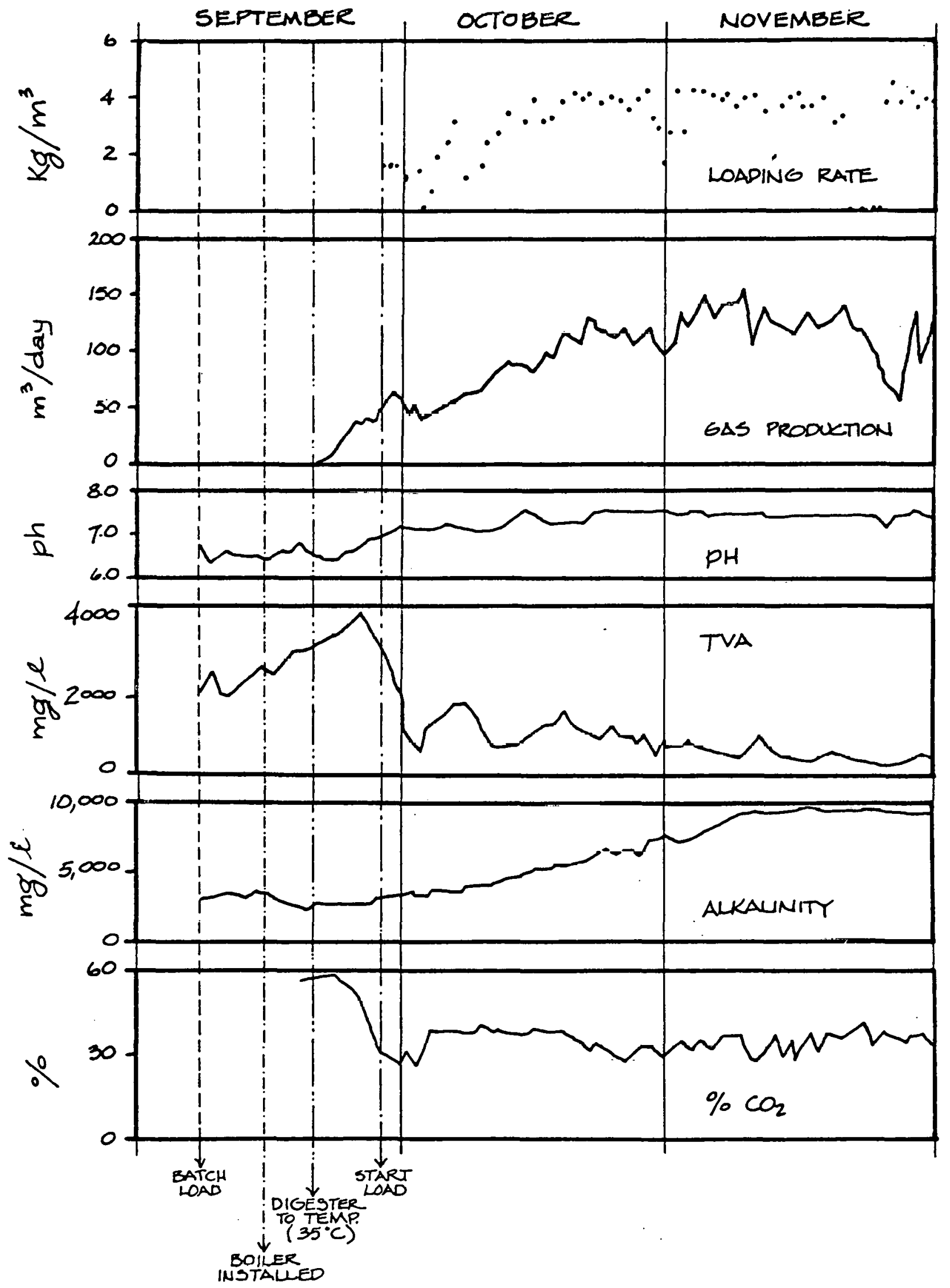

Figure 21 
Alkalinity and $\mathrm{pH}$ also rose to $3600 \mathrm{mg} / \mathrm{L}$ and 7.2 respectively by this date. Carbon dioxide $\left(\mathrm{CO}_{2}\right)$ in the biogas, consistently above $55 \%$ until September 23 , was down to $38 \%$ on October 4 . Through the month of October, the expected recovery pattern continued with a further decrease in TVA and increase in alkalinity and $\mathrm{pH}$. By November, these parameters had stabilized to those maintained throughout most of the digester's operation. The TVA stayed below $1000 \mathrm{mg} / \mathrm{L}$, alkalinity around $10,000 \mathrm{mg} / \mathrm{L}$, and $\mathrm{pH}$ near 7.4 .

The original digester loading schedule was developed by an experienced sewage treatment plant operator. The increased gas production that followed each increase in loading rate, and the absence of any biological stress led to increasing the loading rate more rapidly than originally planned, however. The planned final rate of $4 \mathrm{~kg} \mathrm{VS} / \mathrm{m}$ reactor at $8 \%$ TS was reached in seven weeks instead of the planned twelve weeks.

Increases in the loading rate would have continued, but numerous operational problems associated with winter freezing and flooding were encountered. A decision was made to hold the loading rate steady until those problems were resolved. Beginning in 1978, the loading rate was increased to loading all available manure at $10 \%$ TS (averaging $5-6.5 \mathrm{~kg} \mathrm{vS} / \mathrm{m}^{3}$ a day). Consequently, retention time has been as low as 12 days, although, it is normally 16 days. The change in the percent solids loaded required certain influent mixing modifications, but neither the higher rate or solids level had an adverse biological impact (Figure 22).

\section{Gas Production and Digestion Performance}

Gas production has gradually improved over the life of the digester primarily due to increases in production efficiency (Table 2 ). Although the digester stabilized biologically within a 3-month period following start-up, it appears that in the long term, there developed a more fully acclimated and efficient bacteria population, independent of operating parameters. Gas production averaged $178 \mathrm{~m}^{3}$ per day over the 23 months of the project including start-up, freezing and flooding, loading pump overhaul, and shutdown/transfer operations. Excluding the 5 months when these operations occurred, average gas production was $197 \mathrm{~m}^{3} /$ day: During the period of February through July 1979, it was $226 \mathrm{~m}^{3}$ a day. 
TABLE 2 Monroe Digester Performance, October 1977 to August 1979

\begin{tabular}{|c|c|c|c|c|c|c|c|}
\hline Month & $\begin{array}{r}\text { Gas } F \\
\left(\mathrm{~m}^{3} / \text { day }\right) \\
\end{array}$ & $\begin{array}{l}\text { Production } \\
) \quad\left(\mathrm{m}^{3} / \mathrm{kg} \text { Vs) }\right.\end{array}$ & $\begin{array}{c}\text { Boi?er Consumption } \\
\left(\mathrm{m}^{3} / \text { day }\right)\end{array}$ & $\begin{array}{r}\text { Dai } \\
\left(\mathrm{m}^{3}\right)\end{array}$ & $\begin{array}{l}\text { ily Load } \\
\left(\mathrm{kg} \mathrm{VS} / \mathrm{m}^{3}\right)\end{array}$ & $\begin{array}{c}\text { Digester } \\
\% T S\end{array}$ & $\begin{array}{l}\text {-6VS } \\
\text { Reduced }\end{array}$ \\
\hline $\begin{array}{l}\text { Oct } 77 \\
\text { Nov } \\
\text { Dec }\end{array}$ & $\begin{array}{r}93 \\
107 \\
147 \\
\end{array}$ & $\begin{array}{l}0.170 \\
0.165 \\
0.177\end{array}$ & $\begin{array}{l}62 \\
75 \\
64 \\
-\end{array}$ & $\begin{array}{r}9.4 \\
9.1 \\
10.4\end{array}$ & $\begin{array}{l}3.09 \\
3.68 \\
4.72 \\
\end{array}$ & $\begin{array}{l}3.5 \\
5.7 \\
6.4\end{array}$ & $26 \%$ \\
\hline $\begin{array}{l}\text { Jan } 78 \\
\text { Feb } \\
\text { Mar } \\
\text { Apr' }\end{array}$ & $\begin{array}{l}146 \\
198 \\
193 \\
216 \\
-\end{array}$ & $\begin{array}{l}0.172 \\
0.171 \\
0.185 \\
0.2303\end{array}$ & $\begin{array}{r}52 \\
79 \\
88 \\
91 \\
-\end{array}$ & $\begin{array}{r}9.5 \\
12.8 \\
11.9 \\
12.1\end{array}$ & $\begin{array}{l}4.85 \\
6.63 \\
5.99 \\
6.11\end{array}$ & $\begin{array}{l}7.3 \\
8.2 \\
8.1 \\
8.0\end{array}$ & 24 \\
\hline $\begin{array}{l}\text { May } \\
\text { Jun } \\
\text { Jly } \\
\text { Aug }\end{array}$ & $\begin{array}{l}221 \\
241 \\
201 \\
108 \\
\end{array}$ & $\begin{array}{l}0.196 \\
0.216 \\
0.241 \\
0.236\end{array}$ & $\begin{array}{l}88 \\
73 \\
58 \\
37 \\
-\end{array}$ & $\begin{array}{r}12.5 \\
12.1 \\
9.3 \\
5.4\end{array}$ & $\begin{array}{l}6.51 \\
6.45 \\
4.84 \\
2.66\end{array}$ & $\begin{array}{l}7.8 \\
7.9 \\
8.2 \\
7.7 \\
-7.7\end{array}$ & 25 \\
\hline $\begin{array}{l}\text { Sep } \\
\text { Oct } \\
\text { Nov } \\
\text { Dec }\end{array}$ & $\begin{array}{r}183 \\
144 \\
145 \\
154\end{array}$ & $\begin{array}{l}0.208 \\
0.252 \\
0.242 \\
0.233\end{array}$ & $\begin{array}{l}74 \\
68 \\
92 \\
90 \\
\end{array}$ & $\begin{array}{r}10.0 \\
5.5 \\
7.3 \\
7.7\end{array}$ & $\begin{array}{l}5.13 \\
3.35 \\
3.53 \\
3.90\end{array}$ & $\begin{array}{l}7.7 \\
7.8 \\
7.2 \\
7.3 \\
.7 .3\end{array}$ & 28 \\
\hline $\begin{array}{l}\text { Jan } 79 \\
\text { Feb } \\
\text { Mar } \\
\text { Apr }\end{array}$ & $\begin{array}{l}108 \\
206 \\
234 \\
230 \\
-\end{array}$ & $\begin{array}{l}0.220 \\
0.220 \\
0.217 \\
0.237\end{array}$ & $\begin{array}{r}85 \\
98 \\
104 \\
-\quad 80 \\
\end{array}$ & $\begin{array}{r}6.1 \\
10.2 \\
12.2 \\
9.6\end{array}$ & $\begin{array}{l}2.90 \\
5.54 \\
6.42 \\
5.79\end{array}$ & $\begin{array}{l}6.6 \\
6.7 \\
6.9 \\
8.2\end{array}$ & 34 \\
\hline $\begin{array}{l}\text { May } \\
\text { Jun } \\
\text { J1y } \\
\text { Aug }\end{array}$ & $\begin{array}{l}245 \\
218 \\
224 \\
132\end{array}$ & $\begin{array}{l}0.233 \\
0.245 \\
0.193 \\
0.238\end{array}$ & $\begin{array}{l}77 \\
68 \\
70 \\
44\end{array}$ & $\begin{array}{r}11.1 \\
9.1 \\
11.1 \\
6.2\end{array}$ & $\begin{array}{l}6.28 \\
5.33 \\
6.97 \\
3.23\end{array}$ & $\begin{array}{l}7.8 \\
8.1 \\
9.0 \\
7.9\end{array}$ & 30 \\
\hline
\end{tabular}

* Low production during these months was due to:

a) Oct, Nov 77--the start-up procedure of loading low solids of 4-8\% TS.

b) Aug 78-an 11 day outage of the loading pump for major repairs.

c) Jan 79--a 15 day period of freezing temperatures and no scraping.

d) Aug 79--a 14 day digester transfer period of no loading. 
operating DATA nOR METHANE DIGESTER
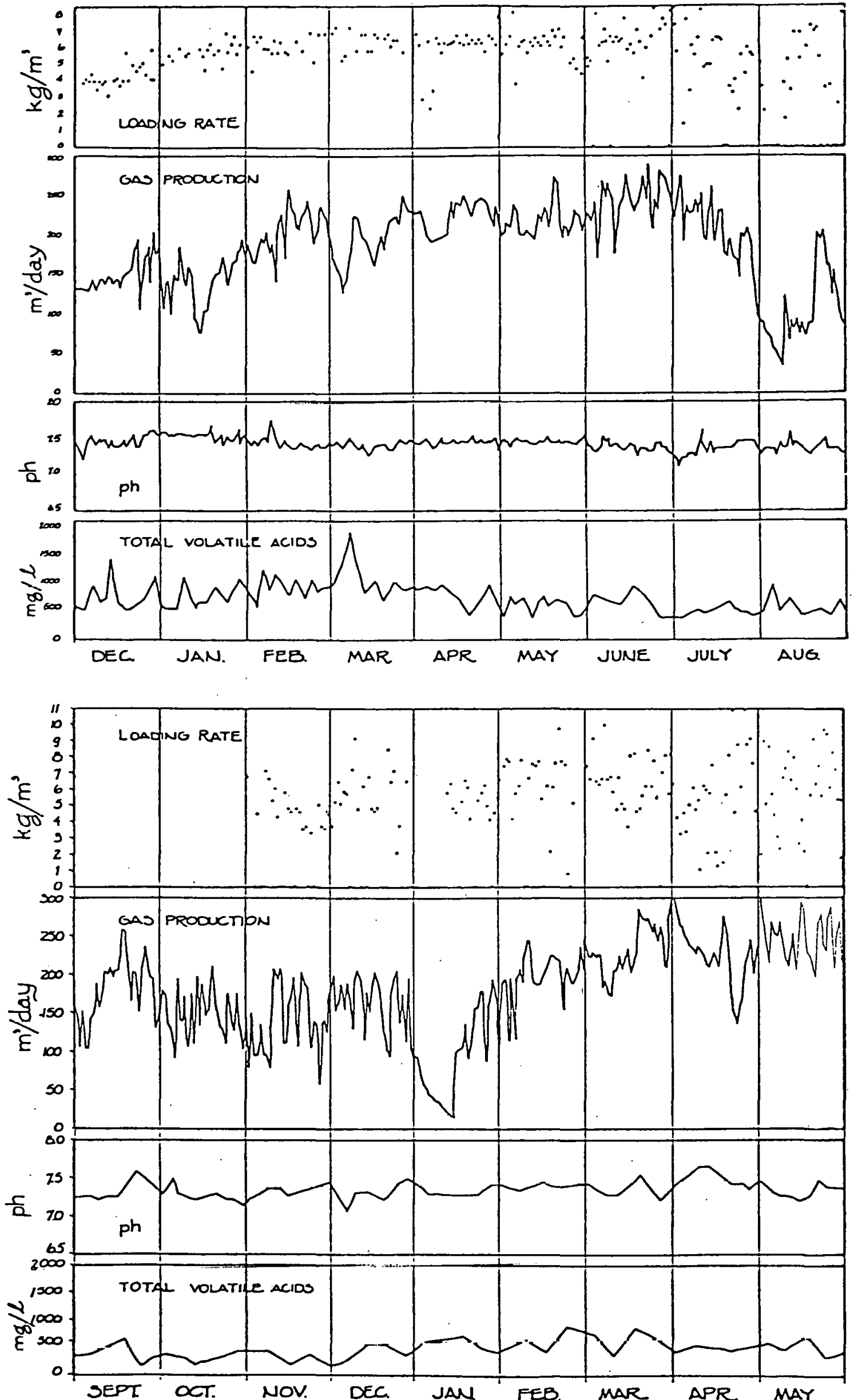
Gas production efficiency for the first 11 months of operation averaged $0.194 \mathrm{~m}^{3}$ per $\mathrm{kg}$ VS added, for the last 12 months, it was $0.228 \mathrm{~m}^{3} / \mathrm{kg}$ VS added, an $18 \%$ improvement. From April 1979 to the present, excluding July, this figure has averaged $0.238 \mathrm{~m}^{3} / \mathrm{kg}$ VS added. In July 1979, higher solids were loaded up to $12.5 \% \mathrm{TS}$, as an experiment to further reduce the digester heat demand and to document mixing and pumping requirements at higher solids levels. The solids in the digester rose to $9.0 \%$ TS, usually maintained at $8.0 \%$ TS. As a result, the gas production efficiency fell from 0.245 in June to 0.193 in July $\left(\mathrm{m}^{3} / \mathrm{kg}\right.$ VS added). It is not known whether the high solids level in the digester or the high loading rate of $7.0 \mathrm{~kg} \mathrm{VS} / \mathrm{m}^{3}$ digester volume inhibited gas production during this mullch.

The \%V reduced for the first 11 months of operation averaged 25\%, while for the last 12 months it was over $30 \%$. This improvement closely correlates with the gas production efficiency increase noted above, and is attributed to greater acclimated bacteria with time.

Influent and effluent samples were analyzed for COD over the period from April to July 1979. They averaged $82,000 \mathrm{mg} / \mathrm{L}$ and $49,000 \mathrm{mg} / \mathrm{L}$, respectively. Average COD reduction in the digested effluent was $40 \%$ on a volume basis and $30 \%$ on a weight basis.

\section{System Shutdown}

Transfer of the contents from one digester to the other was made on August 13, 1979. This was done primarily to utilize new and improved monitoring devices on the second digester, to make modifications to existing piping, and to inspect the first digester after two years of operation. Loading of the first digester ended on August 1, and began again with the second digester on August 16 . Heating of the digester was also discontinued on August 1 to conserve gas for start-up, and to help keep gas production low.

On August 16, the digester temperature was down to $27^{\circ} \mathrm{C}$, and gas production was approximately $17 \mathrm{~m}^{3} /$ day, about $7.5 \%$ of normal. TVA remained unchanged, alkalinity, and $\mathrm{pH}$ each dipped slightly, but hardly significantly, throughout the cool down and transfer procedure (Figure 23). On August 14, they measured 360,7100 , and 7.2 , respectively. In addition, recovery of gas production was exceptionally fast. By August 24, it was $212 \mathrm{~m}^{3} /$ day, at which point the biological parameters had already stabilized. 


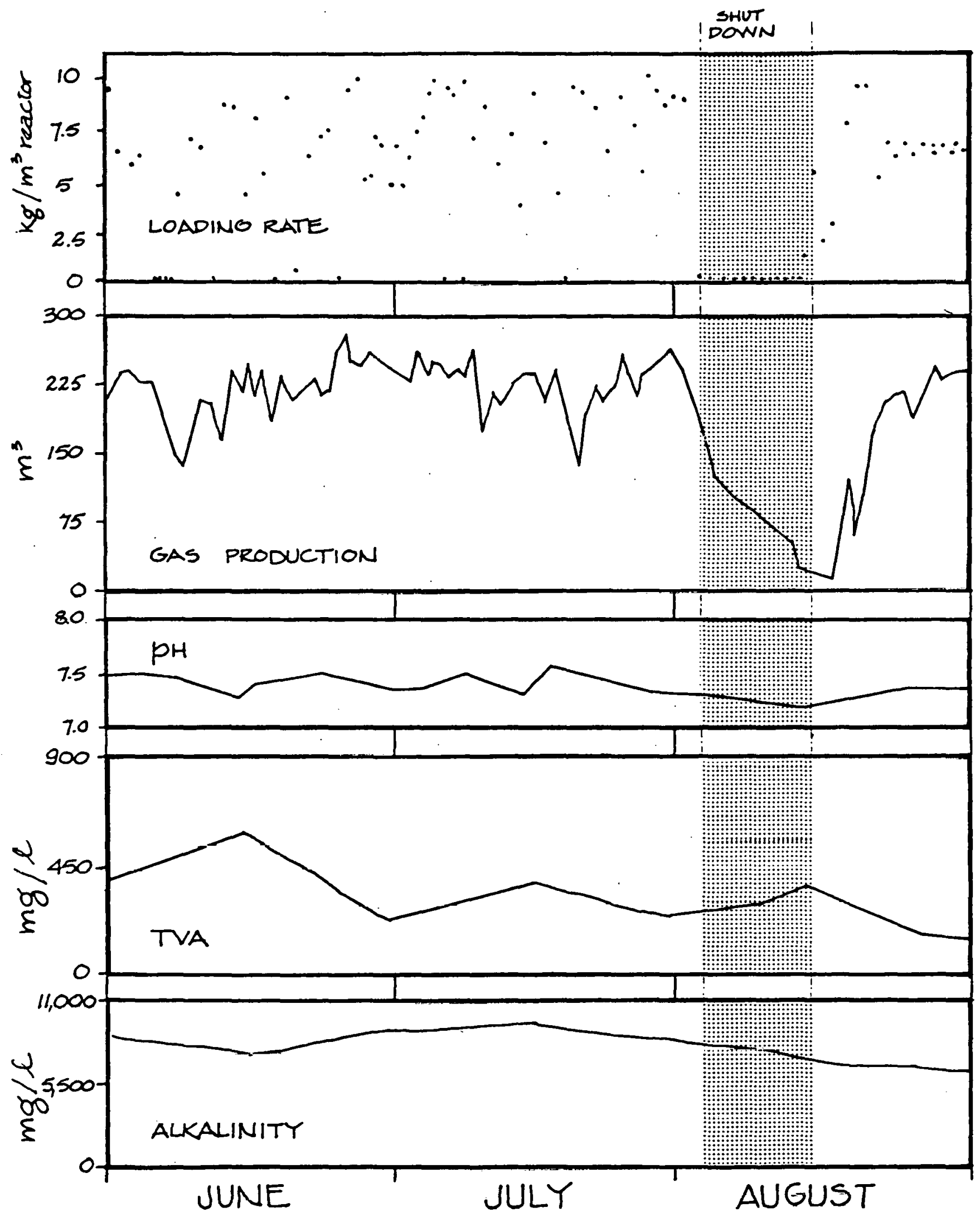

Figure 23

Digester Performance during System Shutdown 
The transfer procedure was similar to two other periods of non-loading and minor biological stress. The first was for 11 days when the loading pump was out of service for repairs in late July and early August of 1978. The other was for 15 days during an extreme freeze in late December and early January,of 1978/79. In each case, the bacteria population of the digester exhibited exceptional biological stability, noted by a rapid recovery upon resumed feeding.

\section{E. Biological Stability}

Digestion of dairy manure has presented none of the clirunic biological stress that has plagued municipal digesters. In municipal plants, the material fed may differ significantly from day to day, and may contain chemicals which either inhibit or are lethal to the bacteria required for methane production. With a farm digester the manure fed does not change dramatically and the addition. of harmful chemicals can be prevented.

This stability makes digestion of farm manures more feasible, since a farmer need not be concerned with monitoring the biological health of the system. Furthermore, the bacteria demonstrate extreme resistance to stress, especially in the recovery from periods of non-feeding which is of great benefit should major repairs and temporary shut-down become necessary. As a result, the lengthy and involved process of a fresh start-up can be avuided. 


\section{v. NET ENERGY}

\section{A. Overview}

The Monroe digester produced a steady supply of fuel gas with $60-65 \%$ of the heating value of natural gas during 24 months of operation. The gas production process required energy inputs in the forms of heat and electricity. Gas and electric meters measured energy production and inputs to provide data for an energy evaluation of the system. The net energy is the total gas energy output minus the energy inputs required to operate the system.

\section{B. Gas Production and Utilization}

Monthly gas production varied over a wide range during the 24 months of operation (Table 3). Gas production varied approximately linearly with the manure loading rate from month to month (Fig. 24). Thus, variation in loading rates had a greater effect on gas production than variation in microbiological efficiency.

During several months when the digester did not receive all the manure from the 180-head herd, and during periods of nonloading, the full potential for gas production was not realized. The overall gas production rate average was about $178 \mathrm{~m}^{3} /$ day given the loading rate reductions. There were two long periods during which the loading rate was consistent and included all the manure from the herd, February-June 1978, and February-July 1979. During these periods gas production averaged $214 \mathrm{~m}^{3} /$ day and $226 \mathrm{~m}^{3} /$ day respectively. These figures more accurately represent the gas production potential of the Monroe digester than the overall average.

The gas output of the digester was used to fuel the boiler for digester heating, run the internal combustion engine for electricity generation, and supply fuel for heating and cooking in the $1 \mathrm{ab}$. These uses consumed about $47 \%$ of the gas; the remainder was flared. The original plan was to use the net gas output to fuel a boiler in the farm creamery, however, funds to construct a gas pipeline to the creamery were not available until the fall of 1979. At this writing, construction of the pipeline is not yet complete.

\section{Energy Inputs}


the digester contents at $35^{\circ} \mathrm{C}$. This requirement consumed about $44 \%$ of the total gas production over 23 months. A monthly tabulation of boiler gas consumption is given in Table 3 .

Other energy requirements include electrical energy for digester mixing, and mixing and pumping the influent. The Monroe digester was designed to be continuously mixed by a recirculation blower based on experience at sewage treatment plants. During the first three months of operation, the blower was run continuously, consuming about $180 \mathrm{KWH} / \mathrm{day}$, which represented $90 \%$ of the total electrical demand of the system. Intermittent mixing was investigated in order to reduce electrical consumption and equipment wear. Mixing was gradudlly reduced with no resulting decrease in gas production. From May $19 / 8$ through early Masili 1979, the blower was operated only during digester loading. Mixing was completely stopped on March 6, 1979; gas production was not affected over the following six months. From March through August, the only electrical energy requirement was the energy needed to $\mathrm{mix}$ and load the influent slurry. This requirement averaged about $20 \mathrm{KWH} /$ day. Electricity consumption is shown graphically in Fig. 25.

\section{Net Energy Evaluation}

The most dramatic improvement in net energy was the elimination of blower use resulting in a $90 \%$ electricity demand reduction. Durling llie first five months of digester operation, net energy was also improved by increasing the solids in the influent loaded from $4 \%$ to $10 \%$ TS. Since the volume loaded remained roughly the same, in effect this change represents an increase in the quantity of solid material loaded. With heat demand held constant, this improved the net energy by enhancing gas production.

Later in the project, an increase from $10 \%$ to $12 \%$ TS was made with no increase in the quantity of solids loaded but with a reduction In lie dilluint of watcr added. This procedure resulted in a reduced digester heat demand and a small increase in retention time. The improvement in net energy, however, was unable to be quantified due to constantly changing ambient and operating conditions.

Net energy for the 23 months of digester operation is shown in Fig. 26. Low loading rates from August 1978 through January 1979 with resulting low gas production affected net energy results for those months. Net energy yield was about 56\% for the best digester performance period, February 1979-July 1979. For the twelve months including the best performance period, August 1978-July 


\begin{tabular}{|c|c|c|c|c|}
\hline Month & $\begin{array}{l}\text { Gas } \\
\text { Production } \\
\mathrm{m}^{3} / \text { day }\end{array}$ & $\begin{array}{l}\text { Daily Load } \\
\mathrm{KgVS} / \mathrm{m}^{3}\end{array}$ & $\begin{array}{l}\text { Boiler } \\
\text { Consumption } \\
\mathrm{m}^{3} / \text { day }\end{array}$ & $\begin{array}{l}\% \text { Total Gas } \\
\text { Production Consume } \\
\text { By Boiler }\end{array}$ \\
\hline *Oct 77 & 93 & 3.09 & 62 & 67 \\
\hline${ }^{*}$ Nov & 107 & 3.68 & 75 & 70 \\
\hline Dec & 147 & 4.72 & 64 & 44 \\
\hline Jan 78 & 146 & 4.85 & 52 & 36 \\
\hline Feb & 198 & 6.63 & 79 & 40 \\
\hline Mar & 193 & 5.99 & 88 & 46 \\
\hline Apr & 216 & 6.11 & 91 & 42 \\
\hline May & 221 & 6.51 & 88 & 40 \\
\hline June & 241 & 6.45 & 73 & 30 \\
\hline July & 201 & 4.84 & $58^{\circ}$ & 29 \\
\hline *Aug & 108 & 2.66 & 37 & 34 \\
\hline$-\cdots---$ & -------- & $\cdot--------1$ & $-\cdots---\cdots$ & - \\
\hline Sept & 183 & 5.13 & 74 & 40 \\
\hline *0ct & 144 & 3.35 & 68 & 47 \\
\hline${ }^{*}$ Nov & 145 & 3.53 & 92 & 63 \\
\hline${ }^{*}$ Dec & 154 & 3.90 & 90 & 58 \\
\hline$-\cdots---$ & $\cdots-\cdots-\cdots$ & $-\cdots--\cdots-\cdots$ & $--m-------$ & 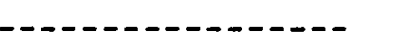 \\
\hline * Jan 79 & 108 & 2.90 & 85 & 79 \\
\hline Feb & 206 & 5.54 & 98 & 48 \\
\hline Mar & 234 & 6.42 & 104 & 94 \\
\hline Apr & 230 & 5.79 & 80 & 35 \\
\hline May & 245 & 6.28 & 77 & 31 \\
\hline June & 218 & 5.33 & 68 & 31 \\
\hline July & 224 & 6.97 & 70 & 31 \\
\hline *Aug & 132 & 3.23 & 44 & 33 \\
\hline
\end{tabular}

* Low production during these months was due to:

a) Oct, Nov 77--the start-up procedure of loading low solids of 4-8\% TS.

b) Aug 78--an 11-day outage of the loading pump for majnr repairs.

c) Oct-Dec 78--low loading rates resulting from incomplete scraping.

d) Jan 79--a 15-day period of freezing temperatures and no scraping.

e) Aug 79--a 14-day digester transfer period of no loading. 


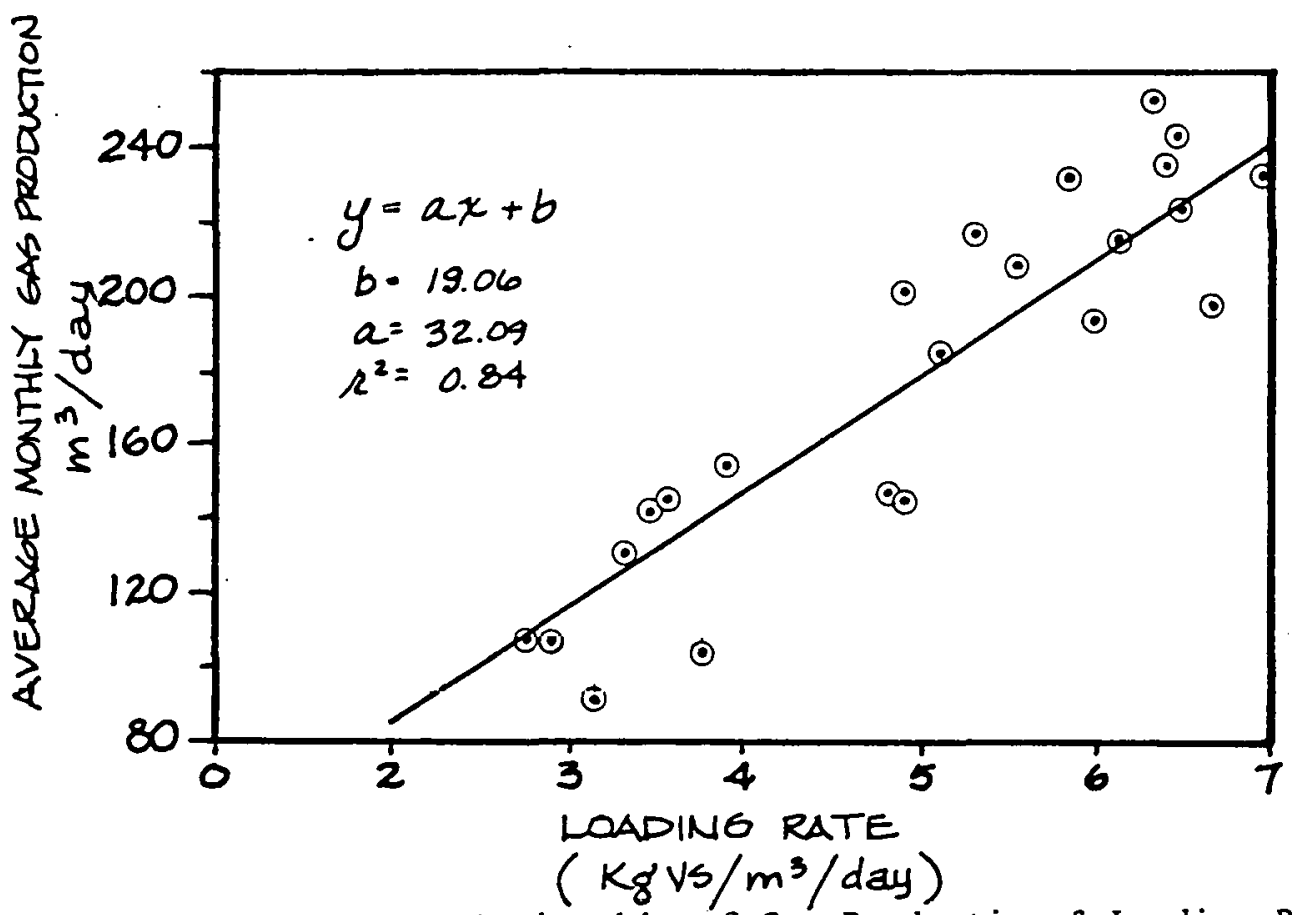

Figure 24 - Relationship of Gas Production \& Loading Rate

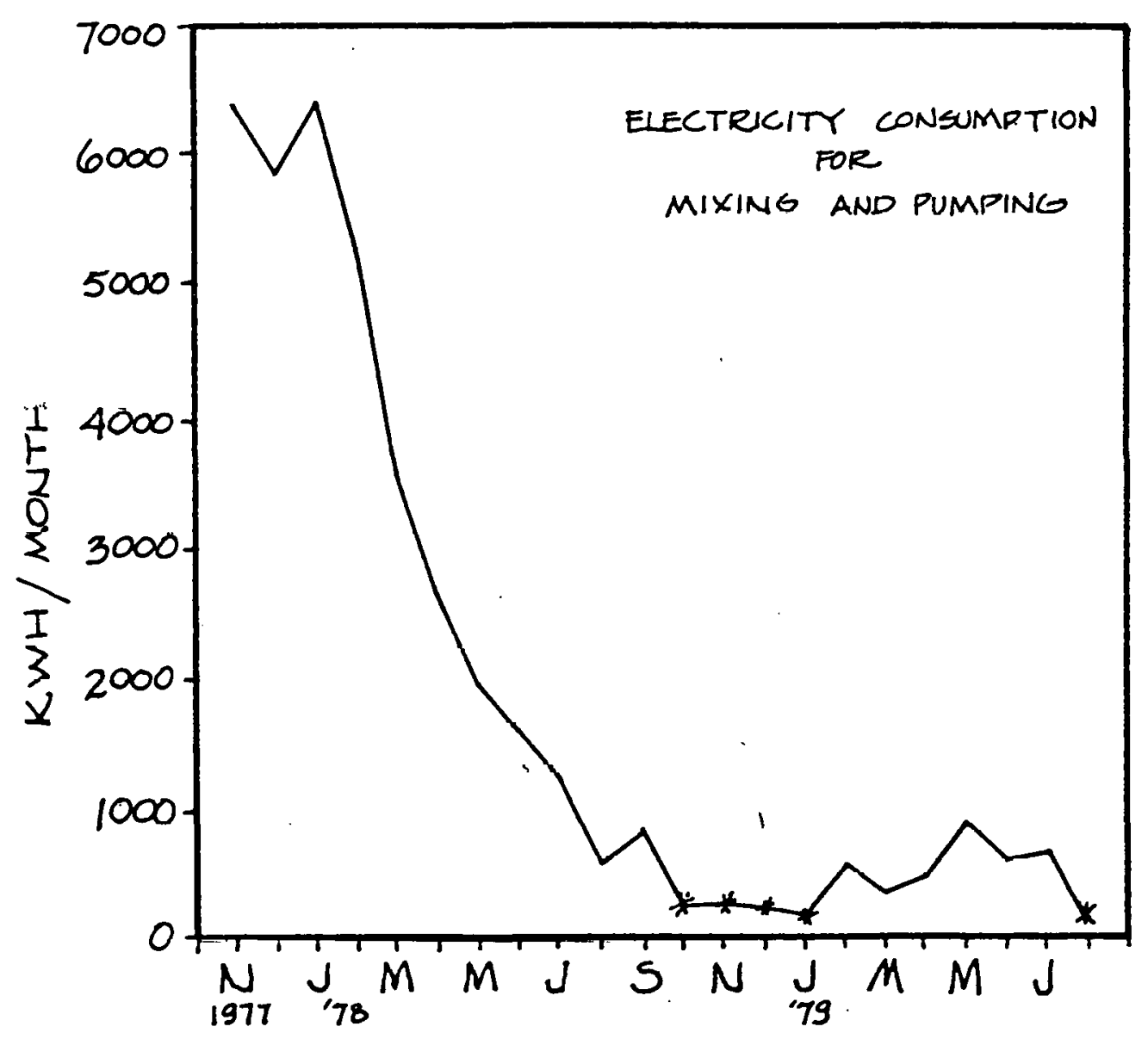

MONTHS

* electrical consumption low due to low loAding rates

Figure 25 - Electricity Consumption 
NET ENERGY

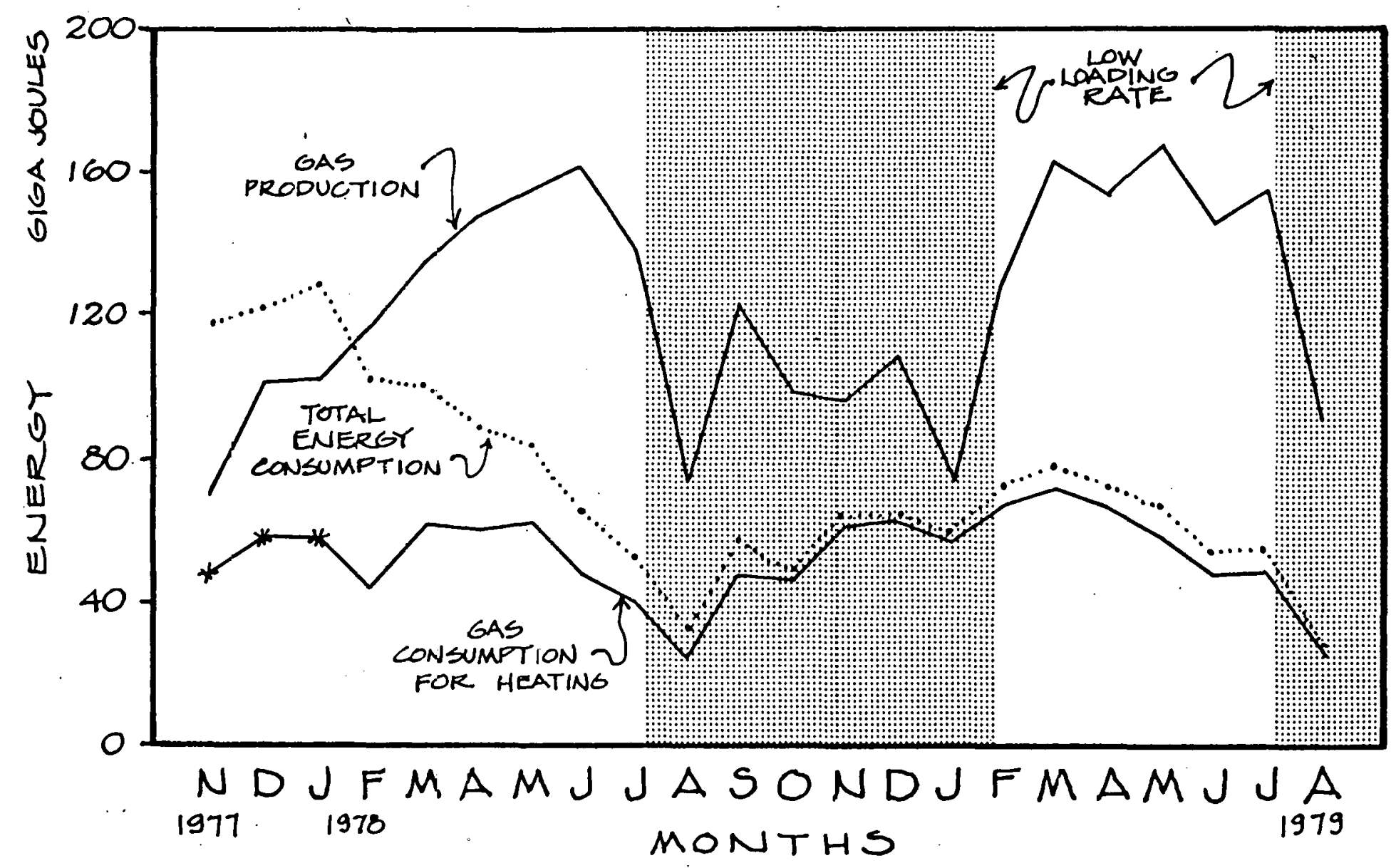

* corrected for use of engine cooling water for digester heating

NOTE: ELECTRICAL ENERGY IS CALCULATEO@II MEOA JOULE/KWH TO ACCOUNT FOR CONVERSION EFFICIENCY OF CENTRAL STATION GENERATION

Figure 26 - Net Energy 
1979, net energy yielded about $51 \%$. Since these months included the six months of low loading rates, an estimate of the annual potential net energy of the Monroe system is probably close to the best six months performance, $56 \%$ of the gross gas production.

The Monroe system is not yet at optimum net energy as opportunities for energy savings still exist. The most promising is improving the efficiency of the heat delivery system. It was observed during the winter of 1978-1979 that the boiler consumes excessive quantities of gas, up to $10 \%$ of daily gas production, just to keep itself up to temperature in cold weather. Installation of a flue damper valve has potential to save a significant portion of this gas. 


\section{ECONOMICS}

An economic analysis provides a valuable decision making tool for examining an energy producing technology. In general, it is the task of an economic analysis to assess the costs associated with a given output and to allow a comparison to other means of achieving similar ends. A secondary task of this analysis should be to provide insight that allows trade-offs between various design options. A final goal of an analysis of this type is to provide aid in designing policies and incentives that would encourage the use of a socially desirable technology.

While assessing the economics of anaerobic digestion technology sized for farm scale operations and resources, the economic analysis has some special requirements and problems. The methodologies used for evaluating energy producing technologies are often adapted from traditional analysis conducted by utilities. or private energy conglomerates to evaluate alternatives for central energy production. This style of analysis is not as applicable to small-scale decentralized technologies such as anaerohic digestion. There are soverel-immnrtant anomalies:

1) The consumer of energy produced by anaerobic digestion is also the producer. The financing methods and acceptable rates of return are very different for a farmer or consumer than a utility.

2) The utility assumes that a single economies of scale curve can be drawn for a given technology (e.g., a thermal power plant). For anaerobic digestion, a series of curves would be available depending on the design trade-offs, farm size operation, and the sophistication of the cxisting manure laduling system.

3) The farmer will experience a rising cost of competitive energy (electricity, natural gas, oil). Since these are rising much faster than inflation, the investment decision and, indeed, the long-term rate of return on the investment capital will be strongly influenced by the rate of energy cost increase.

4) The farmer is faced with rapid inflation in all costs. The value of any capital investment will increase over time. Even if energy costs rise at the rate of inflation, a capital investment that produces a benefit will ultimately be a good investment as the value of money falls.

5) Anaerobic digestion has other non-quantifiable benefits such as pollution control, odor control, increased ease in manure 
handling, and increased fertilizer value of the manure effluent. While it is difficult to assign economic value to these benefits, they will be factors in a farmer's investment decision beyond the value of the energy produced. Furthermore, the value of the investments will vary from farm to farm, making an a priori analysis of them essentially impossible at this level of generality.

For this report, an economic model has been developed and used that overcomes many of the difficulties of present inappropriate economic methodologies for evaluating farm scale anaerobic digestion. The economic model uses standard life cyclc cost formulas for computing the price of energy nccessary to cover all associated costs (See Appendix 2). The analysis balances the capital costs, the operating and maintenance costs, tax benefits, interest rates, and fuel escalation costs against the energy produced over the life of the facility. It also includes options for both owner financing and utility financing.

This economic model provides the flexibility to examine the impact to varying parameters such as financing options, capital costs, inflution rates, interest rates, and capital credits. This flexibility allows an evaluation of how to optimize the economic return from a system, as well as comparing the cost of energy produced from this technology to the cost of energy from other technologies.

In the analys1s, two finaneing options are examtned. One system is financed by a farmer, and the other is financed by a utility as part of its new elcctrical generating capacity. Within each of these financing options, both digestion systems that include manure handling components and those that are an expansion of existing manure handling systems, are examined. Any system can be evaluated for producing gas or producing electricity. This effects a system's capital cost, maintenance costs and operating costs. Most options are examined at both two hundred and four hundred head dairies. Because of the difficulty of assigning a cost of labor to a farm operation that does not require hiring a full-time operator, the economic information is presented for both.a labor cost of $\$ 4.00$ per hour, raised with the rate of inflation, and for no labor costs. One additional system is evaluated for an owner-built system at the 200-head size. All options are evaluated with no credits taken for other benefits, and assuming all the energy produced is used. The other assumptions common to all options are presented in Table $\underline{4}$. 
Table 4: Life Cycle Assumptions

1. Inflation

2. Fuel Escalation

3. Interest/Opportunities Cost

4. Life

5. Credits on Capital

6. Tax Rate (margina1)

7. Competitive Energy Costs

8. Efficiency of electricity Production
$10 \%$

$13 \%$

$12 \%$

20 years

20\% Investment Tax Credit $\$ 3,500$ Clean Water Act Credit (for farmer financed systems that include manure handling)

0.2

$\$ 3.69 /$ GigaJoule

$\$ 0.04 / \mathrm{kwH}$

$20 \%$

For a farmer financed system, the interest rate on the capital investment is assumed to be $12 \%$. The annual payment is computed by standard mortgage interest formulas. For the utility financed system, a different method is used. Utilities allow two sorts of capital costs, the first being a rate of return or profit on their invested capital (equity), and the second, cost of the capital borrowed (debt).

The output and cost assumptions that vary in different options are listed in Table 5. lhese include energy production, capital costs, and operating and maintenance costs. The capital costs vary for the following reasons. If a system produces gas as the primary output, no engine generator is required. If electricity is the primary output, the need for a boiler is eliminated. If manure handling is not included, the costs of the manure handling pump, the influent tank, and the manure handling plumbing is eliminated, and the labor costs are reduced to reflect only digester operating labor, as distinct from manure handling. For the site-built system, the labor construction costs are reduced and the profit for the company providing the packaged system is eliminated. Maintenance costs reflect need to completely replace each piece of equipment once during the 20-year life, and to acronut for the inflation that would occur in the costs over 20 years. 
Table 5: Energy Outputs, Capita 1, Operation and Maintenance Costs for Various Digestion Systems

\section{Head System}

With manure handling Without manure handling

gas elec gas

\begin{tabular}{lrrrr} 
Net Output & $1108 \mathrm{GJ}$ & $93.1 \mathrm{Mwh}$ & $1108 \mathrm{GJ}$ & $93.1 \mathrm{Mwh}$ \\
Capital Cost & 60,514 & 64,900 & 55,114 & 59,500 \\
$\begin{array}{l}\text { Operator Cost } \\
\text { (1abor) }\end{array}$ & 1,460 & 1,460 & 876 & 876 \\
Maintenance Cost & 920 & 1,000 & 770 & 850 \\
\hline
\end{tabular}

\section{Head (Site-built) System}

With manure handling Without manure handling

gas

elec

gas elec

$\begin{array}{lrccc}\text { Net Output } & 1108 \mathrm{GJ} & 93.1 \mathrm{MwH} & 1108 \mathrm{GJ} & 93.1 \mathrm{MwH} \\ \text { Capita1 Costs } & 50,415 & 54,900 & 45,114 & 49,500 \\ \begin{array}{l}\text { Operator Cost } \\ \text { (1abor) }\end{array} & 1,460 & 1,460 & 876 & 876 \\ \text { Maintenance Cost } & 920 & 1,000 & 770 & 850\end{array}$

\section{Head System}

With manure handling Without manure handling

\begin{tabular}{lcccc}
\hline & gas & elec & gas & elec \\
\hline Net Output & $2216 \mathrm{GJ}$ & $186.2 \mathrm{MwH}$ & $2216 \mathrm{GJ}$ & $186.2 \mathrm{MwH}$ \\
Capital Cost & 91,100 & 106,810 & 84,700 & 99,910 \\
$\begin{array}{l}\text { Operator Cost } \\
\text { (1abor) }\end{array}$ & 2,190 & 2,190 & 1,314 & 1,314 \\
Maintenance Costs & 1,110 & 1,325 & 930 & 1,175 \\
\hline
\end{tabular}

NOTE: Output, operator cost, and maintenance cost are on an annual basis. 
The cost of energy produced by the various systems is presented in Tables $\underline{6}$ and $\underline{7}$. A11 owner financed systems produce energy that is less than the present cost of propane or fuel oil. Systems that discount labor are less than or equal to the cost of natural gas in many areas of the country. Figure 27 compares costs of various fuels available to farmers with costs of bio-gas produced from anaerobic digesters and "synthetic fuels."

The cost of electricity produced is presented in Table $\underline{7}$. All farmer financed systems produce electricity for less than $\$ .055 / \mathrm{kwH}$. These systems are already cost competitive in some areas of the country. In the case of utility financed systems, the costs are somewhat higher. Although the larger scale plants would provide competitive electricity, when compared with the rising cost of energy produced from new thermal plants $(\$ .060 / \mathrm{kwH})$, the rate of return allowed the utility significantly increases the energy costs.

This suggests that perhaps a farmer-owned digester producing energy is the most cost effective overal1. Certainly, the farmer is given the opportunity to profit over the utility. If the farmer insists on a rate of return similar to the utility, then very likely the "cost" of the energy leaving the farm would be similar. The energy costs in Table $\underline{q}$ do not include this profit, but rather provide the "break even" cost for the farmer. Since the farmer also accrues benefits other than energy, a "break even" selling price is peasonable since that price pays for all costs, thus the remaining benefits are free.

The analysis takes into account current incentives available for this type of investment. The impact of these incentives, however, is not great.

Recent federal legislation has been proposed that would provide low interest loans to finance the purchase of solar technologies. Some versions of the legislations provide interest subsidies of up to $6 \%$ less than the current interest rates. To assess the impact of this financial incentive on the economics of digestion, a 200-head packaged system was evaluated at a range of interest rates from $6 \%$ to 12\% (Figure 28). 'lhe impact of this sort of incentive program over simple capital or tax credits is considerable.

Anaerobic digestion has often been considered to be of minor importance as an energy source because of the relatively small amount of manure that can be digested to make energy as compared to the energy needs of this country. Quantity 
Table 6: $\quad$ Cost of Gas for Farm Scale Anaerobic Digestion Systems in \$ per Giga Joule

200 Head Systems

Owner Financed Utility Financed

with labor without labor with labor

Packaged Systems with

manure handling

$\$ 5.21 \quad \$ 3.75 \quad \$ 7.55$

Packaged Systems without manure handling
4.26
3.38
6.08

Site-built System with manure handling

$4.77 \quad 3.30$

Site-built without

manure handling

3.55

2.67

400 Head Systems

Owner Financed

Utility Financed

with labnr without labor with labor

Packaged System with

manurc handling

$\$ 404 \quad \$ 2.94 \quad \$ 5.75$

Packaged system withour manure handling

3.23

2.56

4.90 
Table 7: Cost of Electricity for Farm Scale Digestion Systems in \$ per Kilowatt Hour

200 Head Systems

Owner Financed Utility Financed

with labor without labor with labor

Packaged Systems with

manure handling

$\$ .054$

$\$ .039$

$\$ .081$

Packaged Systems without

manure handling

$.045 \quad .036 \quad .064$

Site-built with manure handling

$.050 \quad .034$

Site-built without manure handling

$.042 \quad .032$

400 Head System

Owner Financing

Utility Financing

with 1abor without labor

with 1abor

Packaged Systems with

manure handling

$\$ .045$

$\$ .031$

$\$ .064$

Packaged System without

manure handling

$\begin{array}{lll}.036 & .028 & .055\end{array}$




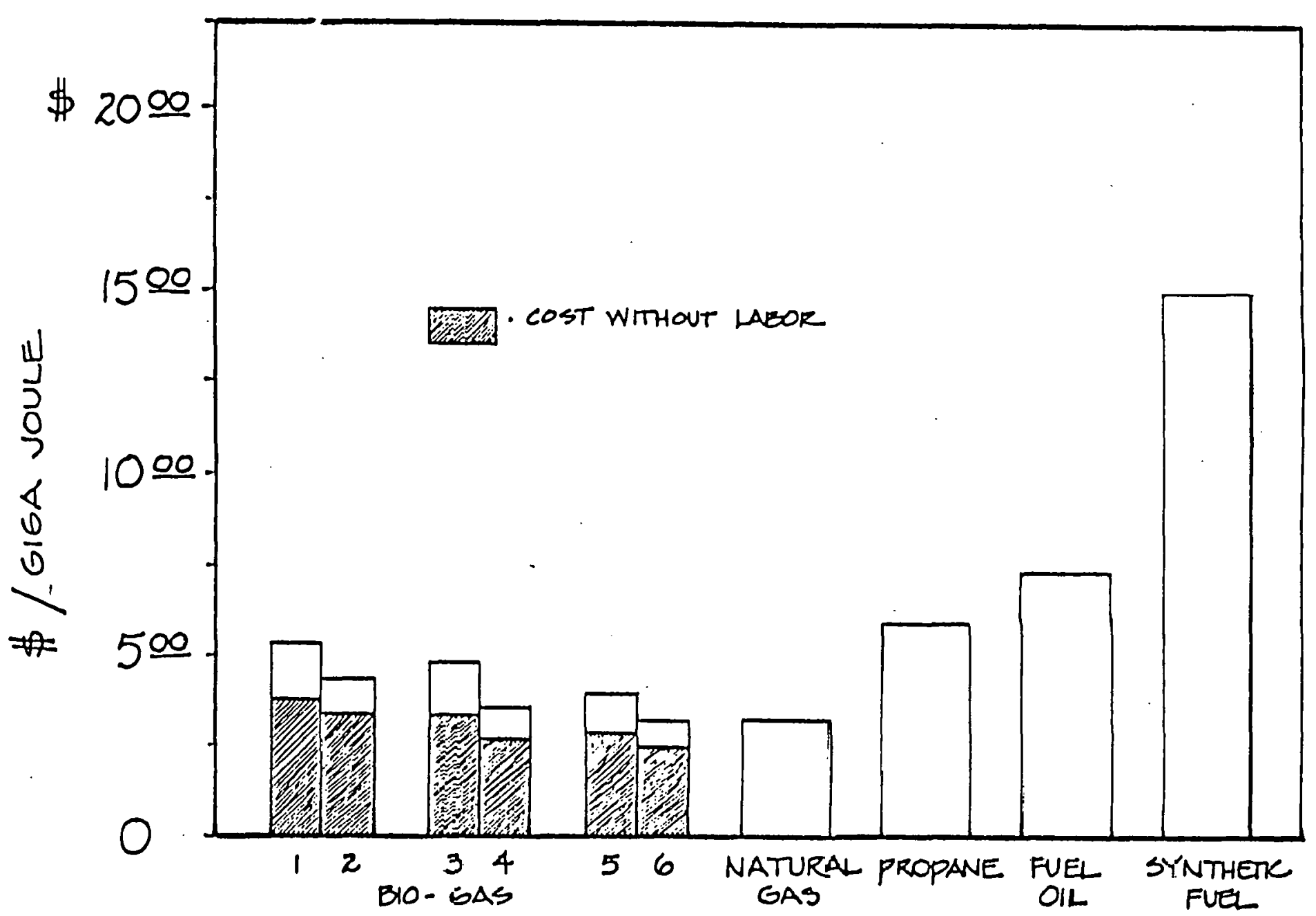

Figure 27- Cost Comparison of Various Fuels

1) Packaged systems with manure handling 200 Head 2) Packaged systems without manure handling Systens 3) Site-built systems with manure handling

4) Site-built systems without manure handling

400 Head 1) Packaged systems w:th manure handling Systens 2) Packaged systems without manure handling 


\section{EFFECT OF VARYING INTEREST RATE \\ ON COST OF ENERGY FROM A \\ 200 HEAD DAIRY FARM}

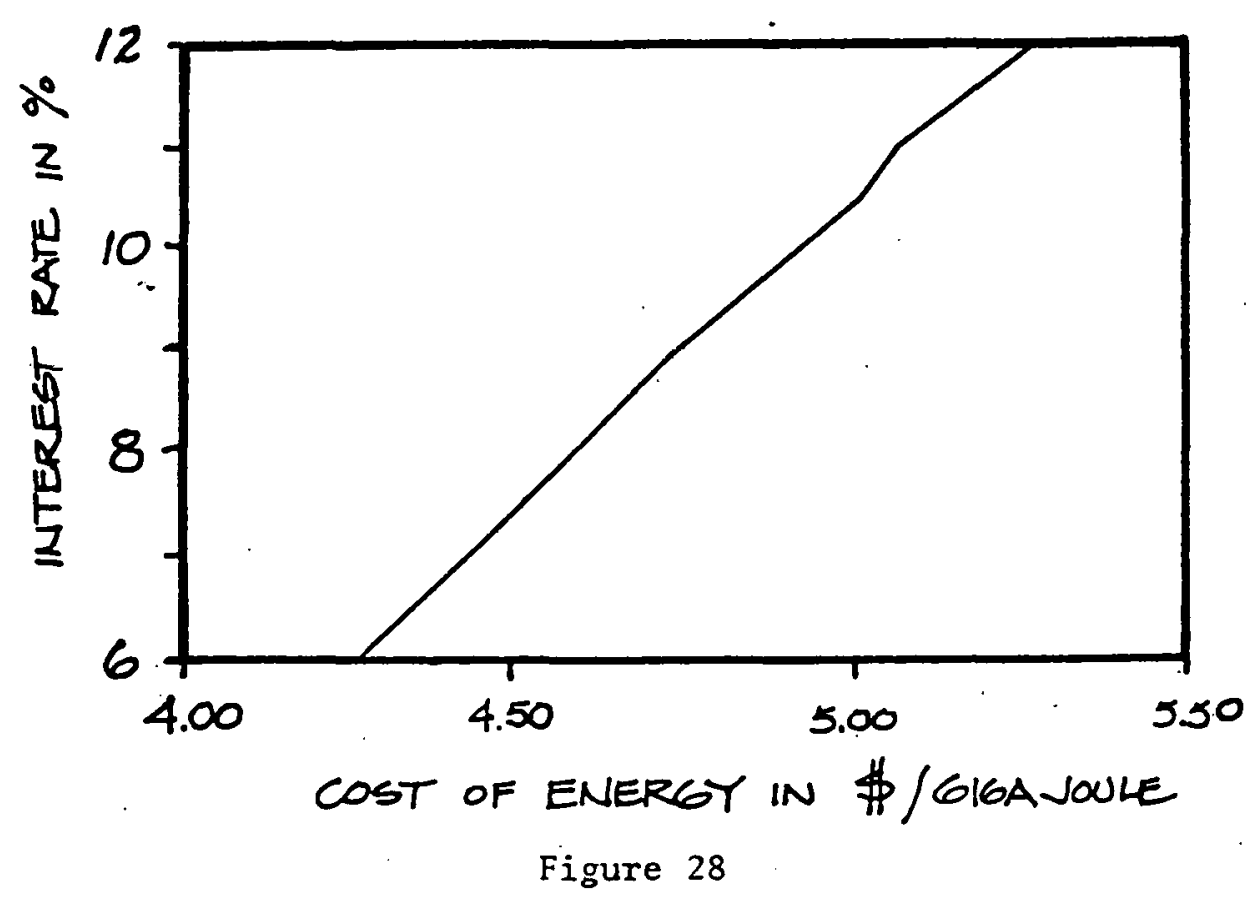

is, however, not the only criteria by which an energy source should be judged. This analysis demonstrates that the energy produced by anaerobic digestion is competitive with present energy costs and with the utility's marginal cost of production. With any decentralized technology, this should be the primary criteria for evaluation, not its overall impact, for there are many technologies that produce only a small percentage of our national energy needs at competitive costs. Individually, the technologies are of little consequence, but collectively they form the basis for a national energy independence that is within our means. Anaerobic digestion can make our dairies and feedlots significantly less dependent on fossil fuels and net energy producers. This would be an important step in the development of an agriculture that is increasingly less vulnerable to the uncertainties of our current energy supply and to the devastating inflation rate associated with that supply. 
APPENDIX I

Calculation of the Slurry-side Film Coefficient of the Draft Tube Heat Exchanger

I. Calculation of the overall heat transfer coefficient

A. Rate of heat transfer (Q)

$\mathrm{Q}=\mathrm{mCp} \Delta \mathrm{T}$

Where $M=437 \mathrm{lbm} / \mathrm{min}$

$$
\begin{aligned}
& \mathrm{Cp}=0.999 \mathrm{Btu} / 1 \mathrm{bm}-{ }^{\circ} \mathrm{F} \\
& \mathrm{AT}_{\mathrm{H}_{2} \mathrm{O}}=4.5^{\circ} \mathrm{F} \\
& \mathrm{T}_{\mathrm{H}_{2} \mathrm{O}}=120^{\circ} \mathrm{F}
\end{aligned}
$$

$Q=1965 \mathrm{Btu} / \mathrm{min}$

Where $D_{2}=34$ in.

$\mathrm{D}_{1}+30 \mathrm{in}$.

$A=45.4 \mathrm{ft}^{2}$

C. Overal1 heat transfer coefficient

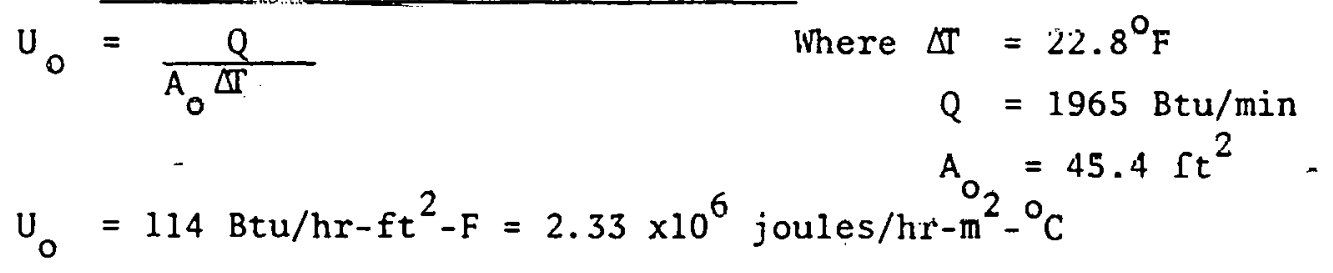

II. Calculation of the water side film coefficient

A. Calculate the Reynold's number

$\operatorname{Re}=\frac{4 m}{\pi D_{H} U}$

B. Calculate the Prandt l number

$$
\begin{array}{ll}
\operatorname{Pr}=\frac{\mathrm{CpU}}{\mathrm{k}} \quad \begin{aligned}
\text { Where } \mathrm{Cp} & =0.999 \mathrm{Btu} / 1 \mathrm{bm}-{ }^{\circ} \mathrm{F} \\
\mathrm{U} & =0.62 \mathrm{Cp} \\
\mathrm{k} & =0.372 \mathrm{Btu} / \mathrm{hr}-\mathrm{ft}-{ }^{\circ} \mathrm{F}
\end{aligned} \\
\operatorname{Pr}=4.03
\end{array}
$$

$$
\begin{aligned}
& \text { Where } M=4371 \mathrm{bm} / \mathrm{min} \\
& D_{H}=0.33 \mathrm{ft} \\
& U=0.62 \mathrm{c} p \\
& T_{\mathrm{H}_{2} \mathrm{O}}=120^{\circ} \mathrm{F}
\end{aligned}
$$


C. Calculate the water-side coefficient

$h_{i} D_{H}=0.023(R e)^{0.8} \operatorname{Pr}^{0.33} \quad$ Where $\operatorname{Re}=66778$

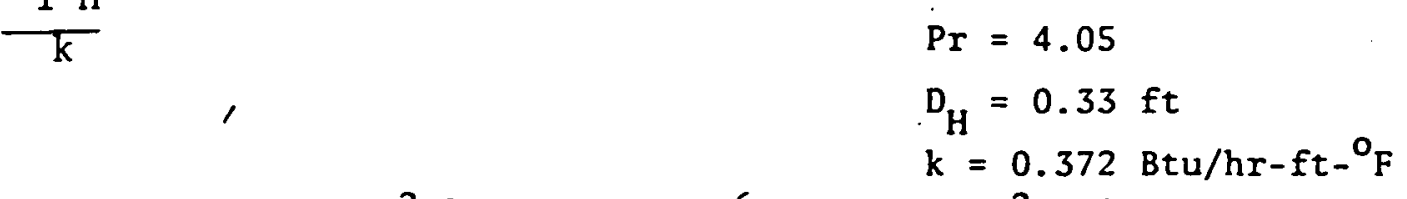

$h_{i}=296 \mathrm{Btu} / \mathrm{hr}-\mathrm{ft}{ }^{2}-{ }^{\circ} \mathrm{F}=6.05 \times 10^{6}$ joules $/ \mathrm{hr}-\mathrm{m}^{2}-{ }^{\circ} \mathrm{C}$

III. Calculation of the slurry-side film coefficient

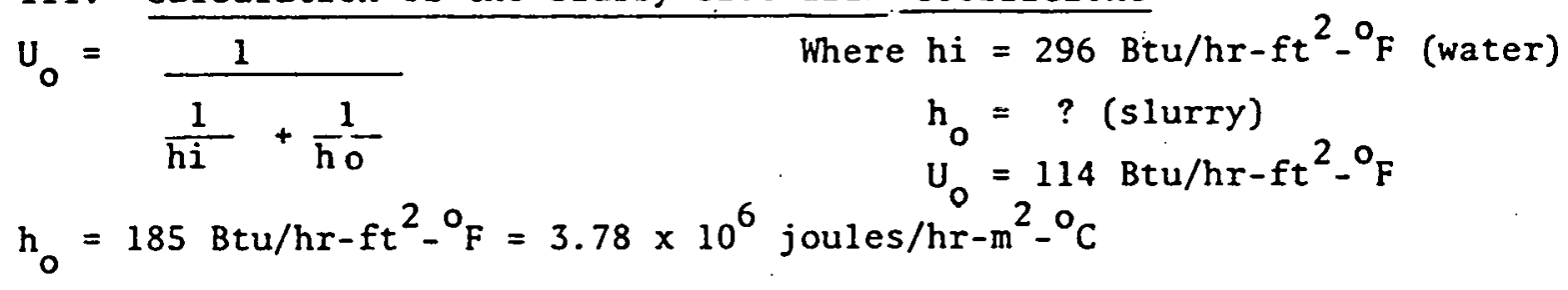




\section{APPENDIX II}

\section{COMPARTIVE SOLAR ECONOMICS-}

REAL COST COMPARISON

\author{
David Baylon \\ Ecotope Group \\ 2332 E. Madison \\ Searte, Wh 98112
}

Bruce O'Halloran

C.P.A.
ABSTRACT

The basis of solar econowies is diseussed in the context of four technologies. Passive/hybrid solar heating in new and remodel application, solar hot rater heating, active solar heating. and anaeroble digestion are compared on payback periods. rate of return, and the cost of energy generated/ sared by these teehnologies. A life cycle analysis will farn the basis nf the copparison, which ineludes operating date as the basis for the life eyele assumptions. The capiral costs, operation costs, and asineenance costs vill be considered, as well as fuel escalacion and inflation.

The output frov this analysis will be compared to the present and future marginal cost of energy produced from conventional "energy sources such as oil and electricity. and an evaluation of cast of the various energy production options including solar-based renewable technologies will be included.

\section{SUMuRY}

The developpent of solat energy as a viable energy producing rechnolocy has progressed considerably in the last 10 years. The source of this progress has not. however, been essentislly technological developaent. The flat place collector was developed 70 years ago, and its adaption to air heat collection is over 30 years old. Passive systeas were developed by the Greeks and Romans, and wile they were imored until faitly recently, they hardly qualify as the "legitiante technical breakthrough that nakes solar enerpy feasible." In fact, no such breakehrough has occurred.

Why are we then cold after decade of tinkering that solax enerby is feasible when te was 25 years away, only three years agot The reason, of course, is econonics. Solar energy is no longer a politicsl stepehild, but rather the legitinate heir to the energy supplies of the future: The butt le over the legitiancy of solar was not won in the laboratory, it ws on by accouncants and sestisticians. whose gethods are the real story of the solar breakthrough.

It is the purpose of this paper to describe two enalghicl approaches to energy econobics:

1) Consumer econovics - the prevailing visdon in solar economics based on solur enerp as consumer invescaent

2) Ueility tconowics - on analysis in which solar enex $2 y$ is compered to other actlids of producing and delivering the energy necessary to perfor the functions of the society.

\section{CONSUER ECONOMICS}

The essential assumption of this analysis is that the econonics of solar energ can to sumerised by the cost of the technology ro its ulrimate consumer. In this case, the assumption is that the consumer investment ill be based on the long-ter enerb costs of the other energy sources that wighe reet the need for fuel. This is flawed reasoning. for a consumer investment decision is not based on the rate of return, payback period, or life cycle econonics of that particular investaent. In fact, té If anj cunsumer investwents are based on such long-tera considerations. The initial cost has dowinated consuber dectsions, and at best - vague knowledge of the life-cyele performance is ineluded.

Nevertheless, the use of this analysis is instructive in dealing with design decislons for specifie clients, and in providing consumer-oriented pleture of a systers econonics ro the consumer. This should not be cuntrasted with the value of the solar systed in its larger ceonomic and social concext. The important coneepts here center on the intergelationship between capital coses annualized over the life of the investment. and annusl fuel costs for the energy source being replaced. These cost sereams are todified by three iaportant factors: interest or discount rates, inflation razes, and fuel cost escalation rates. Given that these are constant over the life of the investment, and that the fuel escalation rate is larter enan the inflation raze. two eurves can be dram (ser fig. 1). In this case capital costs are assuned to be annualized by a mortgage payment formula:

$$
\text { NP. ce }\left(\frac{i}{1-(1 \cdot i)^{-1}}\right)
$$

This is then nodified by correcting for inflation, to wit:

$$
T P=N \cdot \sum_{i=1}^{N}\left(\frac{1+e}{1+T}\right)^{-1}
$$

Incegrating with respect to $i$ where $r$ is consiant, and not equal to 0:

$$
T P=A P \cdot \frac{1-(1+r)^{-N}}{T}
$$

When equetion 3 is solved for the 1 ifo of the investuens, TP is the rotal capital cost over that $I$ ife, and thus the area under the capital cost curve in Fig. 1. The fuel cosi curve is conpuled at:

$$
\pi=A F \cdot \sum_{i=1}^{N}\left(\frac{1+e}{1+r}\right)^{i}
$$

Incegrating with respect to i (where $f(r)$ :

$$
T F=N F=\frac{\left(\frac{1+e}{1+T}\right)^{N}-1}{\ln \left(\frac{1-5}{1+T}\right)}
$$

Equation $S$ is the equartion for the area under the effective fuel cost curve correcting for inflation and fuel cost escalation in Fig. 1 . 
Fron these two lines various situations can be computed; the most of ten used is the payback. This is defined as the year in which the area under the fuel cost curve and the area under the capital cost curve are equal. By solving for this point the equation becomes:

$$
K=\frac{\ln \left[( \frac { 1 } { s } ) \operatorname { l n } ( \frac { 1 + C } { 1 + r } ) c c \left(\frac{i}{\left.\left.1-(1+i)^{-x}\right)\left(\frac{1-(1+r)^{-N}}{\ln (1+r)}\right)+1\right\}}\right.\right.}{\ln \left(\frac{1+e}{1+r}\right)}
$$

A second statistic is the rats of return. This is defined as the average economic returil on invested capital over the life of the investment:

$$
M=\left(\frac{T F-C}{T P}\right)^{\frac{1}{N}}-1
$$

Simply: the total benefits minus operation costs over the total capital invested. If the computations of TF $\&$ TP are corrected for inflacion then $M$ is the real rate of return above inflation, and $1 / N$ averages the rate of return over the entire life. Properly then, the rate of return is computed as the average difference per year between the areas under the two curves.

\section{UTILITY ECONOMICS}

The use of utility economics brings one additional dimension to the analysis. By this method the figures can compure the average cost of the energy produced over the life cycle of the technology: This computation is somewhat simpler in that only the capital cost curve is relevant. Utilities allow two sorts of capital costs, the first a rate of return or profit on their invested capital (equity), and the second. cost of the capital borrowed (debt). These two rates are substantially different, and indeed over the life of the investment the ratio of equity to debt will change. (Seigal, et al, 1972.) of course, the utility is constantly investing and borrowing. and for the whole system this ratio remains relatively constant. So for simplicity's sake only one rate will be used. The integral of the annual capital cost would then be:

$$
T P=\operatorname{cc}\left[\left(\frac{1-(1+T)^{-N}}{\ln (1+r)}\right) i+1\right]
$$

where the annual rate of return is.paid each year for the iife but devalued by inflation over time. If the curve for the consumer investment is used then the cost of energy is simply the total cose compuced in equation 3 . The cost of energy is then the total cost divided by the energy produced over the life, or:

$$
\operatorname{COE}=\frac{\mathrm{TC}+\mathrm{C}}{\mathrm{E}}
$$

The difference between calculating TC by equation 8 over equation 3 is that equation 8 will tell you how much the utility would charge if they could own the energy, and equation 3 is the actual cost to the consumer. It is not surprising that the utility method roughly doubles the total capital cost.

\section{COMPARATIVE SOLAR ECONOMICS}

The economics of all solar installations contain uncertainties associated with any consuiter technology that provides a number of tangible and intangible benefits

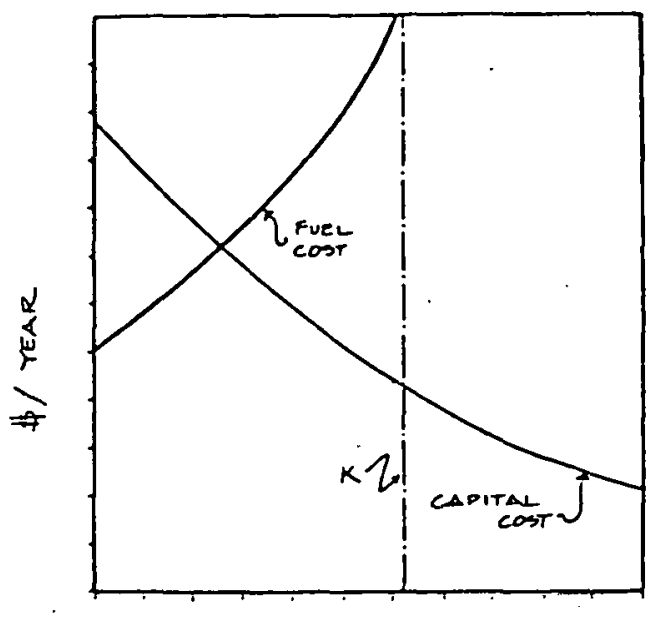

YEARS

Fig. 1

to its owner, in addition to its energy production capabilities. The consumer must consider these benefits in any design to maximize the benefits from the system. This analysis conservatively ignores the benefits other than direct economic benefits of alternative energ) production. It evaluates the economic benefits of conservation, passive solar, active solar, and anaerobic digesters.

Conservation. provides unquantified benefies of nore comfortable indoor temperatures free of drafts, and the satisfaction of personal contribution to local and national energy independence. Some of these benefits for passive systems include: beter indoor' 2 ighting. a feel ing of spaciousness, potential for indoor food production, usually more comfortable indoor temperatures, the lack of drafts caused by many forced-air systems, and the satisfaction of obtaining greater energy independence. Anaerobic digesters provide benefles of odor reduction, water pollution control. integrated manure handling. fertilizer production. and greater self-sufficiency. The value of these benefits varies between individuals, site locations, and specific system designs. An individual considering investment in these technologies wust carefully evaluate these benefits in addition to evaluating the economic benefits of the syster.

The economic benefits of systems are al so not easily quantified because a proper economic analysis of this technology that produces or saves energy for an individual consumer must assess the future costs of the alternative energy sources such as fossil fuels and elertricity. One expects these costs to rise by an undetermined amount. wich is affected by the relative impact of general inflationary cost escalations. This analysis provides payback and present value analysis data based upon projections into the future that may or may not match future events.

The application of this methodology is presented in Table 1. The cases presented are 1) a solar house built in Ednonds. WA (Ecotope Group, 1977); 2) a proposed solar retodel in Seattle, WA (Baylon, et al, 1978); and 3) the wethane digester built in Monroe, NA (Coppinger, et al, 1978). The assumptions for computing this table are in Table 2. 
Table 2. COHPARATIVE ECONOMICS FOR SELECTED SOLAR TECHNOLOCIES

\begin{tabular}{|c|c|c|c|c|c|c|c|c|c|}
\hline \multirow[b]{2}{*}{$\begin{array}{l}\text { Capital } \\
\text { Cost } \\
\text { (s) }\end{array}$} & \multirow[b]{2}{*}{$\begin{array}{l}\text { Erergy } \\
\text { Savings } \\
\text { (MBTUS) }\end{array}$} & \multirow[b]{2}{*}{$\begin{array}{l}\text { Energy } \\
\text { Savings } \\
\text { ( }) \text { (average) }\end{array}$} & \multicolumn{4}{|c|}{ CONSLAER } & & \multicolumn{2}{|c|}{ UTILIT } \\
\hline & & & $\begin{array}{l}\text { Energy } \\
\text { Savings } \\
\text { (s) } \\
\text { (marginal) }\end{array}$ & $\begin{array}{l}\text { Payback } \\
\text { Yoars }\end{array}$ & $\begin{array}{l}\text { Rote } \\
\text { of } \\
\text { Return } \\
\text { laverage }\end{array}$ & $\begin{array}{l}\text { Credits } \\
\text { e) }\end{array}$ & $\begin{array}{l}\text { Cost } \\
\text { of } \\
\text { Energy }\end{array}$ & Credits & $\begin{array}{l}\text { Cos: } \\
\text { o! } \\
\text { Energy }\end{array}$ \\
\hline
\end{tabular}

CASE I

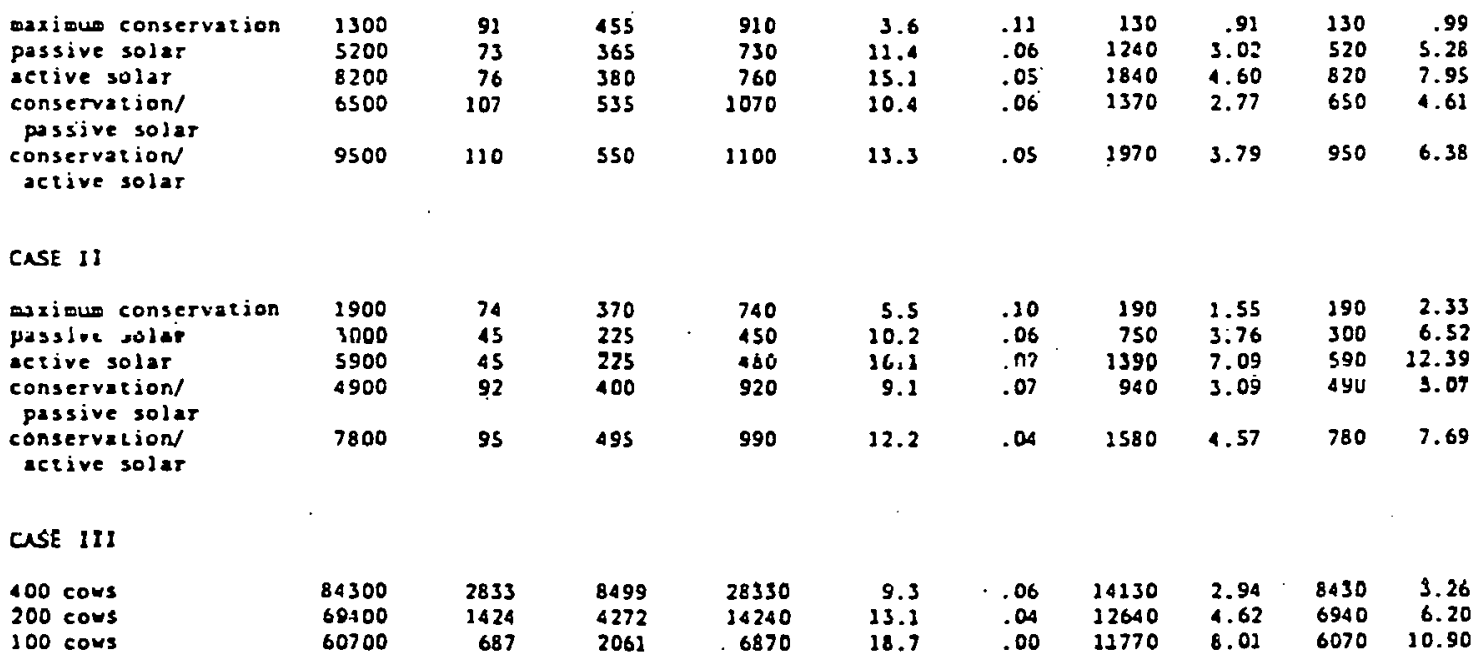

The consumer investoents analysis uses those credits available to a consuser such as the solat tax credils. wile the utility anajysis uses only the 100 investment tax credits. The cost of energy to the consuber is based on a life cycle cost. with no residual value it the completion of the investecne's oconnaic life. This is probably not true, especially in the case of a new house with a passive system. The systo could be expected ro lase (and save energy) for as long as the house, which should be at least twice as long as the 'econonic life' of the Dortgage.

The urjlity ecofowics presented also arsuge nn residual wlue: hoverer. This is less severe in that the utilizy an be asked to turn its invesiment over tu the burister after it has received its rate of rexurn for the 'econodic life.' Table 3 provides the relevane cost comparison for urility financing.

In general. with addition of rax credits for solar and conservation investeents, the payback periods and rato of return becone quite arcractive, even for relatively expensive oprions. The cost of pacive salat oprion for a new house is t.'T \$2.77/ABTUs saved, atout 601 of the current cost of energ: tn the consumer, This of course ignores other econoajc benefits and the increaste in tne howe's luiri-rore marker value.

Active solar systems are somewhat more expensive, but with credits they reain an atrractive investment when compared to long-teri energy costs Buth efeivo and passive systegs when combined in a roral energy package for a hoae yzeld cost-effective energy savings, with payback periods

substantially belor the life of the mortgage. Hovever. since wost howeomers move vithin six years. the fessibility of cost of these options depends on the increase on tho sale price of the howe or sowe further subsidy to aske this cost-effective investent also actractive to the avorago noneomet. Thls suggesls that since the energy saving bane- fits accruing to the whole society that are not necessarily atractive to an individual. For this reason the urility and irs ceonomic benefits must be considered as visble oprion.

In Case III the anserobic dipeszer coiparisons illustrate the oeonowieg of scale associated with this technology. Here when comparod ro current gas costs, econowic scale might be about 200 cows; when compared co marginsl cosis oven a very sall digester of this eype would be economically feasible at the margin.

Table 2. ASSLAPTIONS FOR LIFE CYCLE AMLYSIS

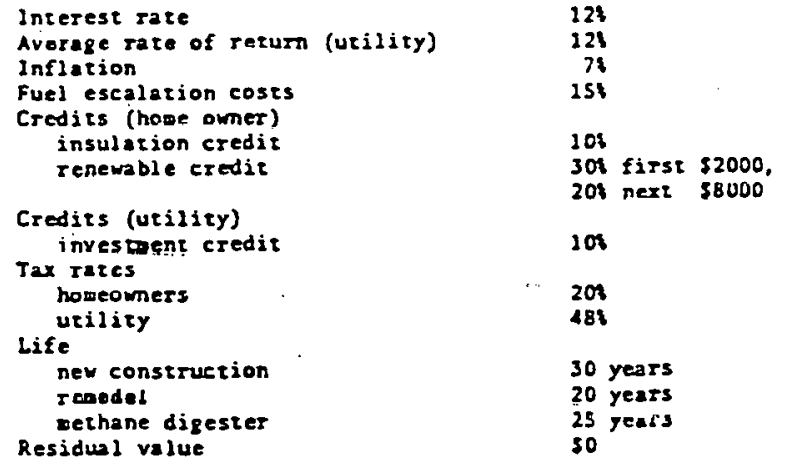




\section{SOUR ENERCY FOR ENERCY PRODUCTION}

Wh-- the life cycle costs of solar energy are computed on an dual basis. the economics are attractive. The issuo, r. is not solar energy as consumer investeent, but its economic standing when compared with the alternate vys to ecquire the next units of energy. Tho cost of these units is known is marginal cost.

In the case of electricity. for example, the rginal cost is the cost of electricity from the new thermal plants (currently estimated at \$12/MBTU and elimbing). This cost is not seen by the conswer: it is seen by the utllity. These costs are summirized in Table 3 . When the future cost of conventional energy sources is compared with the life cycle cost of energy produced with an investent in solar resources. It becoacs apparent that at the margin tho wost cost-effective investwents are in solar energy and in conservation applied to the individual home.

Table 3. UTILITY FINANCINC ( $\$ / M B T U S$ )

\begin{tabular}{|c|c|c|c|c|c|}
\hline (average) & 1950 & 1960 & 1970 & 1980 & $\begin{array}{l}\text { margin } \\
\text { (1979) }\end{array}$ \\
\hline $\begin{array}{l}\text { Fuel Cost } \\
\text { oil } \\
\text { gas } \\
\text { edecericity }\end{array}$ & $\begin{array}{l}1.50 \\
4.50\end{array}$ & $\begin{array}{l}1.50 \\
1.00 \\
4.00\end{array}$ & $\begin{array}{l}1.50 \\
1.20 \\
2.50\end{array}$ & $\begin{array}{r}10.00 \\
9.00 \\
5.00\end{array}$ & $\begin{array}{l}12.00 \\
10.80 \\
16.30\end{array}$ \\
\hline Conservation & & & & $1-2.50$ & 2.50 \\
\hline $\begin{array}{l}\text { Solar } \\
\text { passive } \\
\text { active } \\
\text { hot vater }\end{array}$ & & & & $\begin{array}{l}5-7.50 \\
8-12.00 \\
5-10.50\end{array}$ & $\begin{array}{r}7.50 \\
12.00 \\
10.50\end{array}$ \\
\hline $\begin{array}{l}\text { Anacrobic Dig } \\
400 \text { cous } \\
200 \text { cous } \\
100 \text { cous }\end{array}$ & gesti & & & & $\begin{array}{r}3.20 \\
6.20 \\
10.90\end{array}$ \\
\hline
\end{tabular}

The irony here is that utilities have access to capital to invest in new energy supplies. Indeed, utilities are generally betcer able to raise capital than even large corporations, but that capital in the past has been comaited. to large plants with huge capizal requirements. This amalysis dewonstrates that, taking all choices into consideration, the utility's best choice is not a coal plant. a nuelear plant, a coal gasification unit, or tho oil sport earket, but rather the energy that could bo produced at their customers own hones. This is tho central challenge of solar energy, and it will cause some very fundabental changes in the institutions that have deliverad energy in the past. The use of utilities 25 aechanisas to purchase solar energy independence for our howes aust be considered the top priority.

Through this wechaniso a sufficient amount of energy wold he savd, and thc neel for new purchases at the margin clioinated. This would bring about the real 'breakthrough' in solar energy.

\section{List of symbols}

cc: initial capital cost of the investment

1: interest rate/rate of return

inflation rate

fuel cose estalarion rate

econonic life of the investrent

anmual pareene on the investment

sul of all annual payents over the ilfe, converted for inflation

cost of annual fuel saved/produced for competitive fuels
TF: total savings over the econowie life

$x$ : payback year

C: total cost of operation, the investment over the llfe

H: Tate of return to the consumer

$E$ : local energy produced/saved over the economic life (BTUS, KWH, ote.)

COE: average cost of the produced/savel energy over the economic life of the investment

\section{References}

Baylon, et al, 1978. Solar/Conservation Remodel Candidares for Seartle City light. Ecotope Group, Seatrle, Ma

Coppinger, et al, 1978. Roport on the Design and First Year Operation of 50,000 Callon Anaerobic Digester. Ecotope Group, Seatele, Wh

Ecorope Group, 1977. "Solar Energy in the Pacific Northwest," Bartelle Mesorial Insticute, Richland. M

Straub, et al, 1976. Feasibility of Solar Retrofit for the Black Residence. Ecotope Group, Seartle, HA

Seigal, et al, 1972. Description of Gas Cost Calculation Method Being Used by the Symthetic Cas-Coal Task Force of the F.P.C. National Gas Survey, ESSO Research and Engineering, hashington, D.C. 
S=PI 


\begin{tabular}{|c|c|c|}
\hline $\begin{array}{l}\text { Document Control } \\
\text { Page }\end{array}$ & $\begin{array}{l}\text { 1. SERI Report No. } \\
\text { TR-312-471 }\end{array}$ & 3. Recipient's Accession No: \\
\hline \multirow{2}{*}{\multicolumn{2}{|c|}{$\begin{array}{l}\text { 4. Title and Subtitle } \\
\text { Report on the Design and Operation of a Full-Scale } \\
\text { Anaerobic Dairy Manure Digester }\end{array}$}} & $\begin{array}{l}\text { 5. Publication Date } \\
\text { December } 1979\end{array}$ \\
\hline & & 6. \\
\hline \multicolumn{2}{|c|}{$\begin{array}{l}\text { Author(s) } \\
\text { Elizabeth Coppinger, Jack Brautigam, John Lenart, David }\end{array}$} & 8. Performing Organization Rept. No \\
\hline \multirow{2}{*}{\multicolumn{2}{|c|}{$\begin{array}{l}\text { 9. Performing Organization Name and Address } \\
\text { Ecotope Group } \\
2332 \text { East Madison } \\
\text { Seattle, Wash. } 98122\end{array}$}} & $\begin{array}{l}\text { 10. Project/Task/Work Unit No. } \\
3335.01\end{array}$ \\
\hline & & $\begin{array}{l}\text { 11. Contract (C) or Grant (G) No. } \\
\text { (C) } \\
\text { (G) }\end{array}$ \\
\hline \multicolumn{2}{|c|}{ 12. Sponsoring Organization Name and Address } & 13. Type of Report \& Period Covered \\
\hline \multirow{2}{*}{\multicolumn{2}{|c|}{$\begin{array}{l}\text { Solar Energy Research Institue } \\
1617 \text { Cole Blvd. } \\
\text { Golden, Colo. }\end{array}$}} & Final Technical Report \\
\hline & & 14. \\
\hline
\end{tabular}

15. Supplementary Notes

16 Abstract (Limit: 200 words)

A full-scale anaerobic digester on the Monroe State Dairy Farm was operated and monitored for 24 months with funding provided by the United States Department of Energy, Fuels from Biomass Systems Branch. During the period of operation, operating parameters were varied and the impact of those changes is described. Operational experiences and system component performance are discussed. Internal digester mixing equipment was found to be unnecessary, and data supporting this conclusion are given. An influent/effluent heat exchanger was installed and tested, and results of the tests are included. Recommendations for digester design and operation are presented. Biological stability was monitored, and test results are given. Gas production rates and system net energy are analyzed. The economics of anaerobic digestion are evaluated based on various financing options, design scales, and expected benefits. Under many circumstances digesters are feasible today, and a means of analys is is given.

17. Document Analysis

a. Descriptors Anaerobic Digestion ; Demonstration Programs ; Dairy Industry ; Design ; Operation ; Testing ; Washington

b. Identifiers/Open-Ended Terms State Honor Farm, Monrüe, Washington

c. UC Categories

$\mathrm{UC}-61$

18. Availability Statement

National Technical Information Service

U.5. Department of Commerce

5285 Port Royal Road

Springfield, Virginia 22161 